\title{
Gradient and recurrence analyses of four marine zones in the Glenshaw Formation (Upper Pennsylvanian, Appalachian Basin)
}

Joseph G. Lebold

West Virginia University

Follow this and additional works at: https://researchrepository.wvu.edu/etd

\section{Recommended Citation}

Lebold, Joseph G., "Gradient and recurrence analyses of four marine zones in the Glenshaw Formation (Upper Pennsylvanian, Appalachian Basin)" (2005). Graduate Theses, Dissertations, and Problem Reports. 2245.

https://researchrepository.wvu.edu/etd/2245

This Dissertation is protected by copyright and/or related rights. It has been brought to you by the The Research Repository @ WVU with permission from the rights-holder(s). You are free to use this Dissertation in any way that is permitted by the copyright and related rights legislation that applies to your use. For other uses you must obtain permission from the rights-holder(s) directly, unless additional rights are indicated by a Creative Commons license in the record and/ or on the work itself. This Dissertation has been accepted for inclusion in WVU Graduate Theses, Dissertations, and Problem Reports collection by an authorized administrator of The Research Repository @ WVU.

For more information, please contact researchrepository@mail.wvu.edu. 
Gradient and Recurrence Analyses of Four Marine Zones in the Glenshaw Formation (Upper Pennsylvanian, Appalachian Basin)

\author{
Joseph G. Lebold
}
Dissertation submitted to the Eberly College of Arts and Sciences at West Virginia University in partial fulfillment of the requirements for the degree of Doctor of Philosophy in Geology

\author{
Thomas Kammer, Ph.D., Chair \\ William Ausich, Ph.D. \\ Helen Lang, Ph.D. \\ Ronald Martino, Ph.D. \\ Richard Smosna, Ph.D. \\ Department of Geology and Geography \\ Morgantown, West Virginia \\ 2005
}

Keywords: Paleoecology, Biofacies, Conemaugh Group, Faunal Tracking, Environmental Stability

Copyright 2005 Joseph G. Lebold 


\begin{abstract}
Gradient and Recurrence Analyses of Four Marine Zones in the Glenshaw Formation (Upper Pennsylvanian, Appalachian Basin)
\end{abstract}

Joseph G. Lebold

The Upper Pennsylvanian Glenshaw Formation contains a series of marine zones that were deposited on the detrital slope of the Appalachian highlands during the last major transgressions from the Midcontinent Sea in the Paleozoic of eastern North America. These marine zones contain distinctive fossil assemblages characterized as biofacies that inhabited a variety of shallow marine environments.

The first chapter of this paper focuses on the Ames marine zone sampled along a northwest-southeast transect across the Appalachian Basin. The Ames marine zone was deposited during the most extensive marine transgression of the Pennsylvanian in this region. Gradient analysis of the proportional abundance of taxa reveals an environmental continuum along which four biofacies were distributed. Biofacies distribution is interpreted to be controlled by salinity, turbidity, and oxygen gradients related to the proximity to eastern terrigenous source areas and relative sea-level change.

The stratigraphic range of this study is expanded in the second chapter and third chapters was expanded to include the Lower Brush Creek Upper Brush Creek and Cambridge marine zones. The geographic range is also expanded to include exposures in four separate geographic regions in the Appalachian Basin. Gradient analysis of the proportional abundance of taxa reveals an environmental continuum along which five biofacies were distributed. The distribution of the five biofacies along the gradient is interpreted to be controlled by the degree of environmental stability. The degree of environmental stability fluctuated during the establishment of marine faunas in the Glenshaw Formation due to the rate of relative sea level change, geographic position relative to the source of marine influence, geographic position relative to eastern terrigenous source areas, and the relative extent of the four marine incursions.

Biofacies within the Glenshaw Formation re-appear with a distinctive compositionabundance structure tracking a preferred set of environmental conditions. The eight most abundant genera were non-randomly distributed, indicating a consistent environmental preference. Only four of the remaining 15 less abundant genera were non-randomly distributed. The abundant taxa maintain a more consistent membership within biofacies by tracking their preferred environment. This pattern is consistent with an independent response of taxa to changing environmental conditions. 


\section{PREFACE - A Note on Organization}

The following doctoral dissertation was completed in the form of three articles ready for submission in peer reviewed journals, which is already underway. Because of this format, there is some repetition of introductory material in each paper and the tables and figures are placed at the end of each chapter. The references have been combined into a single list.

The papers are treated here as chapters and are referred to as such throughout this volume. The first chapter is a paleoecological study of the Ames marine zone sampled along a northwest-southeast transect across the Appalachian Basin. In the second chapter, the geographic and stratigraphic domain is expanded to include three other marine zones sampled in four separate geographic regions in the Appalachian Basin. The third chapter has the same geographic and stratigraphic domain as chapter 2 but the focus is on evolutionary patterns more than ecological patterns. 


\section{ACKNOWLEDGMENTS}

This research was supported by grants from Schlumberger, Inc., the Eberly College of Arts and Sciences, the Doctoral Assistance Program, and the Department of Geology and Geography at West Virginia University. Helpful field assistance and discussions were provided by Ron Martino, Marshall University, Greg Nadon, Ohio University, and John Harper, Pennsylvania Geologic Survey. Jon Harper also assisted in gastropod and bivalve identifications.

I would like to thank Dr. Gerry Hobbs in the Department of Statistics at West Virginia University and Dr. Robert Hanham of the Department of Geology and Geography at West Virginia University for their access to, and assistance regarding the SAS statistical software package. Tom Olszewski and Carl Brett provided helpful and constructive reviews to an earlier version of the first chapter. Lastly, I wish to thank Dr. Thomas Kammer, my Ph.D. advisor, whose helpful advice in the field, library, and lab, as well as manuscript editing, made a significant contribution to this research. 


\section{TABLE OF CONTENTS}

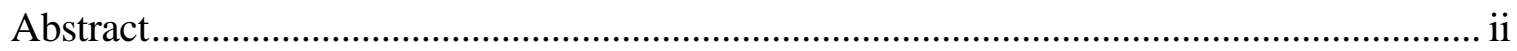

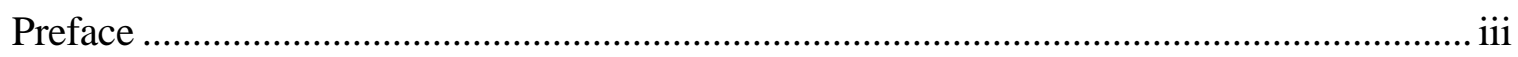

Acknowledgements .......................................................................................................... iv

1.0.0.0. Gradient analysis of faunal distributions associated with rapid transgression and low accommodation space in a Late Pennsylvanian marine embayment: Biofacies of the Ames Member (Glenshaw Formation, Conemaugh Group) in the northern Appalachian Basin, U.S.A....... 1

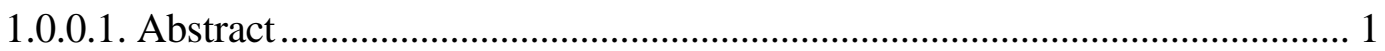

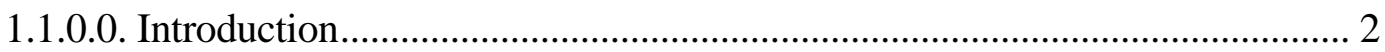

1.2.0.0. Stratigraphy and Geologic History ............................................................... 3

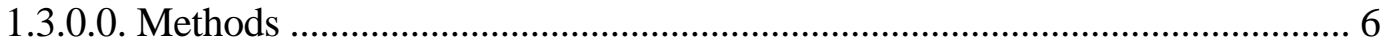

1.3.1.0. Outcrops and Samples .................................................................. 6

1.3.2.0. Guild Composition.......................................................................... 7

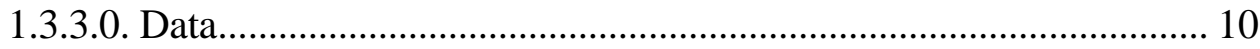

1.3.4.0. Multivariate Analysis ................................................................... 12

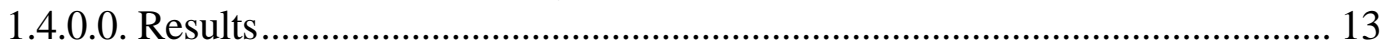

1.5.0.0. Biofacies Description and Environmental Interpretation............................... 15

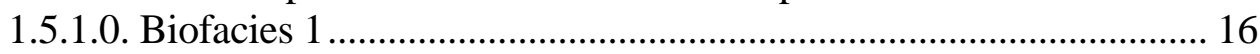

1.5.2.0. Biofacies 2 ………………………………………………... 17

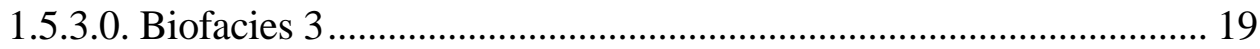

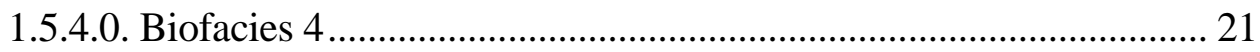

1.6.0.0. Biofacies Variation .................................................................................. 23

1.6.1.0. Lateral Variation .............................................................................. 23

1.6.2.0. Vertical Variation............................................................................ 25

1.6.2.1. Transgression 1 ..................................................................... 25

1.6.2.2. Regression 1 .......................................................................... 27

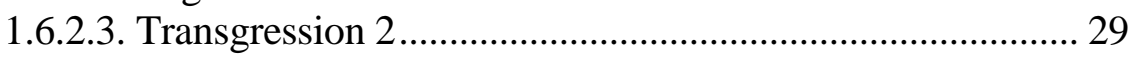

1.6.2.4. Regression 2...................................................................... 30

1.7.0.0. Oxygen Availability ..................................................................................... 31

1.8.0.0. Conclusions ............................................................................................... 33

2.0.0.0. Degree of environmental stability as a primary control on biotic distribution: Gradient analysis of four marine zones within the Glenshaw Formation (Conemaugh Group, Upper Pennsylvanian) in the Appalachian Basin..............................................................................53

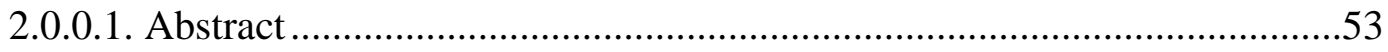

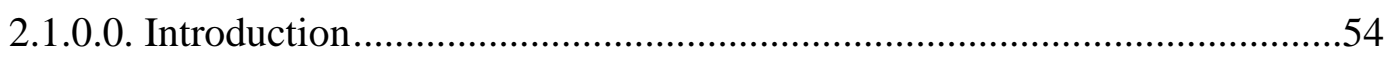

2.2.0.0. Stratigraphic and Geologic History ………….........................................55

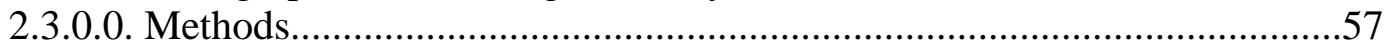

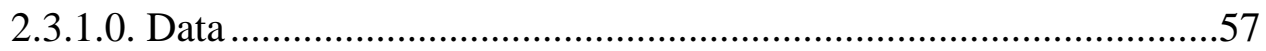


2.3.2.0. Gradient Analysis........................................................................60

2.3.3.0. Multivariate Analysis.................................................................61

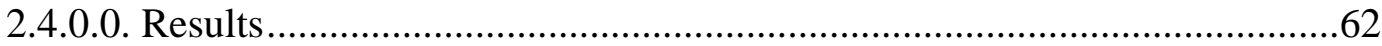

2.4.1.0. Faunal Patterns Within Glenshaw Marine Zones ..........................62

2.4.2.0. Glenshaw Biofacies ...................................................................65

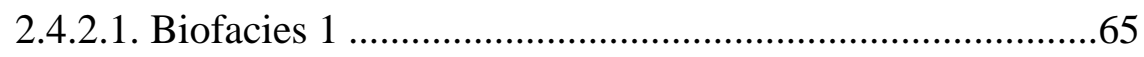

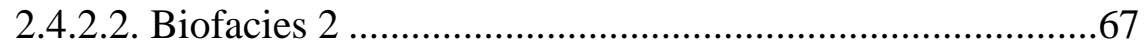

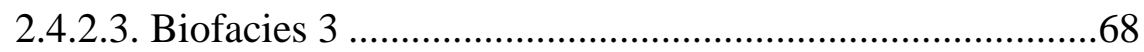

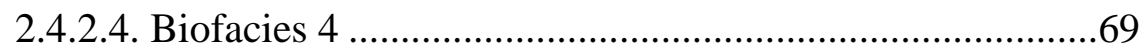

2.4.2.5. Biofacies 5 ......................................................................

2.5.0.0. Gradient Interpretation ..........................................................................

2.6.0.0. Regional Factors Affecting Environmental Stability................................75

2.6.1.0. Rapid Transgression.....................................................................75

2.6.2.0. Extent of Marine Transgression......................................................76

2.7.0.0. Localized Factors Affecting Biofacies Variation ........................................79

2.7.1.0. Southern Samples Gradient..........................................................80

2.7.2.0. Northern Samples Gradient...........................................................81

2.7.3.0. Eastern Samples Gradient .............................................................83

2.7.4.0. Western Samples Gradient............................................................85

2.8.0.0. Conclusions..............................................................................................86

3.0.0.0. Evidence for faunal tracking in recurrent fossil assemblages in four major marine zones in the Glenshaw Formation (Upper Pennsylvanian, Appalachian Basin)..........................106

3.0.0.1. Abstract ............................................................................................106

3.1.0.0. Introduction......................................................................................107

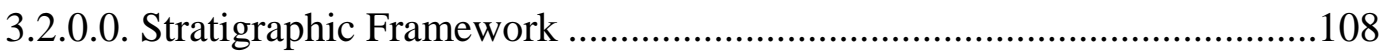

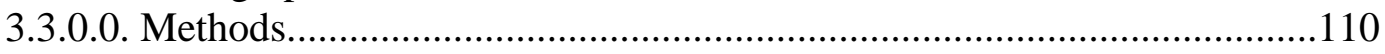

3.3.1.0. Samples and Data....................................................................110

3.3.2.0. Multivariate Analysis..............................................................112

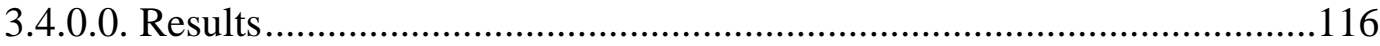

3.4.1.0. Classification and Discriminant Analysis...................................116

3.4.2.0. Recurrence Analysis ....................................................................119

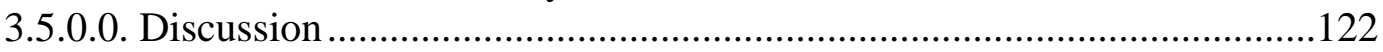

3.5.1.0. Environmental Interpretation ...................................................122

3.5.2.0. Recurrence and Faunal Tracking of Glenshaw Biofacies............126

3.5.3.0. Comparison to Related Studies..................................................131

3.6.0.0. Conclusions.............................................................................................133

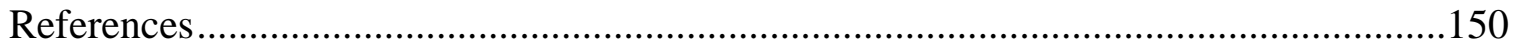

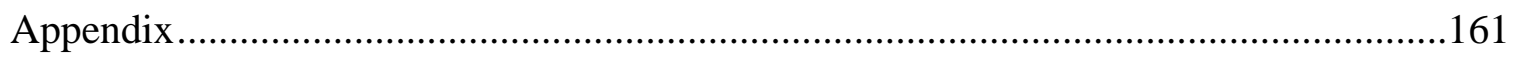

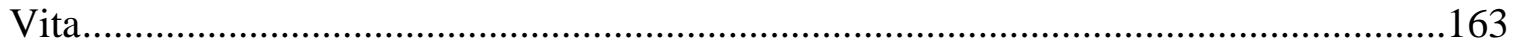




\section{LIST OF TABLES}

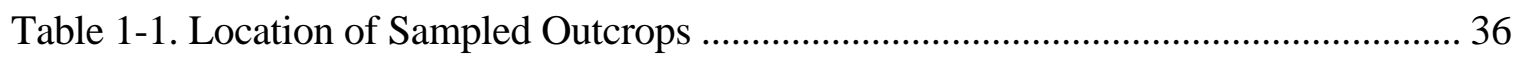

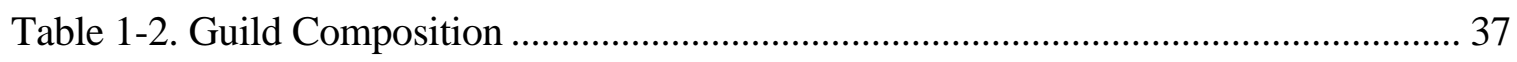

Table 1-3. Percent Abundance of Guilds and Sample Totals ........................................... 38

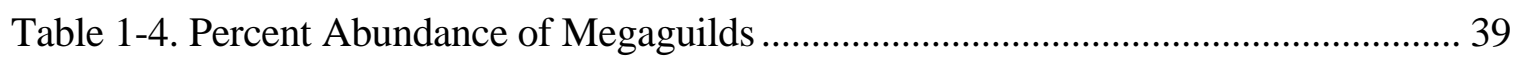

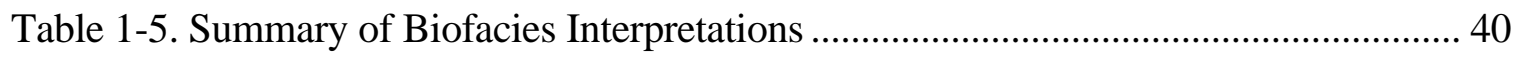

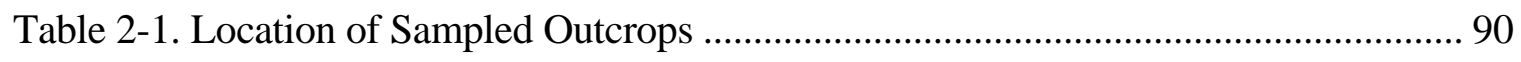

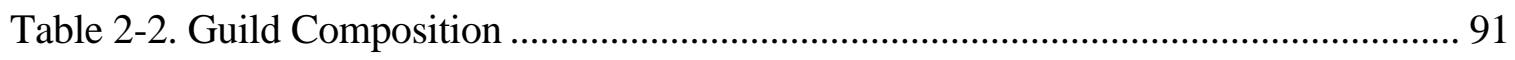

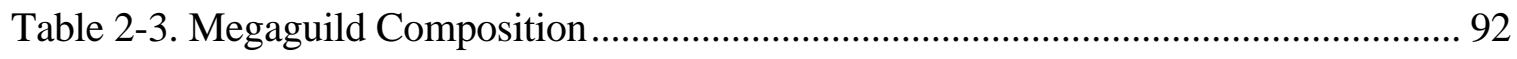

Table 2-4. Percent Abundance of Megaguilds ................................................................. 93

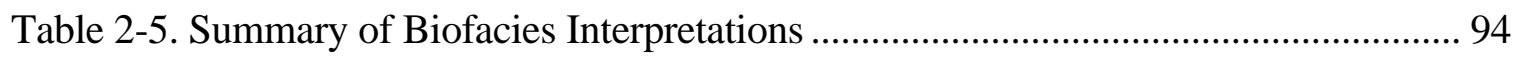

Table 3-1. Location of Sampled Outcrops ...................................................................... 135

Table 3-2. Data Set of Brachiopod, Bivalve, and Gastropods Genera .............................. 136

Table 3-3. Results of Discriminate Analysis ................................................................. 137

Table 3-4. Stratigraphic Distribution of Brachiopod, Bivalve, and Gastropod Biofacies . 138

Table 3-5. Mahalanobis Distances Between Biofacies Centroids .................................... 139

Table 3-6. MANOVA Tests of the Distance Between Biofacies Means ............................ 140

Table 3-7. Univariate F-Tests of Brachiopod, Bivalve, and Gastropods Genera................ 141 


\section{LIST OF FIGURES}

Figure 1-1. Outcrop Belt of the Conemaugh Group ....................................................... 41

Figure 1-2. Stratigraphic Column of the Conemaugh Group ............................................ 42

Figure 1-3. Late Pennsylvanian Paleogeography .............................................................. 43

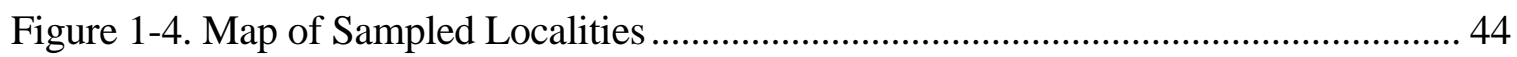

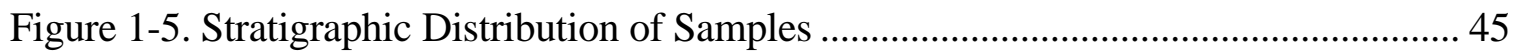

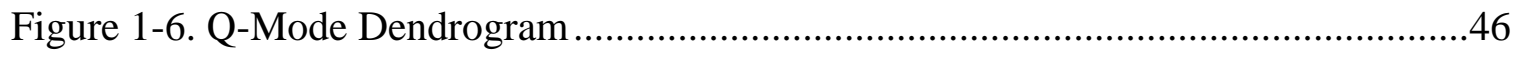

Figure 1-7. Q-Mode Multidimensional Scaling Plot ..................................................47

Figure 1-8. Ames Marine Zone Gradient................................................................48

Figure 1-9. Stratigraphic Distribution of Biofacies ................................................49

Figure 1-10. Q-Mode Dendrogram--No Crinoids.......................................................50

Figure 1-11. Q-Mode Multidimensional Scaling Plot--No Crinoids ..............................51

Figure 1-12. Map and Cross Section Showing Thickness of Selected Ames Marine Zone

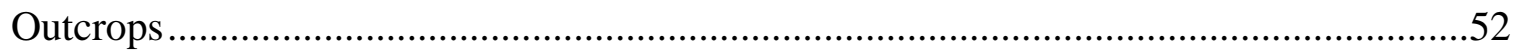

Figure 2-1. Outcrop Belt of the Conemaugh Group ..................................................95

Figure 2-2. Stratigraphic Column of the Conemaugh Group ........................................96

Figure 2-3. Late Pennsylvanian Paleogeography....................................................97

Figure 2-4. Map of Sampled Localities ...............................................................98

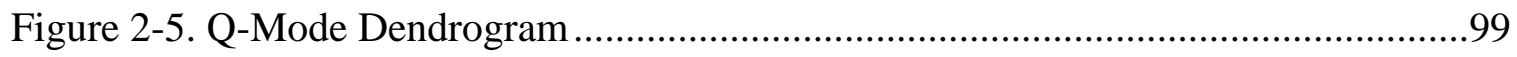

Figure 2-6. Minimum Spanning Tree .................................................................. 100

Figure 2-7. Glenshaw Formation Gradient ............................................................101

Figure 2-8. Relative Extent of Marine Transgression..............................................102

Figure 2-9. Glenshaw Formation Gradient--Extent of Marine Transgression.................103 
Figure 2-10. Glenshaw Formation Gradient--Sampling Region....................................104

Figure 2-11. Line Graph of Randomized Ames Marine Zone Samples ..........................105

Figure 3-1. Stratigraphic Column of the Conemaugh Group ......................................142

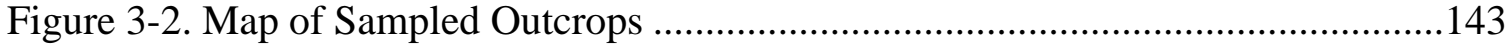

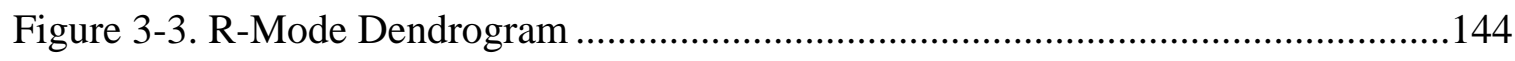

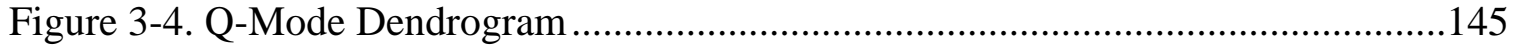

Figure 3-5. Q-Mode Multidimensional Scaling Plot ...............................................146

Figure 3-6. Two-Way Abundance Diagram .........................................................147

Figure 3-7. Canonical Variate Analysis Plots .............................................................148

Figure 3-8. Composite Biofacies Sequences ............................................................149 
1.0.0.0. Gradient analysis of faunal distributions associated with rapid transgression and low accommodation space in a Late Pennsylvanian marine embayment: Biofacies of the Ames Member (Glenshaw Formation, Conemaugh Group) in the northern Appalachian Basin, U.S.A.

Joseph G. Lebold and Thomas W. Kammer

\subsubsection{ABSTRACT}

The Ames Sea, situated in a shallow marine embayment in the Appalachian Basin, was the result of the most extensive marine transgression of the Pennsylvanian in this region. Gradient analysis of the proportional abundance of taxa reveals an environmental continuum across the Ames embayment along which four biofacies were distributed. Biofacies distribution is interpreted to be controlled by salinity, turbidity, and oxygen gradients associated with the geometry of the Ames depositional basin and relative sea-level change.

The eastern portion of the Ames Sea resembled a foredeep trough located on the detrital slope of the recently uplifted Appalachian Highlands. Biofacies 1 and 2 occur exclusively in the eastern part of the Ames depositional basin and are dominated by eurytopic molluscs tolerant of terrigenous influx. Biofacies 3 occurs in both the eastern and western portions of the Ames depositional basin. This biofacies is dominated by the opportunistic brachiopod Neochonetes, which would quickly colonize the seafloor in the wake of transgression. Biofacies 4 occurs exclusively in the western part of the Ames depositional basin and is composed primarily of stenotopic crinoids, bryozoans, brachiopods, and epifaunal bivalves that inhabited a clear water, cratonic ramp on the eastern flank of the Cincinnati Arch.

Vertical variations of faunal assemblages in the Ames Member were the result of variations in relative sea level associated with glacio-eustatic cycles. Biofacies 3, dominated by Neochonetes, was deposited at the base of the Ames Member during the initial rapid transgression in a mostly dysoxic environment with low turbidity and marine salinity. During the first regression, low-density surface water from eastern sources restricted vertical circulation, established a stratified water column, and promoted estuarine conditions in the Ames Embayment. Well-oxygenated surface waters were unable to circulate to the benthic habitat, which led to periodically dysoxic conditions and the establishment of Biofacies 1 and 2, composed of diminutive eurytopic molluscs. A second, stratigraphically-higher occurrence of Biofacies 3 is interpreted to represent a second transgression. However, unlike the first transgression, lithologic and faunal data suggest that the benthic habitat was well-oxygenated. Above the mid-Ames marine zone occurrence of Biofacies 3, Biofacies 1 and 2 were deposited in the final regressive phase as local terrigenous source areas brought increasing turbidity and fluctuating salinity to the Ames Embayment.

Previous paleoecological research on the Ames Member cited freshwater and/or clastic influx as the major controls on biotic distribution, but the results of the present study suggest that oxygen availability was also a major control. Stratification of the water column during the Ames sea-level cycle promoted estuarine circulation that prevented well-oxygenated surface waters from reaching the benthic habitat. This led to the deposition of dark gray to black fissile shales that contain fossil assemblages dominated by diminutive molluscs and brachiopods that were tolerant of low-oxygen conditions. 


\subsubsection{INTRODUCTION}

Eight thin marine zones are distributed among nonmarine units within the Upper Pennsylvanian Glenshaw Formation in the northern Appalachian Basin (Busch, 1984; Busch and Rollins, 1984; Busch and West, 1987). These marine zones record the distal portions of marine incursions of the Midcontinent Sea onto the high shelf formed by the detrital slope of the Appalachian highlands (Heckel, 1995). The thickest and most extensive of these marine units is the Ames Member, which contains a suite of variable fossil assemblages. The Ames Member was deposited during the most extensive marine event of the Pennsylvanian, and the last major marine event of the Paleozoic in eastern North America. Transgression of the Ames Sea from the southwest resulted in the periodic establishment of a variety of marine facies that have been the subject of several modern paleoecological studies (Donahue and Rollins, 1974; Rollins and Donahue, 1975; Nuhfer, 1979; Al-Qayim, 1983; Brezinski, 1983; Saltsmann, 1986, Merrill, 1993). Although these studies have identified biofacies and faunal gradients thought to reflect changing conditions associated with variations in sea level, the role of environmental parameters such as dissolved oxygen, salinity, and turbidity in controlling faunal distribution is not apparent from these studies.

The present study quantitatively measures lateral and vertical faunal variations in the Ames Member in seven outcrops along a general northwest-southeast transect across the northern Appalachian basin. This transect is roughly perpendicular to the depositional axis of the basin, crossing this ancient sea. This provides an opportunity to examine faunal and stratigraphic patterns during the deposition of the most extensive marine event in the Upper Pennsylvanian of this region. Faunal data were analyzed based on how individual taxa may have utilized available resources (e.g., food and habitat) under any given set of environmental 
conditions (Dodd and Stanton, 1990). The observed faunal patterns were combined with sedimentological data to interpret paleoenvironmental conditions present in the Ames Sea.

\subsubsection{STRATIGRAPHY AND GEOLOGIC HISTORY}

The Pennsylvanian System is composed of a single second-order transgressive-regressive unit that begins at the base of the Pennsylvanian and extends to the base of the Permian (Vail et al., 1977). Weller (1930) subdivided Pennsylvanian units in the northern Midcontinent and northern Appalachian Basin into separate packages of lithofacies (Busch \& Rollins, 1984). Each package was considered a formation in the Pennsylvanian System, with the specific lithofacies that comprise them classified as members. The cyclically arranged members of these Pennsylvanian formations were thought to represent shifting depositional environments relative to the shoreline during a single transgressive-regressive cycle. Wanless and Weller (1932) used the term cyclothem to describe these formations in Pennsylvanian strata of North America.

The Conemaugh Group includes rocks deposited during the late Middle to Upper Pennsylvanian (Edmunds et al., 1999). Outcrops are located in southeastern Ohio, southwestern Pennsylvania, western Maryland, West Virginia, and eastern Kentucky in an elliptical belt (Figure 1-1) with the long axis oriented northeast-southwest. The Conemaugh is divided into two formations (Figure 1-2): the Glenshaw Formation, which is distinguished by the presence of many thin marine zones distributed among nonmarine rocks, and the overlying Casselman Formation, which contains two geographically-limited marine zones, the Gaysport and the Skelly (Flint, 1965; Busch, 1984). The boundary between the two formations is located at the top of the uppermost marine zone in the Glenshaw Formation, the Ames Member, which is composed of shale and limestone. 
A review of previous studies of the Ames Member suggests that the lithologic composition of this marine zone is highly variable (e.g., Donahue and Rollins, 1974; Rollins and Donahue, 1975; Nuhfer, 1979; Al-Qayim, 1983; Brezinski, 1983; Saltsmann, 1986, Merrill, 1993). Interpretations of the sea-level history of the Ames Member are equally variable. Studies by Donahue and Rollins (1974), Brezinski (1983), Saltsmann (1986), and Merrill (1993) attributed the lithofacies and biofacies patterns in the Ames Member to a single transgressiveregressive cycle. Al-Qayim (1983) recognized two transgressive-regressive cycles within the Ames Member and Nuhfer (1979) identified three separate transgressive-regressive cycles. Additionally, Nuhfer (1979) divided the Ames Member near Morgantown, West Virginia into: a lower, middle, and upper unit. However, these informal units are not laterally consistent and are of little stratigraphic utility beyond the outcrops included in that study.

The Ames Member is lowermost Virgilian in age, based on fusulinids of the $T$. cullomanensis subzone (Wilde, 1975) and conodonts of the S. elegantulus/S. elongatus zone (Lane et al., 1971). Based on distinctive conodont faunas, the Ames marine zone correlates with the Shumway marine zone in the Illinois Basin and the Oread (Heebner) marine zone in the Midcontinent Basin (Heckel et al., 1998). Paleogeographic reconstruction (Figure 1-3) indicates that during the Middle to Late Pennsylvanian, the Appalachian basin was positioned in the tropics and associated with the accreting "Protopangea" (Heckel, 1995). The basin was located longitudinally near the center of the landmass isolated from the larger Panthalassa and Tethys open tropical sea by about $4000 \mathrm{~km}$ (Heckel, 1995). It was located at the very eastern extent of the shallow, intermittent Midcontinent Sea, which also contained the small, deep and permanently marine Anadarko and Midland basins. During deposition of the Middle to Upper Pennsylvanian units in the Appalachian basin, the major seaway that opened onto the 
midcontinent was located (modern orientations) to the southwest, with the depositional axis oriented northeastward (Brezinski, 1983). The basin was bounded to the northwest by the Cincinnati Arch and to the southeast by the recently uplifted Appalachian highlands (Lamborn, 1951).

The alternating accretion and ablation of glaciers on Gondwana was initially cited as a mechanism for the deposition of Pennsylvanian cyclothems by Wanless and Shepard (1936). Extensive research during the last two decades has established glacial-eustatic sea level changes as the primary control over Pennsylvanian marine cyclothems in the Midcontinent region of the United States (Heckel, 1986; 1995). Evidence for the glacial-eustatic model has received independent support by Crowell (1999), who concluded that glacial episodes on Gondwana persisted from the late Mississippian to the early Permian, and by Veevers and Powell (1987), who showed that the greatest inferred ice volume on Gondwana was attained during Late Pennsylvanian time when cyclothems were best developed in the Midcontinent region.

Late Middle to Late Pennsylvanian glacial-eustatic changes in sea level were controlled by climate change induced by orbital cyclicity (Heckel, 1986). The Glenshaw Formation was deposited in an 8 m.y. interval between $302 \pm 4$ Ma and $294 \pm 6$ Ma (Heckel, 2002). The average duration for the major to intermediate cycles of Heckel (1986) is about 400 k.y. (Heckel, 2002), which corresponds to the 400 k.y. Milankovitch secondary eccentricity, or stretch, cycle (Imbrie, 1985). Thus, the Ames Member, as part of a major cycle, was deposited in less than 400 k.y. The faunal variation within the Ames Member is the result of environmental control rather than evolutionary processes, which generally are on the order of millions of years (Dodd and Stanton, 1990). 


\subsubsection{METHODS}

\subsubsection{Outcrops and Samples}

Seven outcrops distributed from northwest to southeast across the northern Appalachian basin were sampled in detail for paleoecological analysis (Figure 1-4). Sampling localities were selected on the basis of geographic position within the northern Appalachian Basin, accessibility to the outcrop, fossil abundance, and stratigraphic completeness of the Ames Member (lack of erosion by the overlying Grafton Sandstone Member). The purpose of densely sampling only a few outcrops of the Ames Member along a transect in the Appalachian Basin was to focus on small-scale sedimentologic and paleoecologic variations that could then be related to specific environmental factors. Specific locality information is listed in Table 1-1.

Because the focus of this study centers around the faunal variations during deposition of the Ames Member, the lower sampling boundary was placed at the first occurrence of marine body fossils, which usually coincided with the top of the Harlem Coal, where present. The upper sampling boundary was placed at the last occurrence of marine body fossils. Once the upper and lower sampling boundaries were delineated, the Ames was measured and described. A total of 35 samples were taken using 3.7 liter capacity plastic bags from the seven outcrops in this study. Samples were taken at each obvious change in lithology or wherever a distinct faunal change occurred (Figure 1-5). Small bulk samples were taken laterally across the exposures within the same layer where possible. Replicate sampling can be used to offset the patchy distribution of animals observed in most living marine communities (Bennington, 1995, 1996). These small bulk samples were combined in the lab prior to processing. Whole limestone blocks were taken from the outcrops with stratigraphic orientation recorded on the rock. Most of the fossil-bearing units sampled for quantitative analysis represent low energy, mud-dominated (either carbonate or 
clastic) environments where no significant between-facies transport of shelly material would have occurred (Kidwell and Bosence, 1991). However, limestones from the BELL, and CONC outcrops southeastern Ohio contained size-sorted fossil grains and cross bedding indicating some transport of shelly material. For most benthic marine invertebrates, between-habitat transport of shelly material is rare in most settings, and exotic bioclasts comprise only a minor component of most fossil assemblages (Kidwell and Flessa, 1995).

In the laboratory, the shale samples were washed, dried, and sieved. The use of surfactants to disaggregate the shales was abandoned early, due to breakage of thin shells and poor preservation of many of the fossils. With the aid of a binocular microscope, the shale samples were physically disaggregated and fossils were removed using a pin-vice and small dental picks. Limestone blocks were washed and fossils on the outer surface were counted and recorded. The blocks were then carefully broken into smaller pieces and all observed taxa were tallied.

\subsubsection{Guild composition}

In order to analyze the distribution of fossil assemblages, taxa were placed into guilds based on the habitats and trophic modes of fossil organisms. Combining fossil organisms into groups based on their autecological similarities is the basis of the guild concept (Bambach,

1983). Bambach (1983) extended the modern ecological application of the guild concept, which focuses on interspecific competition for resources, and constructed groups based on taxonomic position and autecology. Combining taxa into groups reduces the number of variables per sample and improves the signal to noise ratio of ecologic patterns by increasing the relative magnitude of each grouped variable (Kammer and Lake, 2001). This reduces the dimensionality 
of the data set so that patterns within the data are more easily recognized (Gauch, 1982). It should also be mentioned that grouping variables can obscure finer patterns in the data set, but the groups constructed in this analysis are an attempt to find a middle-ground between overly generalized and overly specific variable combinations.

To define the guilds, taxa were identified and placed into class-level groupings with the exception of the Phylum Bryozoa. Branching bryozoans (BRYO) were not subdivided into classes because their feeding methods are thought to be more or less similar for all Paleozoic classes (Boardman and Cheetham, 1987). Semi-infaunal deposit-feeding scaphopods (SCAPHO), nektonic predatory or scavenging cephalopods (CEPHALO), and stalked suspension-feeding crinoids (CRINOID) were put into separate guilds because the members within each of those classes have similar autecology as compared to members outside of their class. Gastropod, bivalve and brachiopod taxa were further subdivided based on autecological differences between members within the same class, as discussed below (Table 1-2). Identifications of major fossil groups within the Ames were based on available taxonomic studies and include: Anderson (1986) and Hoare et al. (1997) for gastropods; Hoare et al. (1979) for bivalves; and Sturgeon and Hoare (1968) for brachiopods. Other fossil groups were identified using Lintz (1958), Hoare and Miller (1996a, b), Schwimmer and Sandy (1996), and the Treatise on Invertebrate Paleontology, (e.g., Cox, 1960).

Paleoecological aspects of Paleozoic gastropods are not well understood (Aigen, 1974; Harper and Rollins, 1985; Anderson, 1986). In the present study gastropod guilds were based on shell morphology, with the exception of the bellerophontid gastropods, where interpretations of the mode of life of these planispiral gastropods do exist (e.g., Harper and Rollins, 1985). However, the taxonomic affinity of bellerophontid gastropods has been the subject of recent 
debate as some researchers consider bellerophontids to have been molluscs of uncertain affinity and not gastropods (e.g., Cherns et al., 2004). In either case, similar habitat preferences and life strategies between the bellerophontids and other Paleozoic gastropods permit their assignment to the gastropod guild in the present study in light of their taxonomic affinity. High-spired gastropods including Donaldina, Pseudozygopleura, Meekospira, Girtyspira, and Strobeus were grouped as the loxonemitid (LOXONEM) guild, which are thought to be mostly epifaunal deposit feeders, herbivores (Aigen, 1974, Aberhan, 1994) and some carnivores (Aberhan, 1994). Low-spired gastropods including Glabrocingulum, Trepospira, and Shansiella, which are thought to be epifaunal deposit feeding or herbivorous archaeogastropods (Aigen, 1974), were grouped in the pleurotomarid (PLEURO) guild. Planispiral gastropods were divided into the Euphemites (EUPHEM) guild, which is thought to be infaunal to semi-infaunal deposit feeding burrower or plower (Harper and Rollins, 1985), and the Bellerophontids (BELLERO) Bellerophon (Bellerophon), Knightites (Cymatospira), Knightites (Retispira), and Pharkidonotus which are thought to be active epifaunal deposit feeders and herbivores (Harper and Rollins, 1985).

Infaunal bivalves were divided into infaunal deposit feeders (INDEPBIV) and infaunal suspension-feeders (INSUSBIV). The INDEPBIV guild includes the nuculid bivalves Nuculopsis, Palaeoneilo, Paleyoldia, and Phestia that were presumably rapid, free-burrowing shallow deposit-feeders (Stanley, 1970). The INSUSBIV guild includes the mytilid Promytilus, the trigonoid Schizodus, veneroids Permophorus and Astartella, the pholadomyoid Edmondia, and Anthraconia (Stanley, 1970). The suspension-feeding bivalve group is thought to be a mixture of infaunal to semi-infaunal endobyssate and free-burrowing suspension feeders (Stanley, 1970, 1972). The last bivalve guild is composed of suspension-feeding epifaunal 
bivalves (EPIBIV) represented by the pectinids Dunbarella, Aviculopecten, Acanthopecten, and Paleolima.

Brachiopods were divided into groups based on shell morphology and habitat preference. The chonetid guild (CHONET) is composed of the relatively flat, thin-shelled, free-lying Neochonetes. Productid brachiopods (PRODUCT) were grouped together and include the inflated, free-lying Juresania, Linoproductus, and Cancrinella that possess spines thought to provide buoyancy on soft muddy substrates (Grant, 1966). However, there has been speculation that the spines were also used for anchorage in high energy environments or as protection from predators (Leighton, 2000). Pedunculate brachiopods (PEDUNC) include the biconvex to planoconvex, pedically-attached Composita and Neospirifer. During the analysis, the pedunculate brachiopod Crurithyris was removed from the PEDUNC guild and placed in its own guild (CRURI) after it became apparent that Crurithyris had a very different distribution from all other brachiopods. Strophomenid brachiopods (STROPHO) were represented by the relatively flat, free-lying suspension feeder Derbyia.

\subsubsection{Data}

Abundance data of taxa are the sum of identifiable invertebrate fossils within 23 Ames samples. Many of the original 35 samples taken from the seven outcrops in this study were combined if they were stratigraphically adjacent and contained similar taxa or omitted if they were barren. A preferred minimum of 300 fossils was collected from each sample in order to determine the relative abundance of individual taxa (Dennison and Hay, 1967). At this sample size there is only a $5 \%$ probability that species with a $1 \%$ abundance will be missed, assuming no systematic bias by the observer. Species with a $3 \%$ abundance have a probability of only $0.01 \%$ 
of being missed. Isolated fragments of crinoids and colonial bryozoans were included in the fossil counts, as they represent a significant proportion of the faunal content and are important environmental indicators.

Brachiopod and mollusc fossil counts were derived using the MNI (minimum number of individuals) method for fragmentary remains (Gilinski and Bennington, 1994). Because each portion of the bulk sample was exhaustively processed for fossilized remains, counting each valve as an individual would not be appropriate (Gilinski and Bennington, 1994). Isolated bryozoan and echinoderm fragments were counted using the XNI (maximum number of individuals) method because their remains were not taxonomically distinctive, and thus, could not be confidently assigned to a specific taxon(a). The use of these methods results in either an underestimation of the number of individuals (MNI), or overestimation of the number of individuals (XNI). It is understood that using both methods in the same study will result in an overestimation of the number of bryozoan and crinoid individuals when compared to brachiopods and molluscs. However, the contribution of bryozoans and crinoids to the overall biovolume is significant. Their remains present important paleoecologic information regarding conditions during deposition. Tests to determine the effect of overestimating their abundance are presented later in the methods section (see Multivariate analysis).

Fossil assemblages tallied in the present study represent samples of populations that lived during deposition of the Ames Member. These assemblages are not classified as discrete community types (e.g. Johnson, 1962) because studies in modern ecology indicate that boundaries between community types are not always clearly defined (Whittaker, 1975). More often, community boundaries overlap as species respond to the physical environment and competitive pressure from other species that inhabit similar environments (Holland et al., 2001). 
The latter pattern relies on strong independence between species consistent with the individualistic hypothesis of species distribution proposed by Gleason (1926). In this hypothesis, species are distributed along environmental gradients, each reacting to physical changes independently. Changes in species distributions are a response to different physical conditions along these gradients.

\subsubsection{Multivariate Analysis}

Non-metric multidimensional scaling (MDS) and cluster analysis were used to explore and identify patterns within samples (Q-mode) utilizing the software package NTSYSpc-2.02i (Rohlf, 1998). The similarity index used for the Q-mode analysis was cosine theta (1-COSØ), which is the appropriate similarity coefficient for Q-mode analysis (Joreskog et al., 1976). Other similarity coefficients were applied with similar results. Cluster analysis produces a dendrogram that corresponds to the degree of similarity between objects. Objects with the highest degree of similarity are grouped together. The next most similar objects are then successively connected to these. MDS places objects (variables or samples) in low dimensional, usually two or three, Euclidean space. The distance between objects corresponds to the complement of cosine theta (1-COSØ). Objects in close proximity are the most similar, whereas objects that plot away from each other are less similar. The goodness-of-fit is ranked by the stress index, which measures how well a particular map of similarities corresponds to the observed distance matrix. Stress values range from 0 to 1 ; low values indicate a good fit, whereas high values ( $>0.40)$ indicate a poor fit (Rohlf, 1998).

Multivariate analysis was also used to determine if guilds counted using the XNI counting method were masking the ecological signal of guilds counted using the MNI method. 
Q-mode cluster analysis was performed on the relative abundance of data with and without crinoids. The CRINOID guild was chosen for this test because of the taxa counted using the XNI method, only the crinoids were present in numbers comparable to brachiopod and mollusc guilds. If the crinoids are indeed masking the influence of other guilds, then samples with abundant crinoids would be distributed randomly among the remaining sample groups when crinoids are excluded. If crinoids are not masking the ecological signal of the other guilds, then samples that contained abundant crinoids should cluster together or be grouped with samples dominated by guilds that have similar environmental preferences.

\subsubsection{RESULTS}

A total of 7490 fossils were tallied in the 23 final samples derived from the 35 field samples (Table 1-3). The data were normalized to percent abundance for comparison of guild proportions in the final analysis. Normalizing the data was done to offset the effect of combining stratigraphically adjacent samples with similar assemblages, which resulted in widely uneven total fossil counts between samples (N, Table 1-3).

Preliminary analysis revealed that relative abundance data illustrated clear patterns in the distribution of the 16 guilds (Table 1-3). These patterns were enhanced when guilds were placed into four Bambachian Megaguilds (Droser et al., 1997) based on similar distribution within samples that indicated similar environmental preferences (Table 1-4). Megaguilds (listed with assigned guilds) are: 1. INBIV/CRURI (CRURI, INDEPBIV, and INSUSBIV), which includes the brachiopod Crurithyris, and infaunal deposit- and suspension-feeding bivalves; 2 . GAST/SCA (BELLERO, EUPHEM, LOXONEM, PLEURO, SCAPHO), which includes bellerophontid, loxonemitid, and pleurotomarid gastropods and the scaphopod Plagioglypta; 3. 
BRACHS (CHONET, PEDUNC, PRODUCT, and STROPHO), Neochonetes, pedunculate, productid, and strophomenid brachiopods; and 4. STENO (BRYO, CEPHALO, CRINOID, and EPIBIV), stenohaline bryozoans, cephalopods, crinoids, and epifaunal bivalves. Bryozoans, crinoids, and cephalopods are known stenohaline organisms with few exceptions (Dodd and Stanton, 1990; Kammer and Lake, 2001). Epifaunal bivalves commonly co-occurred with these stenohaline groups and were placed into this megaguild.

Q-mode cluster analysis produced a dendrogram of sample groups that mimics the separation into megaguilds (Figure 1-6). Q-mode MDS was used to identify links between clusters and placed Ames Member samples along a two-dimensional curvilinear gradient with a stress of 0.06, which Rohlf (1998) evaluated as excellent in regards to how well the resultant map of similarities corresponds to the observed distance matrix (Figure 1-7). The samples were then plotted along a horizontal axis based on their respective position along the curvilinear gradient (Figure 1-8). Clastic samples from the eastern (West Virginia) portion of the Ames depositional basin fell on one end of the axis, whereas carbonate samples from the western (Ohio) portion fell on the opposite end of the axis.

In order to analyze the gradient produced by Q-mode MDS, the distributions of megaguilds were plotted along the axis defined by MDS (Figure 1-8). The means and distributions of these megaguilds vary among the samples and each megaguild displays an individualistic response to environmental conditions along the gradient. Each megaguild has a peak abundance along the gradient and declines on either side in an approximate bell-shaped, or Gaussian, distribution. Overlap in the distributions indicates that discrete faunal assemblages are not present and that intergrading faunal assemblages exist along the environmental gradient, making the placement of samples into groups somewhat arbitrary. While this reflects practical 
limitations when placing objects that exist along a continuum into groups, it does not overshadow the usefulness of assigning samples to a particular faunal type (e.g., nearshore fauna and offshore fauna) when describing faunas (Gauch, 1982).

In the present study, groups of samples are distinguished by the dominance of a specific megaguild, which accounts for the greatest percentage of taxa in the sample group (Figure 1-8). Thus, the resultant sample groups each contain a relatively distinct fossil assemblage that can be characterized as a biofacies. Biofacies are labeled 1-4 in the order that they appear along the environmental gradient from clastic- to carbonate-dominated samples (Figure 1-8). Sequential peaks of different megaguilds indicates that the dominant megaguild in each biofacies was successful within a specific set of environmental conditions, but was outcompeted by another megaguild under a different set of environmental conditions along the gradient.

\subsubsection{BIOFACIES DESCRIPTION AND ENVIRONMENTAL INTERPRETATION}

Biofacies 1, 2, and 3, identified in the present study, are dominated by taxa that employ opportunistic life-strategies. Opportunistic taxa, or r-strategists, are species that produce numerous offspring that mature rapidly (Brenchley and Harper, 1998). They tend to be eurytopic species tolerant of stressful or changing conditions and are the first taxa to colonize a new

environment (Malinky and Heckel, 1998). Five of these opportunists; Crurithyris, Neochonetes, Nuculopsis, and the microgastropods Donaldina and Girtyspira are the dominant and often exclusive taxa that compose the CHONET, CRURI, INDEPBIV, and LOXONEM guilds, respectively. These guilds account for nearly $73 \%$ of the total fossils tallied in this study. The distinguishing characteristic of biofacies 1-3 is a change in the dominant opportunist. This pattern of distribution is similar to the pattern of community replacement by reorganization 
(Miller, 1986). In this situation, the abundance of a dominant species expands or contracts in response to changing environmental conditions through time. This usually involves an overwhelmingly dominant or opportunistic organism that can respond to environmental variability or disturbance frequency over sub-evolutionary time (i.e., much less than 1 million yr). This pattern tends to be more prominent in nearshore marine or estuarine settings, such as the shallow Ames Embayment, that are more prone to physical disturbances.

\subsubsection{Biofacies 1}

Biofacies 1 is characterized by the dominance of the INBIV/CRURI megaguild (Table 14). Within this megaguild, the INDEPBIV guild, dominated by the eurytopic bivalve Nuculopsis, is the most abundant and accounts for nearly $53 \%$ of the total fossils in this unit. Two other taxa, Crurithyris and Euphemites, comprise 25\% and 8\% of the fossils respectively, although their distributions are antithetic, indicating that they responded to slightly different environmental conditions within the INBIV/CRURI megaguild (Figure 1-8). Samples assigned to this biofacies are either a fissile, black phosphatic shale in the middle of the Ames Member at the GRR outcrop, samples GRR6A and 6B, or light gray to green shale at the top of the Ames Member in samples FAIR4 and FAIR5 (Figure 1-5).

Biofacies 1 represents a euryhaline faunal assemblage tolerant of variable salinity and turbidity levels associated with nearshore clastic sources (Figure 1-8 and Table 1-5). In Midcontinent faunas, increased clastic influx and reduced salinities caused by runoff from clastic sources commonly favor eurytopic molluscs (Boardman et al., 1984). In addition, Crurithyris has been interpreted as having a greater tolerance to fluctuating conditions associated with terrigenous runoff when compared to other brachiopods (Brezinski, 1983). The occurrence of 
this biofacies in both light-and dark-colored shale samples suggests that taxa in this biofacies were also tolerant of low oxygen levels. Light-colored samples are interpreted as welloxygenated environments where sufficient oxygen was available in the substrate to oxidize organic detritus. The dark gray to black shale samples are interpreted as low oxygen environments. Insufficient oxygen levels permitted the substrate to become enriched in organic detritus that contributed to their dark color (Demaison and Moore, 1980). In addition to the dark color of the shales, most individuals in the INDEPBIV guild are very small $(<2 \mathrm{~mm})$, depositfeeding nuculid bivalves that are a common component of assemblages in oxygen deficient basins (Kammer et al., 1986).

\subsubsection{Biofacies 2}

Biofacies 2 is characterized by the dominance of the GAST/SCA megaguild (Table 1-4). Overall, the gastropod guilds BELLERO, EUPHEM, LOXONEM, and PLEURO account for nearly $69 \%$ of the fossils. Although the SCAPHO guild accounts for less than $1 \%$ of this megaguild, the distribution was very similar to gastropods, and they were grouped together. The INDEPBIV and CHONET guilds are also present and compose $12 \%$ and $13 \%$ of the fossils in this biofacies, respectively.

Very little documentation is available concerning the habitat of Paleozoic gastropods. Previous paleoecological interpretations of other Paleozoic gastropods based on the ecology of extant forms has resulted in the oversimplification of their mode of life (Harper and Rollins, 1985). Many Paleozoic gastropods, similar to the taxa in the present study, are found in dark, fine-grained sediments, which contradicts modern analogs that indicate non-predatory gastropods are strictly herbivores limited to clear water environments with firm substrates (Peel, 1978). 
Their occurrence in dark, fine-grained sediments has led several researchers to conclude that many Paleozoic gastropods were deposit feeders (Aigen, 1974; Rollins et al., 1979).

The position of Biofacies 2 along the environmental gradient suggests that it was deposited in a nearshore environment, but it was not subjected to the same degree of turbidity as Biofacies 1 (Figure 1-8 and Table 1-5). The change in dominance from infaunal deposit-feeding bivalves to semi-infaunal to epifaunal deposit-feeding gastropods indicates a reduction in turbidity and local currents. This reduction would allow previously deposited muds to settle, increasing substrate firmness, and promote the accumulation of organic detritus on the substrate. Epifaunal deposit feeders would benefit from both a firmer substrate for locomotion and the accumulation of organic detritus as a readily available food source. The position of Biofacies 2 along the environmental gradient also suggests that it may include two distinct salinity ranges (Figure 1-8 and Table 1-5). The nearly exclusive occurrence of bivalves and gastropods in samples ANMO4 and BELN2 suggest that salinity was variable. However, a steady increase in the co-occurrence of gastropods and stenohaline brachiopods in samples FAIR1B, ANMO2 and FAIR 2 suggests normal marine salinity.

Although the position of Biofacies 2 on the gradient in Figure 8 indicates a reduction in turbidity compared to Biofacies 1, oxygen availability was still inferred to be quite low (Table 15). Samples FAIR1B, ANMO2, and FAIR2 were taken from dark gray shales near the base of the FAIR and ANMO outcrops (Figure 1-5) and contain a high proportion (62\%) of Microgastropods. Microgastropods are defined arbitrarily as post-larval gastropods that are $1 \mathrm{~cm}$ or less in height (Fraiser and Bottjer, 2004). Post-larval development was determined by the number of whorls present on specimens in the LOXONEM guild. The presence of between eight and ten ornamented whorls on the most complete specimens indicates development beyond 
the protoconch stage that, at its maximum, is generally associated with the first six to eight formed whorls (Jablonski, 1985). Microgastropods are now known to be eurytopic taxa that commonly dominate low-oxygen settings during the Carboniferous period (Fraiser and Bottjer, 2004).

The only other fossil in significant numbers (13\%) in these three samples is the chonetid brachiopod Neochonetes. Malinky and Heckel (1998) recognized that Neochonetes was eurytopic, but were unable to determine the range of environmental conditions Neochonetes could tolerate. The occurrence of Neochonetes, as the only taxon consistently associated with the microgastropod-bearing dark shale samples, suggests that it was slightly eurytopic with respect to oxygen.

\subsubsection{Biofacies 3}

Biofacies 3 is characterized by the dominance of the BRACH megaguild (Table 1-4). However, the chonetid brachiopod Neochonetes comprises the overwhelming majority of fossils recovered from this biofacies, accounting for nearly $72 \%$ of the fauna. Bedding planes completely covered with the shells of Neochonetes are probably the most easily recognized and commonly described fossil accumulations in the Ames Member (e.g., Donahue and Rollins, 1974; Nuhfer, 1979; Al-Qayim, 1983; Brezinski, 1983; Saltsmann, 1986; Merrill, 1993). Biofacies 3 occurs at the base of nearly every outcrop in this study, with the exception of CONC (Figure 1-9). These basal samples are composed of dark gray to black calcareous shales with some specimens of Neochonetes coated with pyrite. Biofacies 3 occurs a second time stratigraphically higher in the sections at the GRR, FAIR, and ANMO outcrops (Figure 1-9). The GRR sample is a light gray shale, the FAIR sample is a gray shaley limestone, and the 
ANMO sample is from a gray fine-grained limestone.

The position of Biofacies 3 along the environmental gradient indicates that it was deposited in a predominantly offshore, normal marine environment with low turbidity (Figure 18 and Table 1-5). However, the occurrence of Biofacies 3 in both dark shales and light-colored shales and limestones suggests that this biofacies was capable of surviving in a range of environmental conditions. Samples ANMO3, BELL2, FAIR3, GRR9A and 9B, and NEW1 that contain Biofacies 3 are light-colored shale and limestone samples taken either from the middle of the Ames marine zone in north-central West Virginia, or the base of the Ames marine zone in Ohio. These samples are positioned near the offshore end of the environmental gradient and overlap with the stenotopic Biofacies 4 (see Biofacies 4 description below; Figure 1-8). This suggests that these samples were deposited under mostly oxic conditions with low clastic influx and normal marine salinity in an offshore environment. Neochonetes has commonly been associated with offshore environments within Pennsylvanian cyclothems (e.g., Nuhfer, 1979; Brezinski, 1983; Boardman et al.,1984; Malinky and Heckel, 1998). This interpretation is also consistent with the findings of Olszewski and Patzkowski (2001) who concluded that Neochonetes most commonly inhabited well-oxygenated environments.

The dark shale samples ANMO1, BELN1, FAIR1A, GRR5A and 5B of Biofacies 3 are all found at the base of the Ames marine zone and overlap with samples of Biofacies 2 that were deposited under low-oxygen conditions (Figure 1-8). The laminated appearance and dark color of the shale samples suggests that there was insufficient oxygen in the sediment to support bioturbating organisms or contribute to the oxidation of organic material. This situation is analogous to the exaerobic biofacies of Savrda and Bottjer (1991) where in situ shelly body fossils are contained within dark, organic-rich sediments. In addition, the overwhelming 
dominance of many Biofacies 3 samples by a single, thin-shelled, chonetid brachiopod is consistent with low-diversity faunas associated with the exaerobic biofacies (Savrda and Bottjer, 1991). The association of Neochonetes with both Biofacies 2 and Biofacies 4 further supports the interpretation that it was eurytopic with respect to oxygen.

One sample, GRR9B, within the BRACH megaguild is not dominated by Neochonetes, instead it is dominated by the pedunculate brachiopod Composita, which accounts for nearly 99\% of the fossils recovered from this sample. These brachiopods are found in several densely packed shell pavements that compose thin, reddish-brown limestone beds separated by thin layers of silty, calcareous green shale at the top of the GRR fossil zone (Figures 1-5 and 1-9). Paleoecological studies in the Carboniferous concluded that Composita inhabited welloxygenated environments (Olszewski and Patzkowski, 2001). Although stenotopic crinoids and bryozoans were found during surface collecting, the bulk samples produced only rare bryozoans. The silty shales that separate the limestone beds most likely represent periodic clastic influx that disrupted carbonate production. Crinoids and bryozoans may have been limited by periodic turbidity, whereas articulate brachiopods have the ability to remove excess sediment from their feeding structures (Thayer, 1986). Its position along the gradient (Figure 1-8) suggests that this sample thrived in an offshore environment as did the other light-colored shale and limestone samples assigned to the BRACH megaguild.

\subsubsection{Biofacies 4}

This biofacies is characterized by the STENO megaguild, which accounts for nearly $65 \%$ of the fossils recovered from the samples (Table 1-4). Within the STENO megaguild, CRINOID fragments account for nearly 59\% of the fossils, articulate brachiopods account for $34 \%$, and 
both bryozoans and epifaunal bivalves occur in their greatest proportion, $5 \%$ and $0.86 \%$ respectively, in this biofacies. Biofacies 4 occurs exclusively in the limestone samples BELL3, BELL5, and CONC from the two westernmost localities in Ohio (Figures 1-5 and 1-9).

The abundance of crinoids, articulate brachiopods, and bryozoans indicates that these sediments were deposited under normal marine salinity and minimal turbidity (Table 1-5). These taxa are stenohaline organisms with few exceptions and are suspension feeders that require low turbidity in the water column to obtain food (Aller and Dodge, 1974). Neospirifer has been shown to be quite intolerant of turbidity and/or variations in salinity in Pennsylvanian epicontinental seas (Stevens, 1971; Brezinski, 1983). All Ames crinoids are pinnulate cladids (see J.J. Burke in the bibliography section of Webster, 2003), the dominant crinoids of the Late Pennsylvanian (Holterhoff, 1996). The abundant crinoids and brachiopods in Biofacies 4 make this assemblage most similar to the moderate-depth stenotopic communities recognized by Boardman et al. (1984) that were deposited in well-oxygenated environments with normal marine salinity.

The results of multivariate analyses indicate that mixing MNI and XNI counting procedure did not effect the position of samples with a high abundance of the CRINOID guild along the gradient. All three western (Ohio) samples assigned to Biofacies 4 clustered with the adjacent Biofacies 3 (Figure 1-10). CONC and BELL3 were grouped with Biofacies 3 at a high degree of similarity due to a significant (21.11\%) abundance of taxa in the BRACH guild group. BELL5 clustered at low similarity with Biofacies 3 due to a high occurrence of Crurithyris. In addition, the three samples maintained a similar position at the carbonate-dominated end of the gradient recognized on the MDS plot (Figure 1-11). These results indicate that the mixing of MNI and XNI methods did not mask any underlying ecological signal of the other taxa in the 
Biofacies 4 samples.

\subsubsection{BIOFACIES VARIATIONS}

\subsubsection{Lateral Variation}

The general outcrop appearance of the Ames Member differs laterally from western exposures in southeastern Ohio to eastern exposures in north-central West Virginia (Figure 112A). In the western portion of the Appalachian Basin (Ohio and westernmost Pennsylvania), the average thickness of 98 measured sections of the Ames Member is $0.9 \mathrm{~m}$ with only five reported Ames Member outcrops measuring greater than $3 \mathrm{~m}$ (data from Busch, 1984 and the present study). In contrast, in the eastern portion of the basin (southwestern Pennsylvania and north-central West Virginia) the average thickness of 14 measured sections of the Ames Member is $5.2 \mathrm{~m}$, with only four occurrences measuring less than $3 \mathrm{~m}$ (Figure 1-12A; data from Busch, 1984 and the present study). The lithology of the Ames Member changes laterally from clasticdominated in the eastern part of the basin to carbonate-dominated in the western portion of the basin (Figure 1-5). Studies by Al-Qayim (1983) and Merrill (1988) also reported that the thickness and shale content of Ames Member increased to the east.

The southeastern (southernmost Pennsylvania and West Virginia) portion of the basin can be characterized as a foredeep trough (Figure 1-12B), the result of increased subsidence with proximity to the recently uplifted Appalachian highlands (Joeckel, 1995). Several studies including Arkle (1974), Al-Qayim (1983), Merrill (1988), and Joeckel (1995) have shown that net subsidence rates during Conemaugh times were higher in this part of the basin. Faster subsidence would provide more accommodation space for sediments accumulating in the eastern portion of the basin, resulting in an increase of the preserved thickness of the Ames Member. 
Slower subsidence in the northwestern (Ohio) portion of the basin would have provided less accommodation space for sediments and a lower preserved thickness of the Ames Member. Away from the influence of eastern clastic sources, deposition took place on a stable cratonic ramp leading to carbonate-dominated intervals. On the southeastern (north-central West Virginia) portion of the basin, proximity to eastern sediment sources from the uplifted Appalachian highlands would have limited carbonate production and promoted the deposition of clastic-dominated intervals.

The different sedimentary histories of the eastern and western margins also had an effect on biofacies distribution. Biofacies 1 and 2 occur exclusively in the eastern part of the Ames depositional basin (Figure 1-9). These biofacies are comprised of a combination of suspensionand deposit-feeding eurytopic molluscs and opportunistic brachiopods tolerant of increased turbidity, variable salinity, and periodically dysoxic conditions associated with eastern clastic sources. In contrast, Biofacies 4 occurs exclusively in the western part of the Ames depositional basin. It is composed primarily of stenotopic, suspension-feeding crinoids, bryozoans, and brachiopods that inhabited a relatively shallow, clear-water shelf.

Lateral variations in the Appalachian Basin are similar to lateral variations reported from the Midcontinent Basin by Malinky and Heckel (1998). In the southern (Oklahoma) portion of the Midcontinent Basin, higher sediment influx from Ouachita source areas inhibited carbonate deposition in much the same way as did Appalachian source areas in the eastern portion of the Ames Embayment. Marine deposits near source areas in the Ames Embayment and Midcontinent Basin are clastic-dominated and contain faunas composed of molluscs, due to the greater tolerance of molluscs to clastic influx. In the northern (Iowa and Nebraska) portion of the Midcontinent Basin, water depth was shallower, and well-oxygenated waters were 
available to support normal marine crinoid-brachiopod assemblages similar to those in the western (Ohio) portion of the Ames Embayment.

\subsubsection{Vertical Variation}

1.6.2.1. Transgression 1...Exposures of the Ames Member also exhibit significant vertical variations in lithology and composition of benthic faunas related to sea level change. The initial Ames transgression is marked by the stratigraphic juxtaposition of the non-marine Harlem Coal and the overlying Biofacies 3 at the base of the Ames marine zone. The contact between the two units is sharp, and the overlying Ames usually does not contain any rip-up clasts derived from the underlying coals. Typically, wave action associated with shallow-water conditions accompanied the advancing shoreline during transgression and produced a ravinement surface overlain by a transgressive lag deposit (Van Wagoner et al., 1990). The lack of a ravinement surface at most localities of the Ames marine zone may be due to the resistance of peat deposits to erosion (Joeckel, 1995; Bennington, 1996). An equally plausible explanation for the lack of a ravinement surface may also account for the lack of coarse-grained sediments and nearshore faunas above the Harlem Coal. Transgression of the Ames Sea progressed across a low relief coastal plain (Joeckel, 1995) at a very rapid rate (Merrill 1973; Donahue and Rollins 1974; Brezinski, 1983; Heckel, 1994). The flooded coastal plain would only have been exposed to wave action for a relatively short period of time before offshore conditions were established.

The initial Ames transgression led to the establishment of Biofacies 3, dominated by Neochonetes, which consistently occurs at the base of the Ames marine zone as well as other Pennsylvanian marine zones. This has led many researchers to conclude that chonetid brachiopods were opportunistic taxa that rapidly colonized the seafloor during transgression 
(Jacobs, 1976; Rollins et al., 1979; Brezinski, 1983; Saltsmann, 1986; Merrill, 1993; Bennington, 1996; Malinky and Heckel, 1998). In north-central West Virginia, samples ANMO1, BELN1, FAIR1A, and GRR5A that contain Biofacies 3 were all taken from dark gray to black shales. Fossils are concentrated at the base of the black shale units with preservation ranging from good (intact, whole specimens) to poor (intact molds). The variation in preservation styles indicates that while some well-preserved individuals may have been rapidly buried by sporadic episodes of sedimentation, many specimens were exposed on the seafloor due to slow rates of sedimentation, during which shell material deteriorated (Brett and Baird, 1986). These features, combined with the juxtaposition of coals and the offshore Biofacies 3, suggest that transgression of the Ames Sea was rapid. Wignall (1991) determined that during rapid transgression, black shales can be deposited directly above shallow-water deposits. A rapid rise in relative sea level can lead to starved-basin conditions as sediments become trapped in nearshore estuaries. Offshore conditions are rapidly established over thin shallow water deposits (in this case, nonmarine coals) leading to density stratification of the water column and oxygen-depleted bottom waters.

In Ohio, transgression of the Ames Sea led to the establishment of clear water, normal marine conditions and the establishment of Biofacies 4 in the CONC, BELL3, and BELL5 samples (Figure 1-9). The CONC and BELL intervals were deposited in relatively shallow water under the influence of local currents as indicated by cross-bedding and some evidence of sizesorting. The nearly exclusive occurrence of suspension-feeders that require some influence of local currents to bring food to their feeding structures also suggests local current influence (Jorgenson, 1966). Shallow water conditions persisted throughout the remainder of the Ames Sea in Ohio. The disappearance of marine fossils at the top of the Ames Member coincides with 
a change in lithology from limestone to a brown to buff platy shale with rare plant fragments at the CONC and BELL outcrops and a gray micaceous silty shale at the NEW outcrop. The upper surface of the limestone in the Ames Member is irregular at the BELL and CONC outcrops and shows up to several centimeters of relief. In addition, the upper $5 \mathrm{~cm}$ of the CONC outcrop has a reddish-mottled texture. These features are commonly found on the upper surface of "upper" limestones within the regressive portion of Midcontinent cyclothems. The "upper" limestones were exposed to oxygen-rich meteoric water during diagenesis, which oxidized the organic matter, leached unstable grains and deposited sparry calcite in void spaces (Heckel, 1984). This process apparently took place in the subsurface through a series of progressively more nonmarine diagenetic environments.

1.6.2.2. Regression 1...In north-central West Virginia, the change from transgression to regression is signaled by an upward change from light and dark gray shales dominated by Neochonetes at the base of the Ames Member to dark gray, platy to black, fissile shales dominated by molluscs. During regression, a drop in relative sea-level is often accompanied by an increase in terrigenous runoff. The increased outflow of less dense fresh water into the Ames Embayment set up estuarine circulation, which led to a stratified water column and prevented the circulation of well-oxygenated surface waters to the benthic habitat. Low-oxygen conditions at or near the sediment water interface were established under a density-driven halocline in relatively shallow water (Heckel, 1991). The substrate became enriched in organic detritus, which led to the deposition of dark shales (Demaison and Moore, 1980). The mollusc-dominated fauna (Biofacies 1 and 2) present in the dark shales have a small $(<2 \mathrm{~mm})$ body size and are predominately deposit feeders. These features are typical of fossil assemblages that inhabited 
oxygen-deficient environments (Kammer et al., 1986).

The mollusc-dominated shales vary laterally from a fissile, black, phosphatic shale that contains Biofacies 1 at the GRR outcrop in Morgantown, to a dark gray platy shale that contains Biofacies 2 at the FAIR and ANMO outcrops that are $25 \mathrm{~km}$ and $60 \mathrm{~km}$, respectively, to the southwest. This variation in the mollusc-dominated shales may be due to freshwater input from a local terrigenous source area that became increasingly active and eventually delivered sediments to the Morgantown area during early regression. The GRR6 interval (Figures 1-5 and 1-9) contains phosphate nodules that may have formed in low-oxygen sediments, similar to deposits off the modern coast of Peru (Kidder, 1985). The formation of phosphates in low oxygen environments has been used to explain phosphates in Midcontinent black shales. To account for the widespread $\left(>160,000 \mathrm{~km}^{2}\right.$ ) distribution of phosphate in the Midcontinent, Heckel (1977) attributed the low oxygen conditions to increased primary productivity in surface waters caused by regional upwelling of nutrient-enriched deep water. However, the occurrence of phosphate in the Ames Member is very limited, based on its restriction to a single exposure in the Morgantown area. An alternative explanation to account for the limited occurrence of phosphate is that prior to significant sediment influx from local source areas during regression, freshwater influx could have led to the development of a stable halocline in the Morgantown area promoting reduced-oxygen conditions within the substrate. Nutrient-rich freshwater from these sources could have delivered phosphates that would become enriched in the reduced-oxygen sediments. Modern phosphates are often located in areas with excessively slow sedimentation rates, with phosphates sometimes accumulating under estuarine conditions (Boardman et al., 1984). The arrival of clastic sediments from local source areas near Morgantown occurs just after the deposition of the phosphatic dark shales in samples GRR6A and 6B. The input of 
sediments and/or sea level fall that accompanies regression caused a breakdown of the stratified water column and the end of black shale deposition (Wignall, 1991). Directly above the dark shales is an unfossiliferous, light-colored shale (samples GRR7A and 7B; Figure 1-5) containing abundant siderite nodules or nodular layers that mark the onset of prodelta sedimentation (Maples, 1986).

1.6.2.3. Transgression 2 ...A second transgression in the middle of the Ames marine zone is signaled by the return of Biofacies 3 at the ANMO, FAIR and GRR outcrops (Figure 1-9). Both the FAIR3 and ANMO3 samples were taken from limestone units and contain abundant Neochonetes, as well as large (up to $5 \mathrm{~cm}$ ) productid brachiopods and the infaunal bivalve, Edmondia. These are some of the largest benthic fossils collected in the eastern, clasticdominated portion of the Ames Basin and suggest well-oxygenated, marine conditions. At the GRR outcrop, the delivery of prograding deltaic sediments tapered off. This coincides with the disappearance of siderite concretions and the return of Neochonetes-dominated Biofacies 3 in sample GRR9A. This sample is composed of light gray shales with a few thin $(2-5 \mathrm{~cm})$ limestone beds. The light color of the shales and larger size of Neochonetes (mean size $=15.1$ $\mathrm{mm}$ measured at the greatest width, $\mathrm{N}=36$ in sample GRR9A compared to mean size $=7.9 \mathrm{~mm}$ measured at the greatest width, $N=102$ in samples GRR5A and 5B) suggest well-oxygenated conditions in this sample. Well-oxygenated conditions at the GRR outcrop are also evident in the overlying GRR9B interval. GRR9B contains successive shell pavements dominated by the pedunculate brachiopod Composita. During the formation of the Composita pavements, this environment was likely under the influence of local currents required by the suspension-feeding brachiopods with normal marine salinity. The numerous shells crowding the seafloor would 
have served as a trap for fine-grained sediments that were periodically delivered from the nearby terrigenous source. These episodes of sedimentation could have been survived by Composita individuals because they feed just above the substrate anchored by their pedicle, and they have the ability to eject nonfood particles from their feeding apparatus (Thayer, 1986). The surviving individuals would then have formed the next successive shell pavement by recolonizing the seafloor.

1.6.2.4. Regression 2...The final phase of relative sea level change is recorded in the samples FAIR4, FAIR5, ANMO4, and BELN2. These samples are composed of light to dark colored shales and contain either Biofacies 1 or Biofacies 2 (Figure 1-9). These occurrences of Biofacies 1 and 2 are the last marine fossil assemblage in the Ames Member just below an unfossiliferous, coarsening upward sequence associated with prodeltaic sedimentation. The stratigraphic position of the samples, along with their light color, indicates shallow-water deposition in a welloxygenated environment with increased turbidity. The occurrence of Biofacies 1 and 2 in both dark gray to black fissile shales (FAIR1B, 2, ANMO2, and GRR6A and 6B) and light-colored silty shales (FAIR4 \& 5, ANMO4, and BELN2) suggests that the dominantly molluscan taxa associated with these biofacies are strongly eurytopic with respect to terrigenous influx and oxygen availability. However, there is a slight difference in the taxonomic composition of the black shale samples and the light-colored shale samples that contain Biofacies 1 and 2. The uppermost light-colored shale samples (FAIR5, ANMO4, and BELN2) contain the infaunal suspension-feeding bivalve Anthraconia, whereas this taxon is absent in the black shale samples. This bivalve has been reported from nonmarine faunas in the Pennsylvanian of Illinois and Pennsylvania and indicates reduced salinities in these uppermost light-colored shale samples 
(Dickson, 1974; Eagar and Pierce, 1993).

The characteristics of the overlying conformable "post-Ames" sediments vary among the West Virginia sections. At the GRR exposure, the Ames marine zone is overlain by $0.6 \mathrm{~m}$ of thin to medium-bedded, fine-grained micaceous sandstone with abundant plant fragments. At the FAIR and ANMO outcrops, the Ames marine zone is capped by a thick $(\sim 5 \mathrm{~m})$ section of thinbedded, light-colored, unfossiliferous, fine-grained micaceous sandstones and siltstones with low angle $\left(<10^{\circ}\right)$ planar cross stratification, high angle $\left(>10^{\circ}\right)$ planar cross-stratification, and abundant organic material. These sedimentary features are typical of lower delta plain deposits (Coleman and Prior, 1982) and suggest that this interval was associated with a prograding distributary system. This interpretation is consistent with coarsening upward deposits that cap marine zones in Pennsylvanian sea level cycles elsewhere in the Appalachian Basin (e.g. Martino et al., 1996; Bennington, 1996; 2002).

\subsubsection{OXYGEN AVAILABILITY}

Donahue and Rollins (1974) previously cited low diversity as a criterion for a marginal marine interpretation of dark shales in the Ames Member. This interpretation does not take into account the possibility that low diversity assemblages restricted by low-oxygen conditions could mimic low diversity assemblages thought to indicate marginal marine conditions (Malinky and Heckel, 1998). Faunas that comprise Biofacies 1and 2 have several features in common with low diversity, Late Paleozoic dysaerobic communities described in Kammer et al. (1986). First, these faunas are dominated by vagile molluscs in terms of relative abundance. Although articulate brachiopods are present in lesser abundance, the assemblage does not resemble the typical aerobic, open shelf faunas dominated by stenohaline brachiopods, corals, and bryozoans 
elsewhere during this time. Second, the benthic component of these faunas is dominated by either deposit-feeding nuculid bivalves in Biofacies 1 or deposit-feeding microgastropods in Biofacies 2. Deposit feeders thrive in low oxygen environments that typically have a high organic content on, or within, the sediment. Lastly, the majority of specimens are much smaller than normal adult size for their respective species. Decreased body size may either reduce the oxygen demand required per unit volume of tissue by an organism or redirect metabolic processes away from growth to reproductive functions thereby increasing the number of offspring (Hallam, 1965; Mancini, 1978). Nuculids from dark shale samples containing Biofacies 1 are less than $2 \mathrm{~mm}$ in length at their greatest width, whereas many specimens recovered from light-colored shale samples are $1.5 \mathrm{~cm}$ at their greatest width.

Estuarine circulation in the Appalachian Basin apparently was a contributing factor that led to low-oxygen bottom waters in the Ames Embayment. However, the geographic position of the Appalachian Basin and a possible restricted connection between the Ames and the Midcontinent Seas could also have contributed to low-oxygen conditions. The Ames Embayment was isolated from the open ocean. This would have reduced open circulation and caused dissolved oxygen levels to continually decrease towards the basin floor (Rhodes and Morse, 1971). In addition, Boardman et al. (1984) hypothesized that the Appalachian Basin and the Midcontinent Basin were joined by a shallow-water connection during Glenshaw deposition, which may have dramatically reduced the abundance of nektonic cephalopods by restricting migration. A restricted connection would also have reduced the circulation of well-oxygenated surface waters in a situation analogous to the modern Black Sea "anoxic silled-basin" (Demaison and Moore, 1980). 


\subsubsection{CONCLUSIONS}

The results of Q-mode multivariate analysis were used to position groups of Ames Member samples from the northern Appalachian Basin along a continuum based on the proportional abundance of fossils. This form of indirect analysis aided in identifying the environmental gradient along which four marine biofacies were distributed. Biofacies are designated 1-4 and correspond to the distribution of taxa within four megaguilds: 1.

CRURI/INBIV (CRURI, INDEPBIV, and INSUSBIV) includes the eurytopic brachiopod Crurithyris, and infaunal deposit- and suspension-feeding bivalves; 2. GAST/SCA (BELLERO, EUPHEM, LOXONEM, PLEURO, SCAPHO) includes bellerophontid, loxonemitid, and pleurotomarid gastropods and the scaphopod Plagioglypta; 3. BRACH (CHONET, PEDUNC, PRODUCT, and STROPHO) includes the opportunistic Neochonetes, pedunculate, productid, and strophomenid brachiopods; and 4. STENO (BRYO, CEPHALO, CRINOID, and EPIBIV) includes stenotopic bryozoans, nektonic cephalopods, crinoids, and epifaunal bivalves. The environmental gradients are interpreted to represent changes in salinity, turbidity, and oxygen availability from the eastern (north-central West Virginia) margin to the western (central Ohio) margin of the Ames Embayment.

Lateral variations in the lithology and biofacies of the Ames are the result of differential subsidence associated with the contemporaneously-uplifted Appalachian Highlands. The eastern (north-central West Virginia) portion of the Ames depositional basin was deposited in a foredeep trough near terrigenous source areas. Biofacies 1and 2 occur exclusively in the eastern, clasticdominated, part of the Ames Member and are composed primarily of small $(<5 \mathrm{~mm}$ at greatest width) eurytopic molluscs and a few species of opportunistic brachiopods that were tolerant of high turbidity and variable salinity associated with these sources. The western (Ohio) portion of 
the Ames Member was deposited on a stable cratonic ramp with low turbidity and normal marine salinity. Biofacies 4 occurs exclusively in Ohio and is composed of stenotopic suspensionfeeding crinoids, brachiopods, and bryozoans.

Vertical variations of faunal assemblages in the Ames Member were the result of variations in relative sea level associated with glacio-eustatic cycles. Biofacies 3, dominated by Neochonetes, was deposited at the base of the Ames Member during the initial transgression in a mostly dysoxic environment with low turbidity and marine salinity. Neochonetes was an opportunistic, but otherwise stenotopic brachiopod capable of quickly colonizing the seafloor in response to changing conditions associated with transgression of the Ames Sea. During the first regression, low-density surface water from eastern terrigenous sources restricted vertical circulation, established a stratified water column, and promoted estuarine conditions in the Ames Embayment. Well-oxygenated surface waters were unable to circulate to the benthic habitat and led to periodically dysoxic conditions and the establishment of Biofacies 1 and 2, composed of diminutive eurytopic molluscs. A second, stratigraphically-higher occurrence of Biofacies 3 at the GRR, FAIR, and ANMO outcrops is interpreted to represent a second transgression; however, unlike the first transgression, lithologic and faunal data suggest that the benthic habitat was well-oxygenated. Above the mid-Ames marine zone occurrence of Biofacies 3, Biofacies 1 and 2 were deposited in the final regressive phase as local terrigenous source areas brought increasing turbidity and fluctuating salinity to the Ames Embayment.

In general, Ames biofacies do not correspond between the western Appalachian basin (southeastern Ohio) and the eastern Appalachian basin (north-central West Virginia). Variations in the rate of sea-level rise associated with glacio-eustatic cycles and differential subsidence rates within the Appalachian Basin result in variations during deposition of marine facies associated 
with a sea-level change, and on their preservation potential as well, leading to unpredictable facies relationships.

Fossil assemblages in the Ames have features in common with dysaerobic faunas in the Paleozoic. This suggests that low-oxygen conditions were periodically present in this area. Low-oxygen conditions are attributed to a stratified water column that restricted vertical circulation of well-oxygenated waters to the benthic habitat at different phases of the Ames sealevel cycle in north-central West Virginia. The first occurrence of low oxygen conditions coincides with the initial transgressive phase. Later occurrences of low oxygen conditions coincided with both mid-cycle and end-of-cycle regressions. 
Table 1-1: Locations of sampled outcrops.

\begin{tabular}{lcc}
\hline Sampled outcrop & County & UTM coordinates (zone 17) \\
\hline New Concord (CONC) & Guernsey, OH & 4426080N, 440800E \\
Belle Valley (BELL) & Noble, OH & $4403400 \mathrm{~N}, 452580 \mathrm{E}$ \\
Newport (NEW) & Washington, OH & $4360040 \mathrm{~N}, 478240 \mathrm{E}$ \\
Greenbag Road (GRR) & Monongalia, WV & $4386100 \mathrm{~N}, 591560 \mathrm{E}$ \\
Fairmont (FAIR) & Marion, WV & $4371680 \mathrm{~N}, 579220 \mathrm{E}$ \\
Anmore (ANMO) & Harrison, WV & $4342200 \mathrm{~N}, 560720 \mathrm{E}$ \\
Belington (BELN) & Barbour, WV & $4320800 \mathrm{~N}, 592810 \mathrm{E}$ \\
\hline
\end{tabular}


Table 1-2: Guild Composition

Bryozoans (BRYO): bryozoan colony fragments

Scaphopods (SCAPHO): Plagioglypta

Cephalopods (CEPHALO): Tainoceras and Metaceras

Crinoids (CRINOID): isolated crinoid fragments

Loxonemitid gastropods (LOXONEM): Donaldina, Pseudozygopleura, Meekospira,

Girtyspira, and Strobeus

Pleurotomarid gastropods (PLEURO): Glabrocingulum, Trepospira, Shanesiella

Bellerophontid gastropod (EUPHEM): Euphemites

Bellerophontid gastropods (BELLERO): Bellerophon (Bellerophon), Knightites

(Cymatospira),Knightites (Retispira), and Pharkidonotus

Infaunal Deposit feeding bivalves (INDEPBIV): Nuculopsis, Palaeoneilo, Paleyoldia, and Phestia

Infaunal Suspension feeding bivalves (INSUSBIV): Promytilus, Schizodus, Permophorus, Astartella, and Edmondia

Epifaunal bivalves (EPIBIV): Dunbarella, Aviculopecten, Acanthopecten, and Paleolima.

Chonetid brachiopod (CHONET): Neochonetes

Productid brachiopods (PRODUCT): Juresania, Hystriculina, Linoproductus, and Cancrinella Pedunculate brachiopod (CRURI): Crurithyris

Pedunculate brachiopods (PEDUNC): Composita and Neospirifer

Strophomenid brachiopods (STROPHO): Derbyia 
Table 1-3: Percent abundance of guilds and sample totals (N)

\begin{tabular}{|c|c|c|c|c|c|c|c|c|c|c|c|c|c|c|c|c|c|}
\hline & 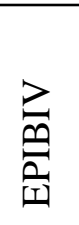 & 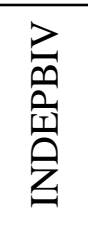 & $\begin{array}{l}Z \\
\text { D } \\
己 \\
n \\
Z\end{array}$ & 䛼 & 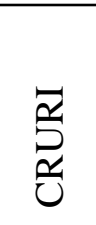 & 号 & 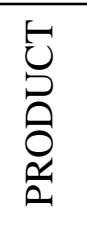 & 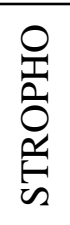 & $\begin{array}{l}\stackrel{0}{\not} \\
\stackrel{\sim}{n}\end{array}$ & $\begin{array}{l}\text { O } \\
\text { 空 } \\
\text { 空 } \\
\text { 空 }\end{array}$ & 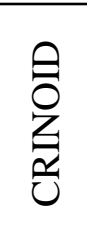 & 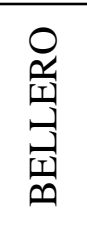 & $\begin{array}{l}\sum_{\mid=1} \\
\text { 至 } \\
\sum_{\Gamma=1}\end{array}$ & 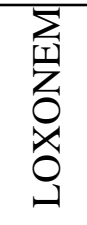 & 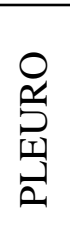 & 垔 & \\
\hline BEL & 0.0 & 0.7 & 0.0 & 5.7 & 14.5 & 5.7 & 0.7 & 0.0 & 3.0 & 0.0 & 68.2 & 0.0 & 0.0 & 0.0 & 1. & 0.0 & 296 \\
\hline & 2.6 & 0.0 & 0.0 & 10.2 & 0. & 3.0 & 9.5 & 0.0 & 0.3 & 0.0 & 72.4 & 1.0 & 0.0 & 0.0 & 0.3 & 0.0 & \\
\hline BELL3 & 0.0 & 0.0 & 0.0 & 44.7 & 0.9 & 0.0 & 4.5 & 0.0 & 11.1 & 0.0 & 37.2 & .0 & 0.0 & 0.0 & 1.5 & 0.0 & 33 \\
\hline $\mathrm{N}$ & 2.6 & .7 & 5.4 & 56.7 & 0.6 & 0.9 & 0.9 & 6.0 & 0.9 & 0.3 & 11.2 & 0.0 & 3.7 & 6 & 0.6 & 0.0 & 349 \\
\hline $\mathrm{BE}$ & 0.0 & 0.0 & 0.0 & 89.7 & 5.2 & 2.6 & 1.9 & 0.6 & 0.0 & 0.0 & 0.0 & 0.0 & 0.0 & 0 & 0. & 0.0 & 04 \\
\hline GR & 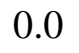 & 1.0 & 0.0 & 93.1 & 1.0 & 0.0 & 0.0 & 0.0 & .0 & 0.7 & 1.3 & .0 & 0.0 & 0 & 2.0 & 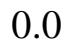 & t \\
\hline & 0.0 & 1.6 & 0.6 & 88.8 & 0.0 & 0.0 & 0.0 & 0.0 & 0 & 4.7 & 0.0 & .6 & 0.6 & 3 & 1.9 & 0.0 & 08 \\
\hline & 0.0 & .9 & 0.0 & 0.0 & 0.0 & 79.4 & 18.9 & 0.3 & 6 & .0 & 0.0 & .0 & 0.0 & .0 & 0.0 & . & 3 \\
\hline & 0.0 & 1.3 & 0.0 & 92.9 & 4.2 & 0.0 & 0.0 & 0.3 & 0 & 0.3 & 0.3 & .0 & 0.3 & 0 & 0. & 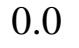 & 321 \\
\hline & 0.7 & 4.2 & 0.0 & 0.1 & 0.0 & .0 & 11.4 & 0.0 & 0 & .0 & 2.6 & 0.0 & 0.0 & 0 & 0. & 0. & \\
\hline & 0.0 & .8 & 0 & .6 & 8.0 & .0 & 1.7 & 0.0 & .0 & 1.1 & 0.4 & 1.5 & 0.7 & .2 & 2.0 & 0.0 & 53 \\
\hline & 0.0 & 3.6 & 0.3 & 74.0 & 4.6 & 0.0 & 0.0 & 3.0 & .0 & 0.0 & 1.0 & 1.3 & 3.0 & 7.2 & 2.0 & 0.0 & 30 \\
\hline & 1.0 & 2.3 & 0.3 & 77.9 & 0.0 & 0.0 & 0.0 & 0.0 & 0.0 & 0.7 & 0.0 & 1.0 & 2.3 & 12.4 & 2.3 & 0.0 & 30 \\
\hline $\mathrm{Al}$ & 0.0 & 3.7 & 0.6 & 55.6 & 0.0 & 0.0 & 0.0 & 0.0 & .0 & 0.0 & 0.0 & 2.8 & 5.3 & 28.9 & 1.9 & 1.2 & 32 \\
\hline & 0. & 1.0 & 0.0 & 37.5 & 0.0 & 0.0 & 0.0 & 0.0 & .0 & 0.0 & 0.3 & 2.3 & 0.7 & 3.4 & 3.9 & 1.0 & 3 \\
\hline A & 0.0 & 4.3 & 0.0 & 19.9 & 0.0 & 0.0 & 0.0 & 0.0 & .0 & 0.0 & 0.0 & 3.1 & 3.7 & 3.4 & 4.7 & 0.9 & 3 \\
\hline $\mathrm{F}$ & 0. & 12.7 & 0.0 & 8.2 & 0.0 & 0.0 & 0.0 & 0.0 & .0 & 0.0 & 0.0 & 2.1 & 4.1 & 3.5 & 3. & 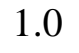 & 2 \\
\hline & 0. & 17.0 & 21.3 & 0.0 & 0.0 & 0.0 & 0.0 & 0.0 & .0 & 0.0 & 0.0 & 32.0 & 8.7 & 19.7 & 1. & 0.0 & 3 \\
\hline & 0.3 & 26.9 & 7.0 & 0.0 & 0.0 & 0.0 & 0.3 & 0.0 & .0 & 0.0 & 0.0 & 4.0 & 40.2 & 14.0 & 6.3 & 1.0 & 3 \\
\hline & 0.3 & 6 & 0.0 & 0.3 & 8.6 & 0.0 & 0.0 & 0.0 & 0 & 0.0 & 0.0 & 0.3 & 17.7 & 3.1 & 6. & 0.0 & 38 \\
\hline & 0.0 & 67.6 & 0.1 & 0.0 & 23.2 & 0.0 & 0.0 & 0.0 & 0.0 & 0.7 & 0.0 & 1.3 & 4.2 & 1.6 & 1. & 0.0 & 3 \\
\hline & 0.0 & & 0.0 & 1.6 & 38.1 & 0.0 & 0.0 & 0.0 & .0 & 1.9 & 0.0 & 4.7 & 4.4 & 0.0 & 2. & 2.2 & 320 \\
\hline IR5 & 2.2 & 32.2 & 2.5 & 8.5 & 36.3 & 0.0 & 2.5 & 0.0 & 0.0 & 3.5 & 0.0 & 0.6 & 2.8 & 6.0 & & 06 & 31 \\
\hline
\end{tabular}


Table 1-4: Percent abundance of megaguilds in the Ames marine zone.

\begin{tabular}{|c|c|c|c|c|}
\hline & STENO & BRACH & GAST/SCA & INBIV/CRURI \\
\hline BELL5 & 71.28 & 12.16 & 1.35 & 15.20 \\
\hline CONC & 75.33 & 22.70 & 1.32 & 0.66 \\
\hline BELL3 & 48.35 & 49.25 & 1.50 & 0.90 \\
\hline NEW1 & 14.90 & 64.47 & 10.89 & 9.74 \\
\hline BELL2 & 0.00 & 94.84 & 0.00 & 5.16 \\
\hline GRR9A & 2.96 & 93.09 & 1.97 & 1.97 \\
\hline GRR5B & 4.67 & 88.79 & 4.36 & 2.18 \\
\hline GRR9B & 0.59 & 98.53 & 0.00 & 0.88 \\
\hline FAIR3 & 0.65 & 93.18 & 0.65 & 5.52 \\
\hline ANMO3 & 3.27 & 91.50 & 0.98 & 4.25 \\
\hline GRR5A & 1.49 & 81.23 & 4.46 & 12.83 \\
\hline FAIR1A & 0.99 & 76.97 & 13.49 & 8.55 \\
\hline BELN1 & 1.63 & 77.85 & 17.92 & 2.61 \\
\hline ANMO1 & 0.00 & 55.59 & 40.06 & 4.35 \\
\hline FAIR2 & 0.33 & 37.46 & 61.24 & 0.98 \\
\hline ANMO2 & 0.00 & 19.88 & 75.78 & 4.35 \\
\hline FAIR1B & 0.00 & 8.22 & 79.11 & 12.67 \\
\hline ANMO4 & 0.33 & 0.33 & 65.45 & 33.89 \\
\hline BELN2 & 0.00 & 0.00 & 61.67 & 38.33 \\
\hline GRR6B & 0.26 & 0.26 & 27.86 & 71.61 \\
\hline FAIR4 & 0.65 & 0.00 & 8.50 & 90.85 \\
\hline GRR6A & 1.88 & 1.56 & 14.06 & 82.50 \\
\hline FAIR5 & 5.68 & 11.04 & 12.30 & 70.98 \\
\hline
\end{tabular}


Table 1-5: Summary of biofacies interpretations

\begin{tabular}{|c|c|c|c|}
\hline Biofacies & Salinity & Turbidity & \multirow{2}{*}{$\mathbf{O}_{2}$ availability } \\
\hline $\mathbf{1}$ & Variable & High & \multirow{2}{*}{ Oxic/Dysoxic } \\
\hline 2 & Variable/Marine & Moderate & \\
\hline 3 & Marine & Low & Oxic \\
\cline { 1 - 1 } & & & \\
\hline
\end{tabular}




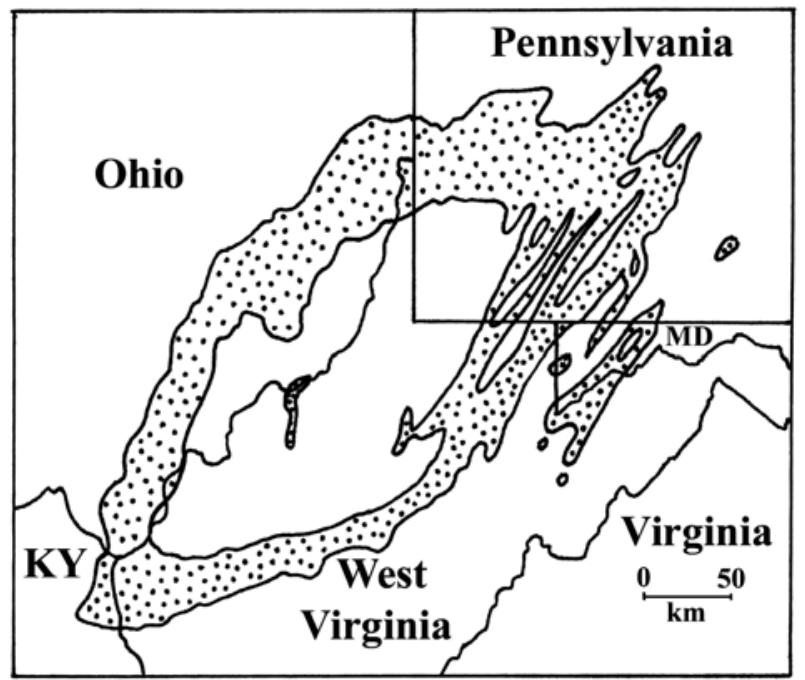

Figure 1-1. Distribution of the Conemaugh Group in the Appalachian Basin. The Ames Member is located near the middle of the outcrop belt. Data compiled from state geologic maps. 


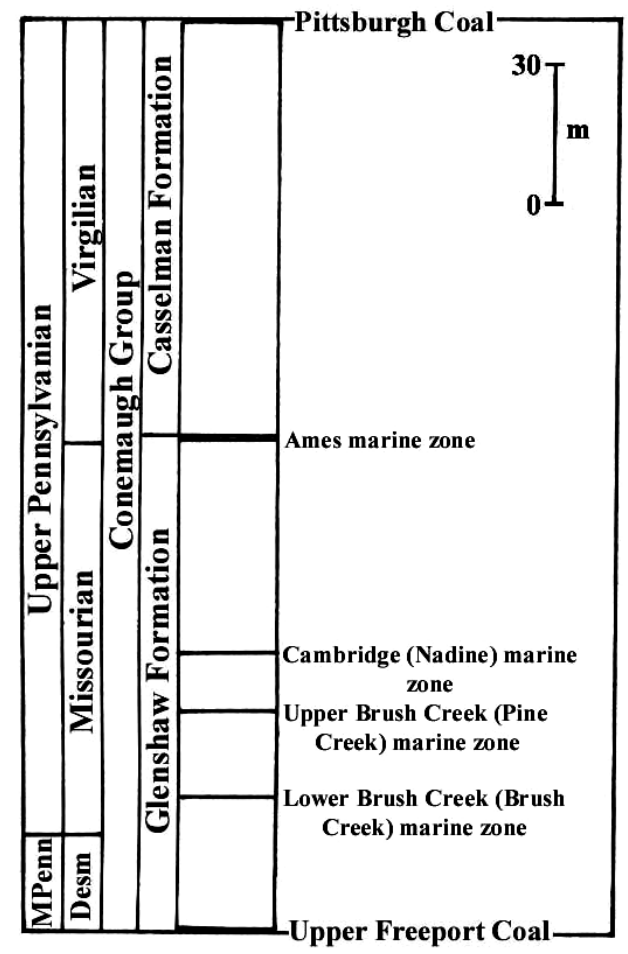

Figure 1-2. Generalized stratigraphic column of the Conemaugh Group with the position of major Glenshaw marine zones (modified from Edmunds et al., 1999). 


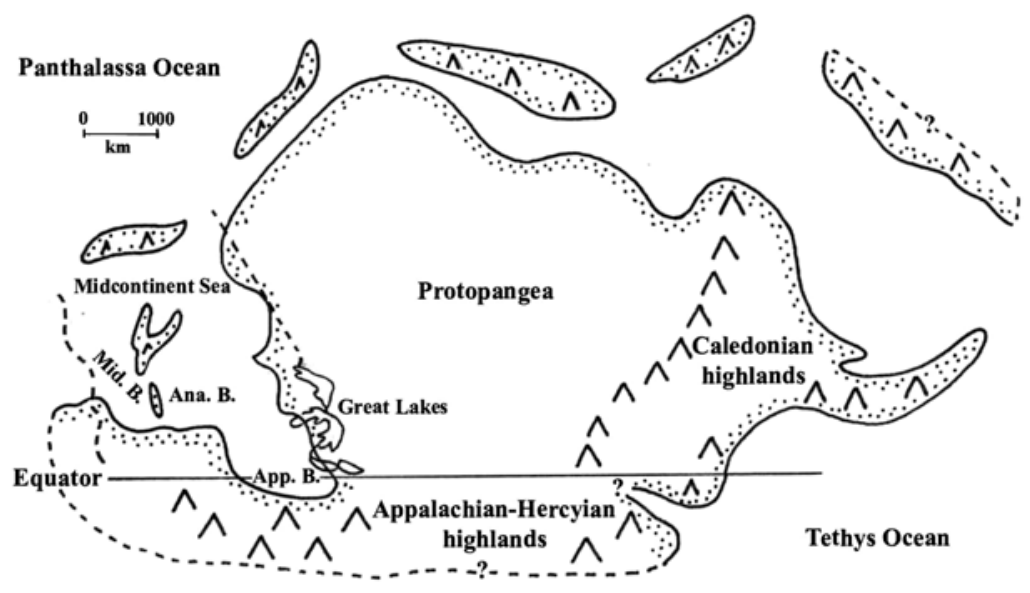

Figure 1-3. Interpreted paleogeography of the Euramerican part of Protopangea during the Late Pennsylvanian. The Great Lakes and portions of the north and south border of the present day United States (dashed lines) are included for reference. App. B = Appalachian Basin; Mid. B. = Midland Basin; Ana. B. = Anadarko Basin (modified from Heckel, 1995). 


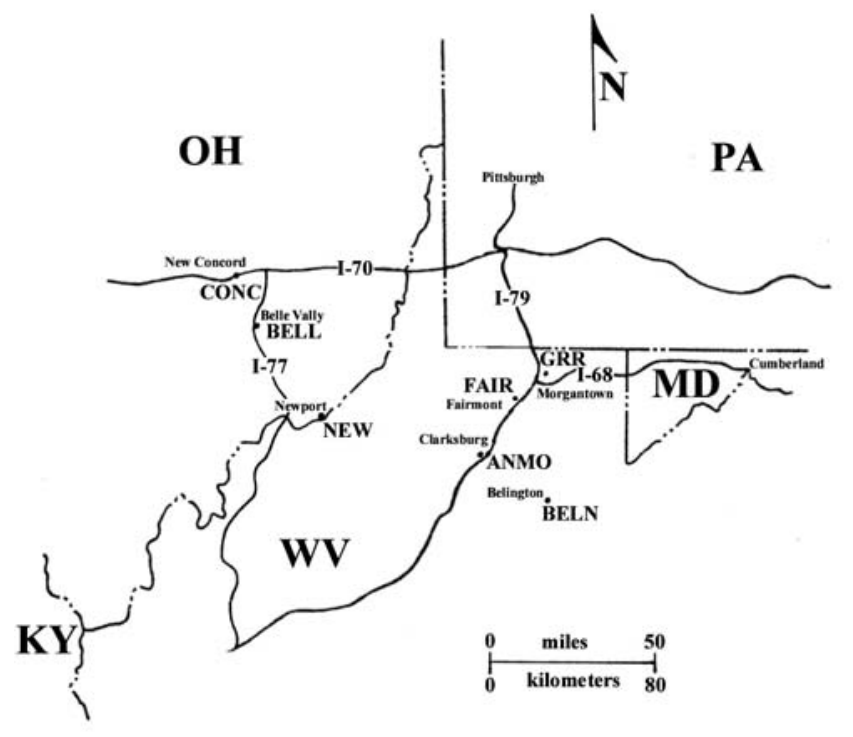

Figure 1-4. Map showing the locations of sampled Ames Member outcrops in the northern Appalachian Basin. Refer to Table 1 for outcrop abbreviations. 
Ohio samples
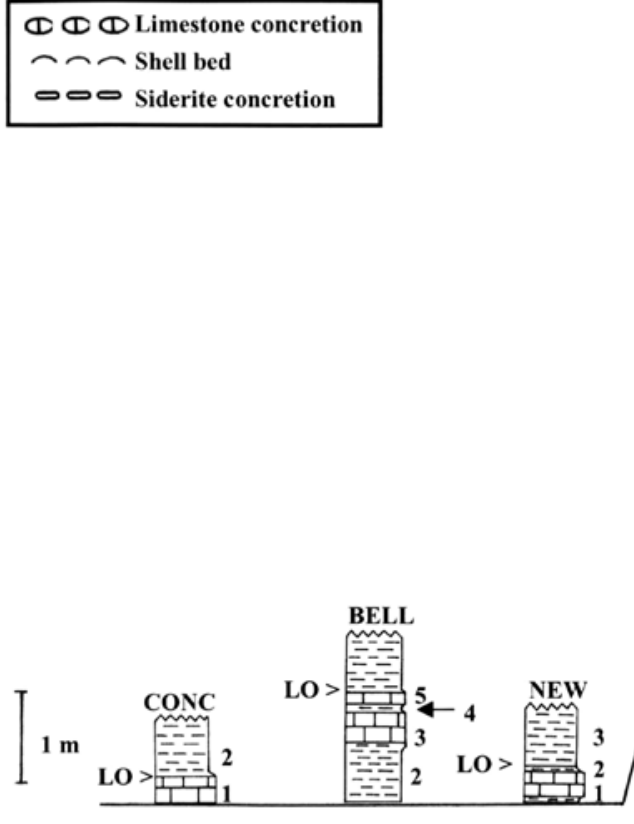

\section{West Virginia samples}

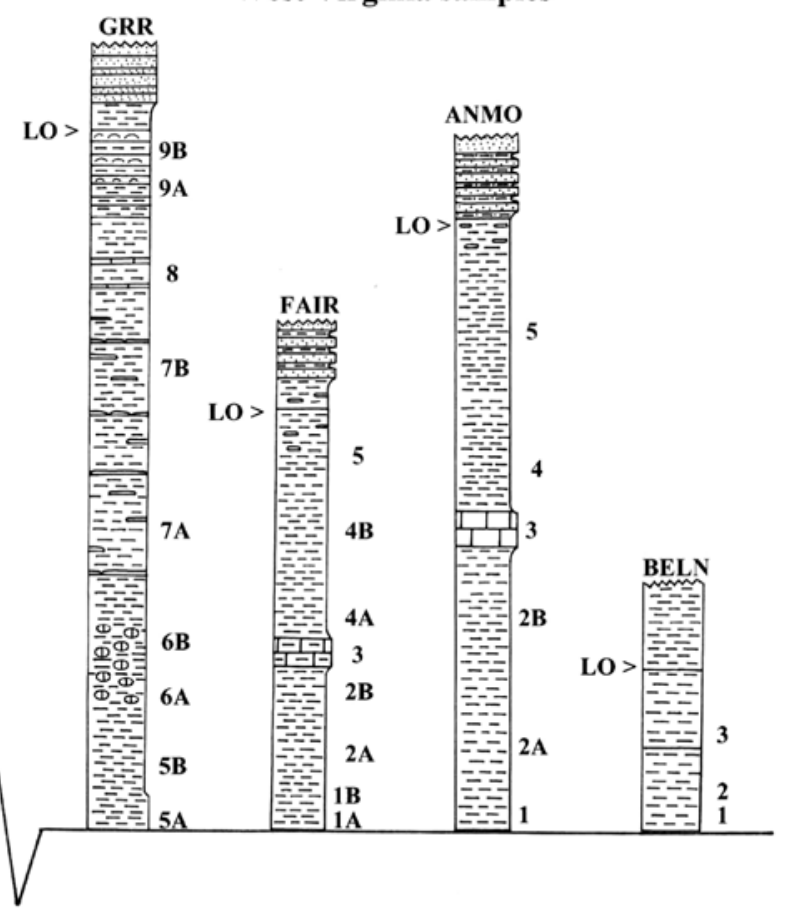

Figure 1-5. Stratigraphic distribution of the 35 Ames Member samples taken in the field. Stratigraphic datum is the pre-Ames surface (Harlem Coal where present). Horizontal break in the section represents the gap between surface exposures of the Ames Member in north-central West Virginia and southeastern Ohio. 


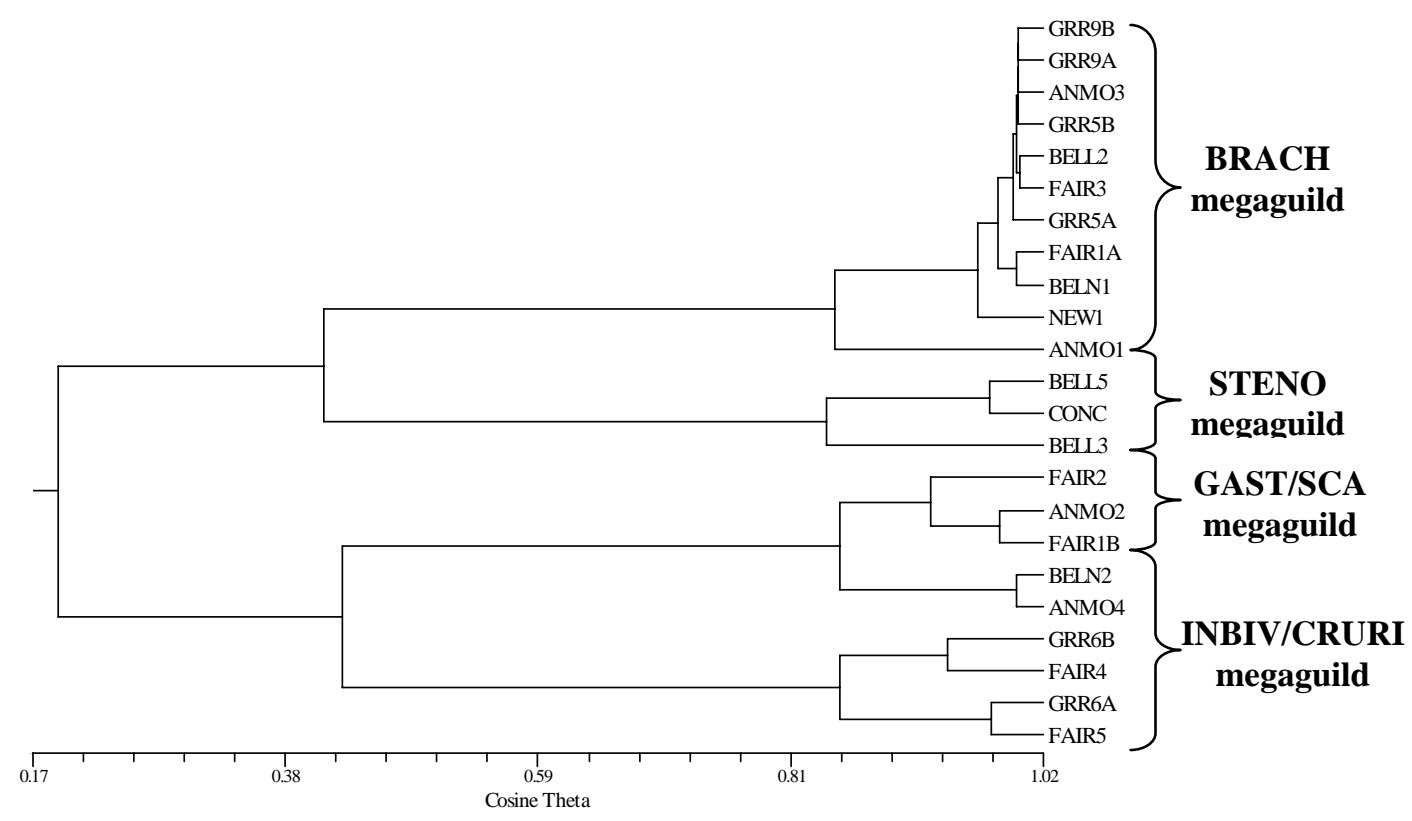

Figure 1-6. Q-mode dendrogram of Ames member samples. The samples are grouped into four clusters based on a high proportion of one of the four megaguilds defined in this study. 


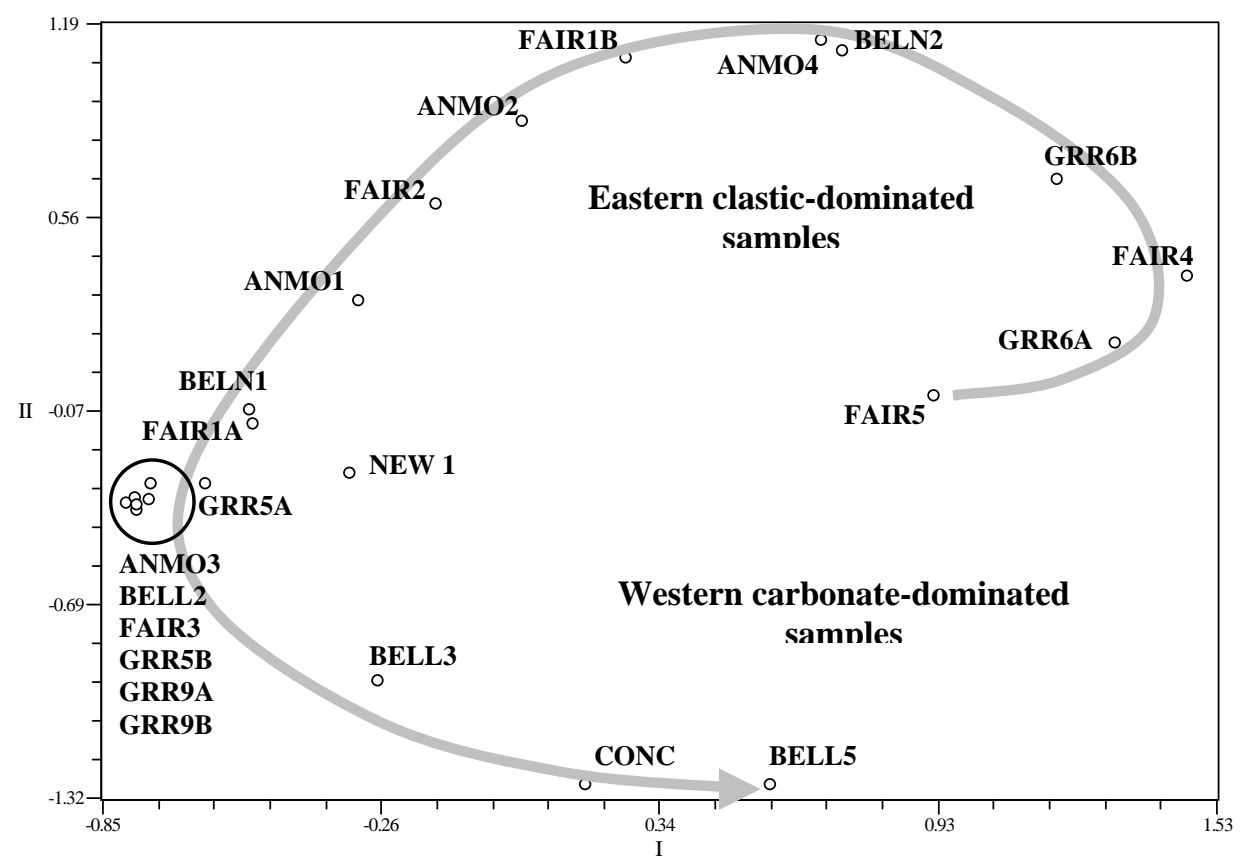

Figure 1-7. Q-mode multidimensional scaling (MDS) plot of Ames Member samples. Final stress $=0.06$, which is good to excellent (Rohlf, 1998). The hand-drawn arrow illustrates the environmental gradient associated with increasing distance from eastern clastic source areas. Gradients often plot in a arch-shaped pattern using ordination techniques such as MDS, as normally distributed variables, which are ditonic, are collapsed into a monotonic curve (Gauch, 1982). 


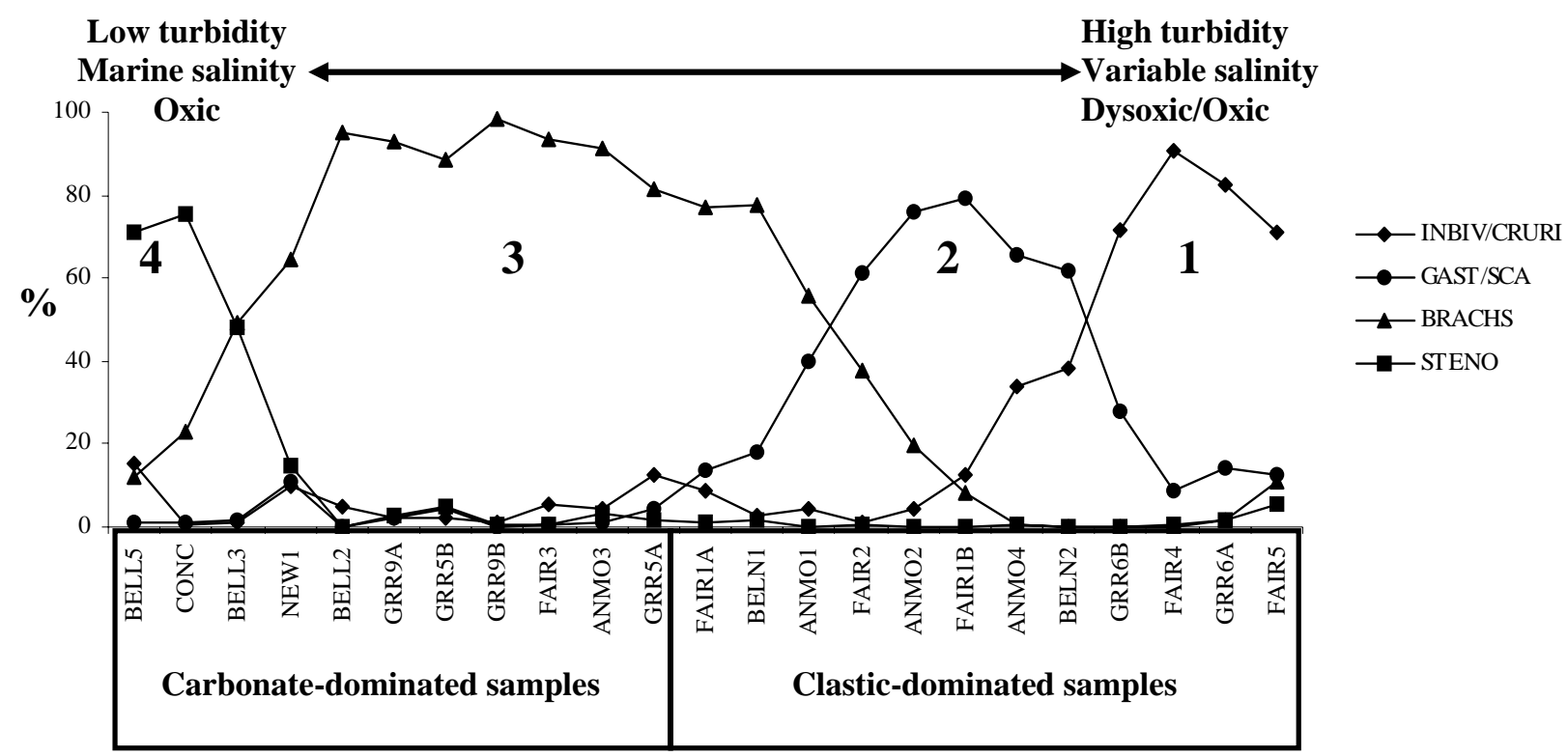

Figure 1-8. Percent abundance of the four most abundant megaguilds plotted along Ames Member samples. Samples have been arranged according to the results of Q-mode MDS analysis. Biofacies 1-4 are groups of samples having a common dominant guild deposited under similar conditions along an environmental gradient. The gradient is interpreted to represent changes in turbidity, salinity and oxygen availability with increasing distance from terrigenous sources along the eastern margin of the Ames Sea. Sample lithologies are also indicated to illustrate changes in the environment along the gradient. 


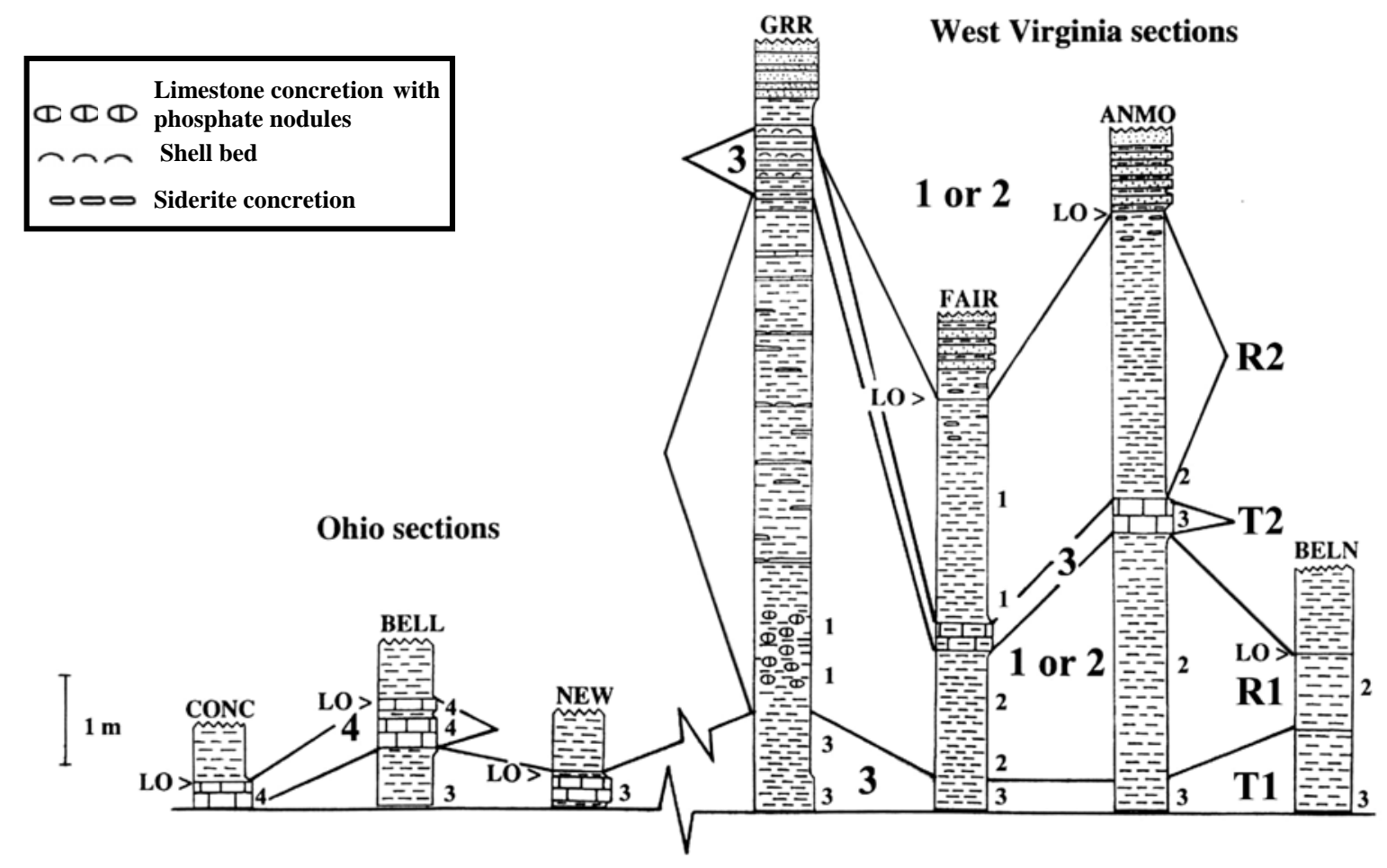

Figure 1-9. Stratigraphic distribution of the 23 final Ames Member samples assigned to Biofacies 1-4. Stratigraphic datum is the pre-Ames surface (Harlem Coal where present). Upper limit of biofacies distribution coincides with the last occurrence (LO) of marine fossils. Horizontal break in the section represents the gap between exposures of the Ames Member in north-central West Virginia and southeastern Ohio. Biofacies 1-4 have been correlated between outcrops where possible. Lines of correlation that contain more than one biofacies represent lateral facies changes associated with different environmental conditions. $\mathrm{T}=$ transgression, $\mathrm{R}=$ regression. 


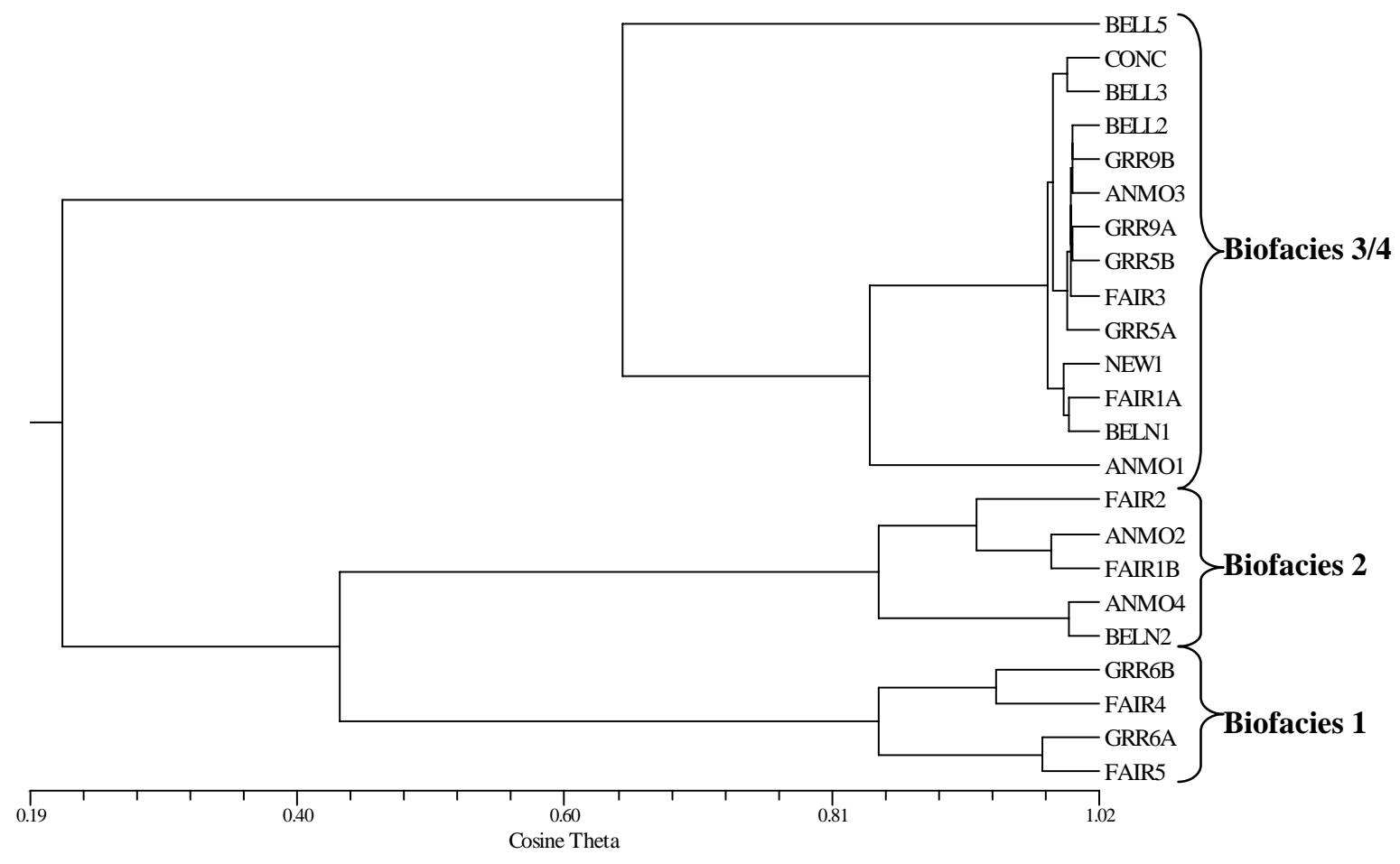

Figure 1-10. Q-mode dendrogram of Ames member samples without the abundance data for the CRINOID guild to determine if mixing the MNI and XNI counting methods affected the sample groups. Samples assigned to Biofacies 4 were positioned on the same cluster with samples assigned to Biofacies 3, which occupies a similar position along the environmental gradient in Figure 1-8. Clusters of samples assigned to Biofacies 1 and 2 were not affected by the counting procedures. 


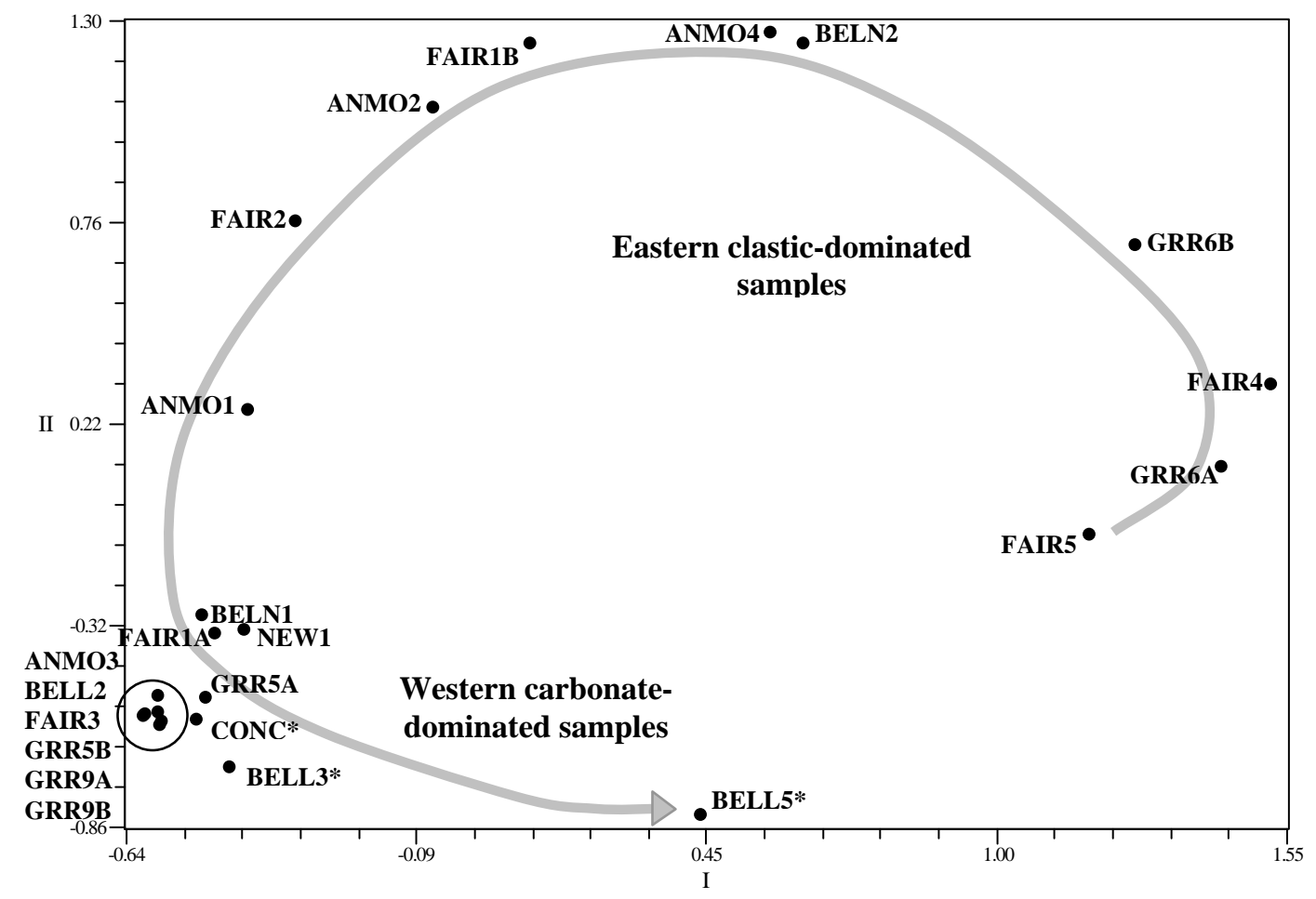

Figure 1-11. Q-mode MDS plot of Ames member samples without the abundance data for the CRINOID guild to determine if mixing the MNI and XNI counting methods affected the sample groups. Samples assigned to Biofacies 4 are highlighted with an asterisk and maintained a similar position along the environmental gradient recognized in Figure 1-8. The combined results of Figure 1-10 and 1-11 indicate that the mixing of MNI and XNI counting methods did not affect the position of samples along the environmental gradient in Figure 1-8. 
A

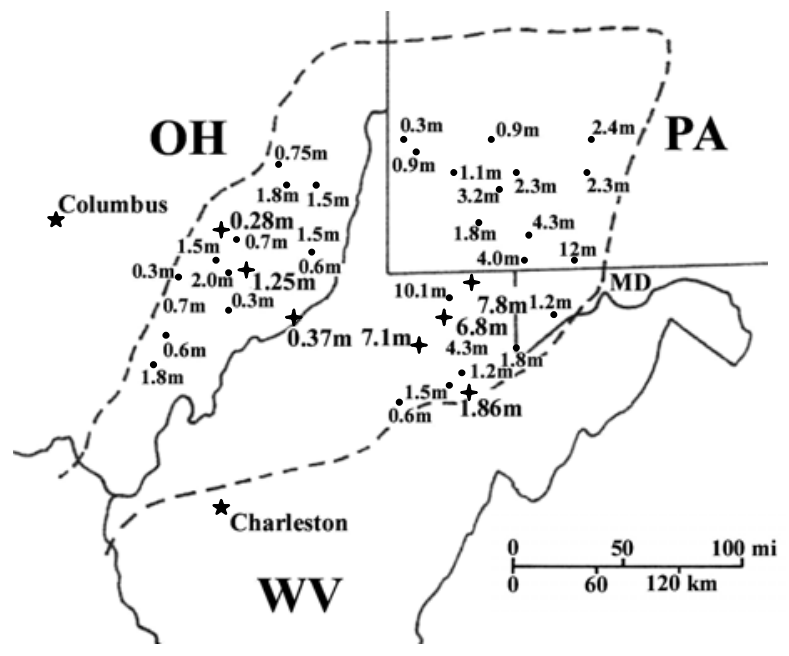

Data from Busch (1984)
+ Data from present study

B

Northwestern margin

Cratonic ramp

Southeastern margin Foredeep trough

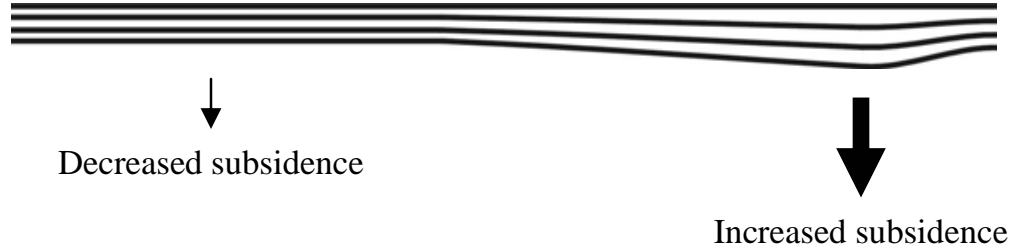

Figure 1-12. A. Map showing thickness of Ames marine zone. Thickness data are from Busch (1984) and the present study. Note increased thickness ( $>4 \mathrm{~m}$ ) in north-central West Virginia and adjacent southern Pennsylvania. B. Profile of the Ames depositional basin as a result of differential subsidence; no scale implied. Northwestern margin is proximal to the Cincinnati Arch, southeastern margin is proximal to the Appalachian Highlands. 
2.0.0.0. Degree of environmental stability as a primary control on biotic distribution: Gradient analysis of four marine zones within the Glenshaw Formation (Conemaugh Group, Upper

Pennsylvanian) in the Appalachian Basin

Joseph G. Lebold

\subsubsection{ABSTRACT}

The Upper Pennsylvanian Glenshaw Formation contains a series of marine zones that were deposited on the detrital slope of the Appalachian highlands during the last major transgressions from the Midcontinent Sea in the Paleozoic of eastern North America. These marine zones contain distinctive fossil assemblages characterized as biofacies that inhabited a variety of shallow-marine, carbonate- and clastic-dominated environments. Biofacies that contain a high abundance of opportunistic, paleoecologic generalists are characterized as eurytopic. These biofacies are dominated by infaunal and epifaunal deposit- and suspensionfeeding molluscs tolerant of periodic environmental fluctuations in salinity and turbidity associated with the activity of terrigenous source areas that contribute to environmental instability. Biofacies that contain a high abundance of paleoecological specialists are characterized as stenotopic. These biofacies contain a high percentage of epifaunal suspensionfeeding echinoderms, articulate brachiopods, bryozoans, and corals that preferred stable, normal marine conditions.

The degree of environmental stability fluctuated during the establishment of marine faunas in the Glenshaw Formation due to the rate of relative sea level change, the relative extent of the four major marine incursions, geographic position relative to the source of marine influence from the Midcontinent Sea, and variations in total accommodation space within the Appalachian Basin. Rapid transgression, a more extensive marine incursion, and close proximity to the source of marine influence increased environmental stability by buffering the benthic habitat from environmental fluctuations commonly associated with terrigenous sources. Whereas slow transgression, a less extensive marine incursion, and decreasing proximity to the marine source decreased environmental stability by increasing the influence of terrigenous sources on the benthic habitat. Greater accommodation space led to the deposition and/or preservation of a more complete sequence of biofacies. Whereas low total accommodation space hindered the deposition and/or preservation of eurytopic biofacies at the top of each marine zone. 


\subsubsection{INTRODUCTION}

Eight thin marine zones are distributed among thick sequences of nonmarine rocks within the Upper Pennsylvanian Glenshaw Formation in the northern Appalachian Basin (Busch, 1984; Busch and Rollins, 1984; Busch and West, 1987). These marine zones record the extent of marine incursions from the Midcontinent Sea onto the high shelf formed by the detrital slope of the Appalachian highlands (Heckel et al, 1998). Four of these marine zones are widespread and considered major transgressions within the Glenshaw Formation (Martino et al., 1996). These include (in ascending stratigraphic order with equivalent names for southwestern Pennsylvania in parenthesis); Lower Brush Creek (Brush Creek), Upper Brush Creek (Pine Creek), Cambridge (Nadine), and the Ames Members. Similar marine zones in the Pennsylvanian of the Midcontinent and Appalachian Basin are some of the most useful and reliable units for correlation (Bennington, 1996).

Periodic transgressions from the Midcontinent Basin resulted in the establishment of a variety of marine facies that have been the subject of several modern paleoecological studies (Glenshaw Formation: Merrill, 1986, Martino, 1996; Brush Creek Member: Shaak, 1972; Cambridge Member: Rollins et al, 1979; Ames Member: Donahue and Rollins, 1974, Rollins and Donahue, 1975, Nuhfer, 1979, Al-Qayim, 1983, Brezinski, 1983, Saltsmann, 1986, Merrill, 1993). Although these studies have identified biofacies thought to reflect changing conditions associated with variations in sea level, the role of environmental parameters such as dissolved oxygen, salinity, and turbidity in controlling faunal distribution are not well resolved.

The present study quantitatively measures lateral and vertical faunal variations in the Lower Brush Creek (Brush Creek), Upper Brush Creek (Pine Creek), Cambridge (Nadine), and the Ames Members of the Glenshaw Formation in four geographic areas in the northern 
Appalachian Basin. Wide spacing between the geographic areas was used to maximize lithologic and faunal variability, and therefore environmental variability, in the northern Appalachian Basin. In addition to the four geographic areas, data from Ames Member outcrops along a NW-SE trending transect (Lebold and Kammer, this volume, submitted) are included in this analysis as well. This provides an opportunity to examine a range of faunal and stratigraphic patterns during the deposition of the four most extensive marine events in the Upper Pennsylvanian. Faunal data are analyzed based on how individual taxa may have utilized available resources (e.g., food and habitat) under any given set of environmental conditions (Dodd and Stanton, 1990). The observed faunal patterns are combined with sedimentological data to interpret the range of paleoenvironmental conditions present in the Appalachian Basin.

\subsubsection{STRATIGRAPHY AND GEOLOGIC HISTORY}

The Conemaugh Group contains rocks deposited during the late Middle to Upper Pennsylvanian (Edmunds et al., 1999). Outcrops are located in southeastern Ohio, southwestern Pennsylvania, West Virginia, and eastern Kentucky in an elliptical belt (Figure 2-1) with the long axis oriented northeast-southwest. The Conemaugh is subdivided into two formations (Figure 22) including the Glenshaw Formation, which contains numerous thin marine zones distributed among nonmarine rocks, and the overlying Casselman Formation, which contains two limited marine zones, the Gaysport and the Skelly (Flint, 1965). The boundary between the two formations is located at the top of the uppermost marine zone in the Glenshaw Formation, the Ames Member composed of shale and limestone. Biostratigraphy of the Glenshaw Formation indicates that the four major marine zones, Lower Brush Creek (Brush Creek) through Ames Members, range in age from basal Missourian based on fusulinids (Smyth, 1974) and conodonts 
(Lane et al., 1971), to lowermost Virgilian (Lane et al., 1971, Wilde, 1975; Figure 2). Based on distinctive conodont faunas (Heckel et al., 1998), the Lower Brush Creek (Brush Creek) Member correlates with the Macoupin marine zone in the Illinois Basin and the Swope (Hushpuckney) marine zone in the Midcontinent Basin. The Upper Brush Creek (Pine Creek) Member correlates with the Shoal Creek marine zone in the Illinois Basin and the Dennis (Stark) marine zone in the Midcontinent Basin. The Cambridge (Nadine) Member correlates to the "Fithian"Flat Creek marine zone in the Illinois Basin and the Dewey (Quivira) in the Midcontinent Basin. Finally, the Ames Member correlates with the Shumway marine zone in the Illinois Basin and the Oread (Heebner) marine zone in the Midcontinent Basin.

Paleogeographic reconstruction (Figure 3-3) indicates that during the Middle to Late Pennsylvanian, the Appalachian Basin was positioned in the tropics and associated with the accreting "Protopangea" (Heckel, 1995). The basin was located longitudinally near the center of the landmass isolated from the larger Panthalassa and Tethys open tropical sea by about $4000 \mathrm{~km}$ (Heckel, 1995). It was located at the very eastern extent of the shallow, intermittent Midcontinent Sea, which also contained the small, deep and permanently marine Anadarko and Midland foreland basins. During deposition of the Middle to Upper Pennsylvanian units in the Appalachian basin, the major seaway that opened onto the midcontinent was located to the southwest (modern orientations), with the depositional axis oriented northeastward (Brezinski, 1983). The basin was bounded to the northwest by the Cincinnati Arch and to the southeast by the recently uplifted Appalachian highlands (Lamborn, 1951).

The alternating accretion and ablation of glaciers on Gondwana was initially cited as a mechanism for the deposition of Pennsylvanian cyclothems by Wanless and Shepard (1936). Extensive research during the last two decades has reasonably established glacial-eustatic sea 
level change as the primary control over Pennsylvanian marine cyclothems in the Midcontinent region of the United States (Heckel, 1986; 1995). Evidence for the glacial-eustatic model has received independent support by Crowell (1999), who concluded that glacial episodes on Gondwana persisted from the Late Mississippian to the Early Permian, and by Veevers and Powell (1987), who showed that the greatest inferred ice volume on Gondwana was attained during the Late Pennsylvanian when cyclothems are best developed in the Midcontinent region.

Late Middle to Late Pennsylvanian glacial-eustatic changes in sea level were controlled by climate change induced by orbital cyclicity (Heckel, 1986). The Glenshaw Formation was deposited in an 8 m.y. interval between $302 \pm 4$ Ma and $294 \pm 6$ Ma (Heckel, 2002). The average duration for the major to intermediate cycles of Heckel (1986) is about 400 k.y. (Heckel, 2002), which corresponds to the 400 k.y. Milankovitch secondary eccentricity, or stretch, cycle (Imbrie, 1985). Thus, the Lower Brush Creek (Brush Creek), Upper Brush Creek (Pine Creek), Cambridge (Nadine), and Ames Members, each as part of a major cycle, were each deposited in less than 400 k.y. The faunal variation within these marine zones is therefore the result of environmental controls rather than evolutionary processes, which generally are on the order of millions of years (Dodd and Stanton,1990).

\subsubsection{METHODS}

\subsubsection{Data}

Twenty outcrops located in the northern Appalachian basin were sampled in detail for paleoecological analysis (Table 2-1 and Figure 2-4). Sampling localities were selected on the basis of geographic position within the northern Appalachian Basin, accessibility to the outcrop, fossil abundance and variation, and stratigraphic completeness of the marine zone. The purpose 
of densely-sampling Glenshaw Formation marine zones in the Appalachian Basin was to focus on small-scale sedimentologic and paleoecologic variations in the data set that could then be related to specific environmental factors.

Because the focus of this study centers around the faunal variations during deposition of marine zones in the Glenshaw Formation, the lower sampling boundary was placed at the first occurrence of marine body fossils, which usually coincided with the top of a coal, where present. The upper sampling boundary was placed at the last occurrence of invertebrate body fossils. Once the upper and lower sampling boundaries were delineated, the marine zones were measured and described. 50 samples were taken using 3.7 liter capacity bags from Glenshaw marine zones among the four geographic areas in this study and combined with 35 samples taken from a NWSE transect of the Ames Member near the center of the northern Appalachian Basin. Samples were taken at each obvious change in lithology or wherever a distinct faunal change occurred. In order to account for the patchy distribution of animals observed in most living marine communities, small bulk samples were taken laterally across the exposures within the same sampled layer where possible. These small bulk samples were combined in the lab prior to processing. Whole limestone blocks were taken from the outcrops with stratigraphic orientation recorded on the rock. Most of the fossil-bearing units sampled for quantitative analysis represent low energy, mud-dominated (either carbonate or clastic) environments where no significant between-facies transport of shelly material would have occurred (Kidwell and Bosence, 1991). However, limestones from the BELL, and CONC outcrops southeastern Ohio contained sizesorted fossil grains and cross bedding indicating at least some transport of shelly material. Although for most benthic marine invertebrates, between-habitat transport of shelly material is rare in most settings, with exotic bioclasts composing only a minor component of most fossil 
assemblages (Kidwell and Flessa, 1995).

In the laboratory, the shale samples were washed, dried, and sieved. The use of surfactants to disaggregate the shales was abandoned early, due to breakage of thin shells and poor preservation of many of the fossils, especially molluscs. With the aid of a binocular microscope, the shale samples were carefully disaggregated and fossils were removed using a pin-vice and small dental picks. Limestone blocks were washed and fossils on the outer surface were counted and recorded. The blocks were then carefully broken into smaller pieces, and all observed taxa were tallied.

Abundance data of taxa are the sum of identifiable invertebrate fossils within 60 samples of major marine zones in the Glenshaw Formation (Appendix). Many of the original 85 samples taken from the marine zones were combined if they were stratigraphically adjacent and contained similar taxa or omitted if they were barren. A preferred minimum of 300 fossils was collected from each sample in order to determine the relative abundance of individual taxa (Dennison and Hay, 1967). At this sample size there is only a $5 \%$ probability that species with a $1 \%$ abundance will be missed, assuming no systematic bias by the observer. Species with a 3\% abundance have a probability of only $0.01 \%$ of being missed.

Brachiopod and mollusc fossil counts were derived using the MNI (minimum number of individuals) method for fragmentary remains (Gilinski and Bennington, 1994). Isolated bryozoan and echinoderm fragments were counted using the XNI (maximum number of individuals) method (Gilinski and Bennington, 1994). It is understood that using both methods in the same study will result in an overestimation of the number of bryozoan and crinoid individuals when compared to brachiopods and molluscs. However, the contribution of bryozoans and crinoids to the overall biovolume is significant. Their remains present important 
paleoecologic information regarding conditions during deposition. Tests to determine the effect of overestimating their abundance are presented later in the methods section (see Multivariate Analysis).

\subsubsection{Gradient Analysis}

Fossil assemblages tallied in the present study represent samples of populations that lived during deposition of the Glenshaw Formation. These assemblages are not classified as discrete community types (e.g. Johnson, 1962) because studies in modern ecology indicate that boundaries between community types are not always clearly defined (Whittaker, 1975). More often, community boundaries overlap as species respond to the physical environment and competitive pressure from other species that inhabit similar environments. This pattern relies on strong independence between species consistent with the individualistic hypothesis of species distribution proposed by Gleason (1926). In this hypothesis, species are distributed along environmental gradients, each reacting to physical changes independently. Changes in species distributions are a response to different physical conditions along these gradients.

Two related methods are available to analyze how species are distributed along a gradient: direct and indirect gradient analysis. In direct gradient analysis, samples are taken along a defined environmental gradient, such as elevation or temperature. Indirect gradient analysis arranges samples along a gradient based on taxonomic composition. Differences in samples can be related to various environmental factors regardless of their geographic or stratigraphic position. Indirect gradient analysis was chosen for this study because marine zones in the Glenshaw Formation rarely show simple lateral or vertical facies gradients on outcrop scale appropriate for sampling. 
To analyze the distribution of fossil assemblages along gradients, taxa were placed into guilds based on the habitats and trophic preferences of fossil organisms (Table 2-2). Combining fossil organisms into groups based on their autecological similarities is the basis of the guild concept (Bambach, 1983). Bambach (1983) extended the modern ecological application of the guild concept, which focuses on intraspecific competition for resources and constructed groups based on taxonomic position and autecology. Combining taxa into groups reduces the number of variables per sample and improves the signal to noise ratio of ecologic patterns by increasing the relative magnitude of each grouped variable (Kammer and Lake, 2001). This reduces the dimensionality of the data set so that patterns within the data are more easily recognized (Gauch, 1982).

\subsubsection{Multivariate Analysis}

Cluster analysis and minimum-spanning tree (MST) were used to explore and identify patterns within samples (Q-mode) utilizing the software package NTSYSpc-2.02i (Rohlf, 1998). Hierarchical, agglomerative cluster analysis produces a dendrogram of objects that corresponds to the degree of similarity between objects. Objects with the highest degree of similarity are grouped together first. The next most similar objects are then successively connected to these until all objects and groups are tied together at progressively lower levels of similarity. For this study, clustering was performed using the "unweighted pair-group method with arithmetic averaging" (UPGMA). The similarity index used for the Q-mode analysis was cosine theta, which is the appropriate similarity coefficient for Q-mode analysis (Joreskog et al., 1976). A drawback to divisive techniques like cluster analysis is that objects are placed into discrete groups whether they exist in the data set or not. Inappropriate groupings can be constructed in 
data that are oftentimes gradational in nature. To aid in identifying the presence of an underlying gradient among samples, a minimum-spanning tree was constructed. A MST is a nearestneighbor plot that links objects (variables) together with the greatest similarity, links all objects together with at least one other object, and minimizes the distances between all objects (Warshauer and Smosna, 1981). The order of samples from the calculated tree can be used to order samples within clusters and determine the relationship between clusters.

Multivariate analysis was also used to determine if guilds counted using the XNI counting method were masking the ecological signal of guilds counted using the MNI method. Q-mode cluster analysis was performed on the relative abundance of data with and without crinoids. The CRINOID guild was chosen for this test because of the taxa counted using the XNI method, only the crinoids were present in samples with numbers comparable to brachiopod and mollusc guilds. If the crinoids are indeed masking the influence of other guilds, then samples with abundant crinoids would be distributed randomly among the remaining sample groups when crinoids are excluded. If crinoids are not masking the ecological signal of the other guilds, then samples that originally contained abundant crinoids should cluster together or be grouped with samples dominated by guilds that have similar environmental preferences.

\subsubsection{RESULTS}

\subsubsection{Faunal Patterns within Glenshaw Marine Zones}

A total of 19,247 fossils were tallied in the 60 final samples derived from the 85 field samples (Appendix). The data were normalized to percent abundance to offset the effect of combining stratigraphically adjacent samples with similar assemblages, which resulted in widely uneven total fossil counts between samples (N, Appendix). Analysis of the relative abundance data revealed clear patterns in the distribution of the 16 guilds. These patterns were enhanced 
when guilds were placed into five Bambachian megaguilds (Droser et al., 1997) based on similar distribution within samples that suggested similar environmental preferences. Megaguilds (Table 2-3, listed with assigned guilds defined in Table 2-2) are: INBIV (INDEPBIV, INSUSBIV and SPIROR), which includes the infaunal deposit- and suspension-feeding bivalves, and the polycheate worm Spirorbis; GAST/SCA (BELLERO, EUPHEM, LOXONEM, PLEURO, SCAPHO), which includes bellerophontid, loxonemitid, and pleurotomarid gastropods and the scaphopod Plagioglypta; BRACHS (CHONET, PEDUNC, PRODUCT, and STROPHO), chonetid, pedunculate, productid, and strophomenid brachiopods; STENO (BRYO, CEPHALO, CORAL, CRINOID, EPIBIV, and TRILO), stenohaline bryozoans, cephalopods, solitary rugose corals, crinoids, epifaunal bivalves, and trilobites. Epifaunal bivalves commonly co-occurred with these groups and were placed into the STENO megaguild; and CRURI, the pedunculate brachiopod Crurithyris. Each megaguild has a peak abundance among samples and declines on either side which indicates an individualistic response to a particular set of environmental conditions (Table 2-4). Overlap in the distributions indicates that discrete faunal assemblages are not present and that intergrading faunal assemblages exist, making the placement of samples into groups somewhat arbitrary. For example, samples BELL3, AMH1, and FAIR5 have a nearly equal proportion of fossils from two different megaguilds and were tentatively assigned along the border of two megaguild groups (Table 2-4). While this reflects practical limitations when placing objects (samples) that exist along a continuum into groups, it does not overshadow the usefulness of assigning samples to a particular faunal type (e.g., nearshore fauna and offshore fauna) when describing faunas (Gauch, 1982).

An interesting feature of the sample groups recognized in the relative abundance data is that each group, defined by megaguild abundance, contains samples from more than one marine 
zone. This indicates that similar sets of environmental conditions were established during each marine transgression. Therefore, because these groups are not stratigraphically defined (from a single marine zone), this analysis will initially be conducted with all Glenshaw Formation samples pooled together. The samples will be subdivided stratigraphically and geographically at a later point in this analysis based on similar features interpreted as primary controls on faunal distribution.

Q-mode cluster and MST analyses were performed to more rigorously examine the sample groups recognized in the relative abundance data (Table 2-4). Cluster analysis produced five distinct clusters of Glenshaw Formation samples that corresponded to the five megaguilds (Figure 2-5). Only two samples, FAIR2 and AMP1A, did not fall into the megaguild groups evident in the relative abundance data suggesting that the group boundaries are gradational. MST analysis was then used to help elucidate the gradational nature of Glenshaw Formation sample groups. MST produced a linked series of the five groups identified in cluster analysis that illustrates the relationship between the clusters (Figure 2-6). MST also placed samples FAIR2 and AMP1A on the boundary of the group it was assigned to by cluster analysis (Figure 2-5) and the preliminary group defined in the analysis of megaguild percentages (Table 2-4). These borderline samples were assigned to the group originally defined during preliminary analysis of the relative abundance data.

In order to determine the nature of the gradient identified by MST, Glenshaw samples were plotted along a horizontal axis based on their respective position along the MST (Figure 26). Groups of samples are distinguished by the dominance of a different megaguild, which accounts for the greatest percentage of taxa in a given sample group. Each group displays an approximate bell-shaped, or Gaussian, distribution, which mirrors a similar pattern recognized in 
the numeric data (Table 2-4). This indicates that each megaguild, was successful within a specific set of environmental conditions, but was displaced by another megaguild under a different set of conditions along the gradient. Thus, the resultant sample groups each contain a distinct fossil assemblage that can be characterized as a biofacies. Biofacies are labeled 1-5 in the order that they appear along the environmental gradient (Figure 2-7A).

\subsubsection{Glenshaw Biofacies}

2.4.2.1. Biofacies 1... This biofacies is characterized by the INBIV megaguild (Table 2-3). Within this megaguild, the INDEPBIV guild is the most abundant and is composed primarily of the bivalve Nuculopsis, which accounts for $40 \%$ of the fossils in Biofacies 1 . Other taxa that are present in significant numbers include the GAST/SCA and CRURI megaguilds which account for $22 \%$ and $12 \%$, respectively. Samples assigned to this biofacies are composed exclusively of shales that vary in color from light gray to black.

Biofacies 1 represents a eurytopic faunal assemblage tolerant of variable salinity and turbidity levels associated with terrigenous sources (Table 2-5). In Midcontinent faunas, increased clastic influx and reduced salinities caused by runoff from terrigenous sources commonly favor eurytopic molluscs (Boardman et al., 1984). Infaunal bivalves are particularly well-suited to increased turbidity because they live and feed within the sediment. Increased turbidity produces a soft substrate by continually adding water-saturated sediments. The occurrence of the brachiopod Crurithyris in Biofacies 1 is consistent with previous research that concluded Crurithyris was strongly eurytopic with respect to turbidity and fluctuating salinity (Brezinski, 1983).

A unique faunal assemblage was collected from sample LBCH2. This assemblage is 
characterized by a large proportion (> 67\%) of the serpulid worm, Spirorbis. The INBIV and GAST/SCA guilds account for nearly $18 \%$ and 15\%, respectively, of fossils collected from this sample. Serpulid worms are suspension-feeding organisms that live in a calcareous tube (Rouse and Pleijel, 2001). Recent and fossil serpulids are known to tolerate a variety of environmental conditions including salinities that range from marine to freshwater (Rouse and Pleijel, 2001). Large buildups constructed of intertwined tubes occur mainly in enclosed embayments or in brackish water habitats (Bianchi and Morri, 1996) as well as near submarine freshwater springs (Cocito et al., 2004). The association of serpulid worms with infaunal bivalves and gastropods in this sample of Biofacies 1 suggests that this environment was subject to periodic episodes of freshwater influx that promoted brackish-water conditions.

With the exception of sample LBCH4, all samples assigned to this biofacies were taken from either dark gray or black shales. Abundant organic matter within the sediment commonly produces shales that are dark in color (Demaison and Moore, 1980). The high concentration of organic material in the sediment could have been derived from two sources. Many of the dark shale samples in this study contained identifiable plant fragments that were most likely transported from terrestrial environments and deposited near source areas. The other likely source of organic material could be related to increased primary productivity by photosynthesis (Dodd and Stanton, 1990). Limiting factors for photosynthesis are light and nutrient availability. However, some forms of algae can photosynthesize to depths of $250 \mathrm{~m}$ (Wray, 1977). In the relatively shallow (on the order of 10's of meters) seas that occupied the Appalachian Basin during Glenshaw times, light availability was presumably not a limiting factor. Nutrient availability was most likely a major contributor to primary productivity. The most likely source would have been terrestrial runoff, which commonly contains a high concentration of dissolved 
nutrients (Boardman et al, 1984, Elias and Young, 1998). The preservation of abundant organic material in the sediment requires a limited oxygen supply that would otherwise oxidize the organic matter (Demaison and Moore, 1980).

In addition to the dark color of the shales, most individuals of Nuculopsis are very small $(<2 \mathrm{~mm})$, deposit-feeding nuculid bivalves that are commonly associated with faunas in oxygen deficient basins (Kammer et al., 1986). Decreased body size may either reduce the oxygen demand required per unit volume of tissue by an organism or redirect metabolic processes away from growth to reproductive functions thereby increasing the number of offspring (Hallam, 1965; Mancini, 1978). The brachiopod Crurithyris has also been identified as eurytopic with respect to oxygen (Malinky and Heckel, 1998; Olszewski and Patzkowski, 2001).

2.4.2.2. Biofacies 2...This biofacies is characterized by the GAST/SCA megaguild (Table 2-3). Within this megaguild, the gastropod guilds (in descending order of abundance) LOXONEM, EUPHEM, PLEURO, and BELLERO compose nearly 57\% of the fossils, and the SCAPHO guild has its highest abundance, $0.9 \%$, in Biofacies 2. Other guilds present include the CHONET and INDEPBIV guilds that comprise $18 \%$ and $10 \%$ of Biofacies 2, respectively. Similar to Biofacies 1, samples assigned to Biofacies 2 are composed exclusively of shales that range from light to dark gray in color.

Very little documentation is available concerning the habitat of Paleozoic gastropods. Many Paleozoic gastropods, similar to the specimens in the present study, are found in dark, fine-grained sediments, which contradicts modern analogs that indicate gastropods are strictly herbivores limited to clear water environments with firm substrates (Peel, 1978). Their occurrence in dark, fine-grained sediments has led several researchers to conclude that many 
Paleozoic gastropods were deposit feeders (Aigen, 1974; Rollins et al., 1979).

With the exception of the ANMO4 sample, all Biofacies 2 samples were recovered from dark gray and black shales. The dark color of these shales is attributed to increased organic material that contributed to the dark color of shales in Biofacies 1. In addition, four of the six samples are dominated by high-spired microgastropods that are usually less than $5 \mathrm{~mm}$ in height. Microgastropods are thought to be opportunistic, eurytopic taxa that commonly dominate lowoxygen settings during the Carboniferous period (Fraiser and Bottjer, 2004).

Biofacies 2 represents a eurytopic faunal assemblage tolerant of fluctuations in oxygen availability and moderate terrigenous influx (Table 2-5). The distribution of Biofacies 2 along the gradient overlaps the distributions of Biofacies 1 on one side and Biofacies 3, composed of the BRACH megaguild, on the other side. Overlap with Biofacies 1 suggests that the GAST/SCA megaguild was less tolerant of terrigenous influx than Biofacies 1 but more tolerant of these conditions than the generally stenohaline, suspension-feeding BRACH megaguild that characterizes Biofacies 3. The switch in dominance from infaunal deposit-feeding bivalves to semi-infaunal to epifaunal deposit-feeding gastropods suggests a reduction in turbidity. Reduced turbidity would permit previously deposited muds to compact, increasing substrate firmness, and promote the accumulation of organic detritus on the substrate. Epifaunal deposit feeders would benefit from both a firmer substrate for locomotion and the accumulation of organic detritus as a readily available food source.

2.4.2.3. Biofacies 3... This biofacies is characterized by the BRACH megaguild (Table 2-3). However, the CHONET guild, composed of the chonetid brachiopods Neochonetes and Chonetinella comprise the overwhelming majority of fossils recovered from this biofacies, 
accounting for nearly $72 \%$ of the fossils. The other brachiopod guilds, PEDUNC, PRODUCT and STROPHO comprise less than $9 \%$ of the fossils. Biofacies 3 is found in samples that range from light and dark colored shales that commonly contain limestone nodules to bedded limestones.

Previous research indicates that chonetid brachiopods employ an opportunistic life strategy. Opportunists, or r-strategists, are environmental generalists that produce many offspring and can rapidly increase their numbers under the appropriate environmental conditions (Levinton, 1970). In particular, Neochonetes and Chonetinella have been associated with rapidly changing conditions often attributed to rapid marine transgressions within Pennsylvanian sea level cycles (Jacobs, 1976; Rollins et al., 1979; Brezinski, 1983; Saltsmann, 1986; Merrill, 1993; Bennington, 1996; Malinky and Heckel, 1998).

Biofacies 3 represents a predominantly opportunistic, stenotopic faunal assemblage. The position of Biofacies 3 along the gradient between the eurytopic Biofacies 2 and the stenohaline suspension-feeders in Biofacies 4 suggests that samples assigned to this biofacies were deposited in a normal marine environment subjected to low terrigenous influx (Table 2-5). Chonetid brachiopods have commonly been associated with normal marine conditions within Pennsylvanian cyclothems (e.g., Nuhfer, 1979; Brezinski, 1983; Boardman et al.,1984; Malinky and Heckel, 1998; Olszewski and Patzkowski, 2001). Minor amounts of turbidity would not have been particularly harmful to this biofacies because articulate brachiopods have the ability to remove a limited amount of excess sediment from their feeding structures (Thayer, 1986).

2.4.2.4. Biofacies 4... This biofacies is characterized by the STENO megaguild (Table 2-3). Within this biofacies, the CRINOID guild accounts for nearly $65 \%$ of the fossils recovered from 
these samples. The BRYO, CEPHALO, EPIBIV, TRILO, and CORAL guilds combined account for $12.5 \%$ of the remaining fossils. Biofacies 4 occurs most commonly in bedded limestone samples but is also found within light to dark gray calcareous shales that often contain limestone nodules.

The abundance of bryozoans, articulate brachiopods, cephalopods, corals, and trilobites, indicates that this environment was deposited under normal marine conditions with minimal turbidity (Table 2-5). These taxa are stenohaline organisms with few exceptions (Kammer and Lake, 2001) and are predominantly suspension feeders (except TRILO) that require low turbidity in the water column to obtain food (Aller and Dodge, 1974). The abundant crinoids and brachiopods in Biofacies 4 make this assemblage most similar to the moderate-depth stenotopic communities recognized by Boardman et al. (1984) that were deposited in well-oxygenated environments with normal marine salinity.

2.4.2.5. Biofacies 5... This Biofacies is characterized by the dominance of the pedunculate brachiopod Crurithyris which accounts for $73 \%$ of the fossils. The CRINOID guild is also present in significant numbers and accounts for $14 \%$ of the remaining fossils, although their numbers continually decrease away from the STENO distribution. This biofacies is found in samples that range from light and dark colored shales to bedded limestones.

Crurithyris has been classified as a strongly eurytopic taxon that was capable of tolerating increased terrigenous influx and fluctuating oxygen availability. However, the specific conditions that Crurithyris could tolerate have not been defined. The use of gradient analysis provides some indication on the specific environmental preferences of Crurithyris. The transition from stenotopic, epifaunal, suspension-feeders in Biofacies 4 to eurytopic epifaunal, 
suspension-feeders in Biofacies 5 suggests that conditions varied along the gradient, but only with respect to salinity. Both Biofacies 4 and 5 have similar trophic (suspension-feeding) and habitat (attached, epifaunal) preferences that suggests that there was only a minor increase in turbidity that did not dramatically affect the consistency of the substrate. Therefore, the transition from Biofacies 4 to Biofacies 5 suggests an increase in salinity fluctuations independent of an appreciable increase in turbidity levels (Table 2-5).

The results of cluster analysis indicate that mixing MNI and XNI counting procedure did not severely affect the grouping of samples with a high abundance of the CRINOID guild. Of the 18 samples assigned to Biofacies 4, seven grouped with the stenotopic Biofacies 3 , five formed a new group between Biofacies 3 and Biofacies 5, and two grouped at low similarity with Biofacies 5. The position of these 14 samples did not change significantly and were positioned along the gradient with, or adjacent to, samples interpreted as well-oxygenated, normal marine environments with low turbidity. Four of the 18 samples grouped at low similarity with Biofacies 2 where it overlaps with Biofacies 3. However, conditions along this portion of the gradient are still within normal marine conditions with a moderate increase in turbidity.

\subsubsection{GRADIENT INTERPRETATION}

The degree of environmental stability is thought to be an important factor in determining the composition and structure of faunas (Dodd and Stanton, 1990). Environmental fluctuations generally associated with terrestrial runoff appear to increase the degree of environmental instability (Hallock, 1987; Wood, 1993). These fluctuations are largely due to variations in the influx of terrestrial runoff, which can affect parameters such as sedimentation rate (turbidity), salinity, oxygen level, and $\mathrm{pH}$ levels and tend to be more prominent in environments proximal to 
terrigenous source areas (Elias and Young, 1998). Organisms that inhabit these environments are predominantly eurytopic. They tend to be less specialized, are capable of tolerating environmental fluctuations, and commonly employ opportunistic life-strategies that enable them to quickly colonize new environments when the conditions are appropriate.

In contrast, environments that are not frequently subjected to physical disturbances have a high degree of environmental stability. These environments are generally isolated from frequent episodes of increased turbidity and fluctuating salinity by either increased distance from terrigenous sources or increased water depth. These environments often contain a significant number of stenotopic organisms that are less tolerant of fluctuating environmental parameters (Levinton, 1970). The distribution of biofacies along the environmental gradient produced by MST segregates eurytopic Biofacies 1, 2, and 5, and stenotopic Biofacies 3 and 4. The ends of the gradient are occupied by eurytopic Biofacies that are tolerant of environmental instability, whereas the middle of the gradient is occupied by stenotopic Biofacies (3 and 4) that are less tolerant of environmental instability. Therefore, the distribution of stenotopic and eurytopic biofacies along the gradient is related to high environmental stability in the middle of the gradient and low environmental stability toward the ends (Figure 2-7B).

The use of gradient analysis sheds some light on the particular conditions that contributed to environmental instability. When sample lithologies are plotted along the horizontal axis, most of the limestones sampled in this study are positioned along the left-hand side of the gradient and the right-hand side of the gradient is composed almost exclusively of shale samples. The stability gradient can now be divided into two recognizable sub-gradients: a carbonatedominated gradient on the left-hand side and a clastic-dominated gradient on the right-hand side (Figure 2-7B). The two sub-gradients converge in the middle, regardless of whether the samples 
are associated with the clastic- or carbonate-dominated sub-gradients, because the samples in the middle of the gradient contain the stenotopic Biofacies 3 and 4 that required a high degree of environmental stability. Towards either end of the gradient, the stenotopic biofacies are displaced by eurytopic biofacies, but the transition to eurytopic biofacies varies between the carbonate- and clastic-dominated sub-gradients.

On the clastic-dominated sub-gradient, the majority of samples that contain stenotopic faunas are within the range of Biofacies 3. Biofacies 3 grades into Biofacies 2 which in turn, grades into Biofacies 1 (Figure 2-7B). The transition from stenohaline, epifaunal, suspensionfeeding brachiopods to euryhaline, epifaunal to semi-infaunal, grazing and deposit-feeding gastropods, to euryhaline infaunal bivalves represents a drastic change in the trophic (suspension- vs. deposit-feeders) and habitat (epifaunal vs. infaunal) preference of these assemblages. This may reflect a significant increase in turbidity. Non-molluscan taxa that show an increase toward the end of this gradient are the strongly eurytopic, the opportunistic brachiopod, Crurithyris, and the polycheate serpulid worms.

On the carbonate sub-gradient, samples transition from the stenotopic Biofacies 4 to the eurytopic Biofacies 5 (Figure 2-7B). As mentioned in the biofacies description, the transition from stenohaline, epifaunal, suspension-feeders to a euryhaline, epifaunal, suspension-feeder suggests that conditions varied along the carbonate-dominated gradient, but most significantly in regards to salinity. If there had been a significant increase in turbidity, then the trophic and habitat preferences should vary between biofacies in a similar manner as on the clasticdominated side of the gradient.

Variations in the degree of environmental stability in the Glenshaw Formation are not surprising given the nature of these marine zones. In Somerset Co., PA the Glenshaw Formation 
reaches a thickness of about $125 \mathrm{~m}$ (Edmunds at al., 1999). However, the total thickness of the four marine zones measured in this study in Somerset and adjacent Fayette counties totals only $15.9 \mathrm{~m}$, accounting for less than $13 \%$ of the total thickness. Thus, these zones represent shortlived episodes of marine influence in a basin that was otherwise predominantly nonmarine. Increased short-term environmental stability was periodically established during the onset of marine conditions that temporarily displaced unstable environments that persisted on the nonmarine alluvial landscape. The seafloor was available for colonization by stenotopic organisms for only a short period of time until increasing environmental stress reduced the degree of environmental stability.

Previous research in the Glenshaw Formation also concluded that the degree of environmental stability was a major factor controlling the distribution of fossil assemblages (Donahue and Rollins, 1974; Rollins and Donahue, 1975; Rollins et al., 1979). Although these studies did contribute to the understanding of fossil distributions in Glenshaw marine zones, generic diversity was used as a strict indicator of environmental stability based on the timestability concept of Sanders (1968), which is now thought to be an oversimplification of diversity patterns. The degree of environmental stability was also cited by Springer and Bambach (1985) who performed gradient analysis on benthic faunas in the Martinsburg Formation (Ordovician) in southwestern Virginia. They used gradient analysis to illustrate how marine benthic organisms were distributed along a nearshore to offshore gradient. They concluded that nearshore settings with a low degree of environmental stability are often predominantly inhabited by eurytopic taxa tolerant of fluctuating conditions, whereas offshore settings with a high degree of environmental stability are predominantly inhabited by stenotopic taxa that prefer a more stable set of environmental conditions. 


\subsubsection{REGIONAL FACTORS AFFECTING ENVIRONMENTAL STABILITY}

\subsubsection{Rapid Transgression}

The degree of environmental stability can vary significantly within a single transgressiveregressive sea level cycle (Donahue and Rollins, 1974; Rollins and Donahue, 1975; Rollins et al., 1979). During the initial transgressive stages, environmental conditions tend to fluctuate as open marine conditions initially mix with and later replace nearshore habitats influenced by terrigenous sources. Faunas established during this phase typically have a high percentage of opportunistic or eurytopic taxa that can tolerate these fluctuations and rapidly colonize new environments. However, the scarcity of eurytopic biofacies at the base of Glenshaw marine zones suggest that marine conditions rapidly overwhelmed the influence of terrigenous sources in nearshore habitats leading to increased environmental stability.

Glacial ablation proceeded more rapidly than accretion producing asymmetric relative sea-level cycles in the Glenshaw Formation with a rapid transgressive phase and a slow regressive phase (Nadon and Kelley, 2004). Rapid transgression of marine waters had a stabilizing effect on environments in the Glenshaw Formation by quickly establishing marine conditions in most parts of the basin. Not only would the influence of terrigenous sources have been reduced during transgression as sediments become trapped in coastal estuaries (Brett, 1998), but progressive deepening would have isolated the benthic habitat from environmental fluctuations by increased depth or distance from the shoreline. This is illustrated by the occurrence of stenotopic, suspension-feeding faunas at the base of 16 of the 20 localities sampled in the Glenshaw Formation. These initial stenotopic faunas are located along the middle part of the Glenshaw gradient and are dominated by either opportunistic chonetid brachiopods in 
Biofacies 3 or by crinoids in Biofacies 4 (Figure 2-7).

The presence of either Biofacies 3 or 4 is most likely related to whether advancing marine environments were influenced by local terrigenous sources throughout the transgressive phase. Glenshaw marine zones that begin with Biofacies 3 are located on the clastic-dominated side of the environmental gradient (e.g. BCY2A, CAMH1, NAY1, ANMO1, BELL2, BELN1, FAIR1A, and GRR5A and 5B) and were subjected to low amounts of turbidity and/of freshwater influx during much of the transgressive phase. Glenshaw marine zones that begin with Biofacies 4 are located on the carbonate-dominated side of the gradient (e.g. BCP1, UBCH2, PCY1, NAP1, AMA1, AMP1A, and CONC) and were deposited under fairly clear-water, normal marine conditions during the transgressive phase. Brachiopods that compose Biofacies 3 would have been more tolerant to increased turbidity and variations in salinity associated with these sources than the stenotopic suspension-feeding corals and echinoderms in Biofacies 4 (Brett, 1998).

\subsubsection{Extent of Marine Transgressions}

Each of the four major marine zones examined in the Glenshaw Formation were deposited during successive transgressive-regressive episodes (Boardman et al., 1984). However, the extent and/or duration of the four marine transgressions was variable (Busch, 1984; Busch and West, 1987). Figure 1-8 shows the relative extent of the four transgressions. The two least extensive transgressions, Upper Brush Creek (Pine Creek) and Cambridge (Nadine) Members, are grouped together and compared to the more extensive transgressions in the Lower Brush Creek (Brush Creek) and Ames Members. However, only samples from the northern, eastern, and southern sampling regions where all four marine zones could be equally sampled were 
considered for this comparison. In addition, percentages are also used because the total number of samples for the more extensive transgressions (18) is greater than the number of samples (16) for the less extensive transgressions.

The combined gradients of the Upper Brush Creek (Pine Creek) and Cambridge (Nadine) show relatively little variation in biofacies distribution (Figure 2-9A). Of the 16 samples along the gradient, only three, or less than $20 \%$, do not fall within the stenotopic Biofacies 3 and 4 . Of those three, two were collected from the Upper Brush Creek (Pine Creek) near Kittanning, PA and were influenced by very limited oxygen availability (see Northern samples gradient below). The lack of biofacies variability in these marine units is attributed to the limited extent of these transgressions. The transgressive phase would have been shorter than the more extensive transgressions as less marine water was available to fill the basin. Faunas established during transgression would have the least amount of surface area to inhabit and the most limited variation in water depth. Both of these factors would reduce faunal variation during these marine events by minimizing the variation of benthic habitats. Once the influx of marine waters ceased, regression would proceed in a series of relatively shallow-water environments when compared to the more extensive transgressions. Environmental instability would have been higher and may have precluded the establishment of eurytopic biofacies in much the same way that regressive biofacies are often masked near terrigenous sources (e.g., Bennington, 2002).

The combined gradients of the more extensive Lower Brush Creek (Brush Creek) and Ames transgressions shows considerable biofacies variation (Figure 2-9B). Of the 18 samples along the gradient, nine are assigned to the stenotopic Biofacies 3 and 4, and nine samples, or $50 \%$, are assigned to the eurytopic Biofacies 1,2 , and 5 . The variety of biofacies in these marine units is attributed to the greater extent of these transgressions. In fact, faunal variation is often 
cited as an important criterion in selecting the Ames for paleontological and paleoecological studies in the Appalachian Basin (e.g., Donahue and Rollins, 1974; Brezinski, 1983). In the more extensive marine events, the transgressive phase would have been relatively long as a greater volume of marine water entered the basin. Faunas established during transgression would have had more surface area to inhabit and greater variation in water depth. Both of these factors would increase faunal variation during these marine events by maximizing the variety of conditions within the benthic habitat. Once the influx of marine waters ceased, the stillstand and regressive phases would have progressed in a series of relatively deep-water environments when compared to the less extensive transgressions. Similar to the transgressive phase, available surface area and depth variation would be greater, maximizing faunal variation. A greater proportion of the benthic habitat would be buffered from environmental instability by increased depth and/or distance from the shoreline. As regression slowly progresses, environmental instability would gradually increase favoring the establishment of eurytopic biofacies until conditions were too stressful for benthic colonization.

The relationship between the extent of transgression and biofacies variation may be related in part to the increased surface area available for colonization by benthic invertebrates in the more extensive transgressions, and the reduced surface area in the less extensive transgressions. However, the relationship between the extent of transgression and the stratigraphic distribution of biofacies may also be related to the preservation potential of biofacies sequences. The more extensive transgressions would provide greater accommodation space for the accumulation and preservation of a complete sequence of biofacies. In contrast, the less extensive transgressions would provide less accommodation space to preserve a complete sequence of biofacies. This is especially true with biofacies at or near the top of a given 
sequence. The basal assemblages represent the offshore portion of a sea-level cycle, and the upper assemblages represent the nearshore portion of the sea-level cycle. The upper (nearshore) assemblages would inherently be more prone to erosion either during the final stages of the current sea-level cycle or the post-depositional phase. This would reduce the number of samples that contain nearshore biofacies when compared to the number of samples that contain offshore biofacies.

\subsubsection{LOCALIZED FACTORS AFFECTING BIOFACIES VARIATION}

Subsidence rates in the Appalachian basin fluctuated dramatically during the Pennsylvanian, the lowest rates coinciding with the deposition of the Conemaugh Group (Nadon and Kelley, 2004). Low subsidence rates, i.e., low accommodation space, variations in the duration and extent of each marine incursion, and the amount of exposure and fluvial incision during lowstand, have made the application of high-resolution sequence stratigraphic techniques unusually difficult in the Appalachian basin (Nadon and Kelley, 2004). This difficulty extends to the correlation of marine biofacies in the Appalachian basin established after transgression. Variations in total accommodation space, distance from the Midcontinent Sea (source of marine influence), and the activity of localized terrigenous sources tended to compartmentalize marine environments established in the Glenshaw Formation, especially during stillstand and slow regression. For this reason, samples along the Glenshaw samples gradient will be divided into groups based on their geographic location. These sample groups will be used to construct separate gradients to determine the influence of localized factors responsible for biofacies variation. 


\subsubsection{Southern Samples Gradient}

This gradient contains samples collected from the four major Glenshaw marine zones in the southernmost portion of the study area in Boyd and Lawrence counties, Kentucky, and Wayne County, West Virginia (Figure 2-10A). Of the twelve samples along this gradient, only three samples, LBCH2, LBCH4, and AMH1, are assigned to eurytopic biofacies. This most likely reflects close proximity of this part of the Appalachian Basin to the source of marine influence in the Midcontinent Basin. Marine waters in this part of the basin would have been more likely to have circulated with marine waters from the larger Midcontinent Sea to the southwest and contributed to the predominance of normal marine conditions in this area.

Two of these eurytopic samples, LBCH2 and AMH1, occur at the base of their respective marine zones in this area. This is a rather unusual occurrence in this study where 16 of the 20 basal samples collected elsewhere in the basin contain stenotopic Biofacies 3 or 4, attributed to rapid transgression. The development of eurytopic biofacies at the base of a transgressiveregressive cycle is often associated with a slow rate of transgression (Rollins and Donahue, 1975). Advancing marine waters would slowly mix with freshwater from terrigenous sources and produce brackish-water environments and the establishment of eurytopic faunas prior to the arrival of normal marine conditions. A slow rate of transgression may be due to decreased subsidence rates in this portion of the Appalachian Basin. It has been previously demonstrated that minor structural features in this region associated with the Pittsburgh-ParkersburgHuntington Syncline were active during deposition of the Glenshaw Formation (Merrill, 1988). However, prior facies analysis of the Ames Member in this area indicates that subsidence rates in this area were lower when compared to the Ames Member in the northeast (Merrill, 1993). As subsidence rates vary within a basin undergoing marine inundation, the rate of transgression in 
areas subject to faster subsidence will appear more rapid, whereas rates of transgression in areas subject to slower subsidence rates will be lower (Rollins and Donahue, 1975). Lower subsidence rates could also contribute to the presence of a topographic high in the seaway connecting the Midcontinent and Appalachian basins that restricted the migration of nektonic cephalopods from the Midcontinent Sea (Boardman et al., 1984).

The occurrence of two eurytopic samples, LBCH2 and LBCH4, in the Lower Brush Creek may be related to the influence of an active terrigenous source in this area. Of the four major marine zones in this area, only the Lower Brush Creek cyclothem contains evidence of deltaic influence, which was not as widespread in the Glenshaw Formation as previously thought (Martino, 2004). The influence of terrigenous sources, particularly freshwater influx, is evident in the marine portion of the Lower Brush Creek cyclothem. The Lower Brush Creek marine zone contains the only dark-gray shales sampled in this area. The dark color of these shales is most likely the result of concentrated organic matter in the sediment, the result of increased freshwater influx (see Biofacies 1 description above). The abundant infaunal bivalves and serpulid worm tubes would have been tolerant of the most severe environmental stress associated with terrigenous influx.

\subsubsection{Northern Samples Gradient}

This gradient contains samples collected from the four major Glenshaw marine zones in the northernmost portion of the study area in Allegheny and Armstrong counties, Pennsylvania (Figure 2-10B). Of the nine samples along this gradient, four (45\%) are assigned to the eurytopic Biofacies 2 and 5, and five are assigned to the stenotopic Biofacies 3 and 4. Marine zones sampled in the northern area are the farthest from the source of marine waters to the 
southwest. Circulation with normal marine waters from the Midcontinent Sea would have been less frequent in this area and most likely contributes to a higher proportion of eurytopic biofacies.

The results of MST in the northern region positioned samples from the Brush Creek, Nadine and Ames members along one side of the gradient representing an increase in environmental stress (Figure 2-10B). On the Glenshaw gradient, samples from these three zones were positioned along the carbonate-dominated sub-gradient suggesting that environmental stress was the result of increased freshwater influx with no significant increase in turbidity (Figure 2-7B). The transition from Biofacies 4, consisting of stenotopic, suspension-feeders at the base of the Nadine and Ames members to Biofacies 5 consisting of eurytopic suspensionfeeders supports this hypothesis (see gradient interpretation above). In addition, the predominance of limestones and the relatively thin vertical extent of the fossiliferous intervals in these marine zones also suggests that clastic influx was low during the deposition of marine zones in the northern samples area.

The results of MST positioned samples taken from the Pine Creek marine zone on the opposite end of the northern samples gradient (Figure 2-10B). On the Glenshaw gradient, one sample is assigned to Biofacies 3, and the other two are assigned to Biofacies 2 along the clasticdominated sub-gradient (Figure 2-7B). However, lithologic and paleontologic evidence suggests that assignment to the clastic-dominated sub-gradient is not the result of increased turbidity but, instead, limited oxygen availability during much of the marine portion of the Pine Creek sealevel cycle. Samples of the Pine Creek were taken from fissile, black shales or non-fissile, black calcareous shales. The basal sample, PCP1, contains a diminutive fauna composed primarily of high-spired, microgastropods that are less than $5 \mathrm{~mm}$ in length and account for over $75 \%$ of the 
fossils. Similar faunal assemblages have been reported from Marion and Harrison counties in north-Central West Virginia and were attributed to limited oxygen availability (Lebold and Kammer, this volume, submitted). Sample PCP2, taken just above PCP1, is composed almost exclusively of small, less than $1 \mathrm{~cm}$ at their greatest width, chonetid brachiopods. These opportunists rapidly colonized the seafloor in response to an increase in oxygen availability. The uppermost sample, PCP3, contains a diverse assemblage of gastropods, corals, crinoids, and a few infaunal bivalves. The high-spired gastropods in this sample are much larger than those from sample PCP1, often approaching $3 \mathrm{~cm}$ in length. The vertical succession of faunas at this Pine Creek outcrop suggests that there was an overall increase in oxygen availability during the transgressive-regressive cycle. The lowest oxygen levels most likely coincided with the transgressive and stillstand phases of the Pine Creek Sea represented in sample PCP1. Widespread anoxia and low-oxygen bottom waters are typically associated with transgression (Brett, 1998). Low oxygen conditions in the stillstand phase were likely the result of estuarine circulation caused by freshwater influx. Less-dense, well-oxygenated fresh water collected on the surface and restricted vertical circulation of denser, marine bottom waters (Heckel, 1991). The breakdown of low oxygen conditions probably occurred during early regression when the input of sediments and/or sea level fall that accompanies regression causes a breakdown of the stratified water column (Wignall, 1991). However, the presence of limestones and light-colored shales that contain abundant stenotopic and eurytopic faunas in the Pine Creek marine zone to the southwest (Busch, 1984) suggests that low-oxygen conditions were very localized, possibly near a terrigenous source that delivered freshwater to the basin.

\subsubsection{Eastern Samples Gradient}


This gradient contains samples collected from the four major Glenshaw marine zones in the easternmost portion of the study area in Fayette and Somerset cos., Pennsylvania combined with Ames Member transect samples collected in Barbour, Harrison, Marion, and Monongalia Cos., West Virginia (Figure 2-10C). There is considerable faunal variability in these samples with all five biofacies represented. Stenotopic Biofacies 3 and 4 occur within 17 samples, whereas 13 samples are assigned to the eurytopic Biofacies 1, 2, and 5 . Biofacies variation in the eastern region is related to high subsidence rates combined with close proximity to terrigenous sources.

The eastern portion of the Appalachian Basin was proximal to the recently-uplifted Appalachian Highlands. Several studies including Arkle (1974), Al-Qayim (1983), Merrill (1988), and Joeckel (1995) have shown that net subsidence rates during Conemaugh times were higher in this part of the basin. Deposition took place in a rapidly-subsiding foredeep trough near terrigenous sources to the southeast (Joeckel, 1995). Rapid transgression led to the establishment of either the stenotopic Biofacies 3 or 4 in a normal marine environment with low to moderate turbidity. As transgression slowed and eventually ceased, eastern terrigenous sources became increasingly active. Periodic freshwater influx and turbidity associated with these sources decreased environmental stability and led to the establishment of eurytopic biofacies during regression. The repetition of this sequence in the Ames marine zone at the ANMO, FAIR, and GRR suggests that two cycles of sea level change are preserved.

Due to the greater availability of Ames exposures when compared to the other three marine zones in the Glenshaw Formation, the number of samples (36) in the Ames Member was significantly greater than the combined sample total (24) of the other marine zones in this study. To determine if the higher number of samples from the Ames Member was responsible for the 
increased variation observed along the gradient, a separate gradient was constructed using randomized Ames Member sample sets (Figure 2-11). The randomized sets each consisted of ten samples, which corresponds to the number of Ames Member samples collected in the field to account for faunal variability in the geographic areas where all of the other marine zones could be sampled. Ten gradients were constructed each containing 10 randomly generated sets of Ames Member samples. Each sample was assigned a random number generated in Microsoft

Excel. The samples were then sorted according to the value of each random number and the first 10 samples were selected. The results of MST were then used to define the order of samples along each gradient. These gradients were placed on top of each other to determine if the variability of each set of 10 samples could produce the same biofacies variation as shown in all 36 Ames Member samples. Due to an especially high occurrence of the BRACH megaguild in the Ames Member, the data were divided into two sets, one containing samples with a greater than $60 \%$ occurrence of the BRACH megaguild and the other set containing the remaining samples with less than a $60 \%$ occurrence of the BRACH megaguild. Three samples from the first set were combined with seven samples from the second set totaling 10 samples in each randomized set. The results indicate that similar biofacies variability could be illustrated with only 10 randomly selected samples as in all 36 Ames Member samples. Therefore, the greater number of Ames Member samples does not significantly increase biofacies variability.

\subsubsection{Western Samples Gradient}

Due to uncertainty surrounding the identification of the four major Glenshaw marine zones in Athens County, Ohio, only the uppermost marine zone, the Ames Member, could be confidently identified and sampled (Nadon, pers. comm., 2003) in this area. These samples were 
combined with Ames Member transect samples collected from Guernsey, Noble, and Washington counties, Ohio (Figure 2-10D). Of the eight samples assigned to this gradient, six are assigned to the stenotopic Biofacies 3 or 4, and two are assigned to the eurytopic Biofacies 5 .

In a recent study, Nadon and Kelley (2004) concluded that multiple transgressiveregressive events, or sequences, were responsible for the pattern of facies distribution during the deposition of the Ames Member in Athens, Ohio. Within the Ames interval, three sequence boundaries were identified by Nadon and Kelley (2004) at the top of a blocky mudstone below the Ames interval, at the top of a sandstone below the Ames Limestone, and at the top of the Ames Limestone. The fossiliferous units sampled in the present study were located above the second sequence boundary. The other two sequence boundaries were not associated with invertebrate fossils.

The western portion of the Appalachian basin was situated on the gently sloping Cincinnati Arch. Deposition took place in a passive-margin setting away from increased subsidence rates and terrigenous influx associated with the recently-uplifted Appalachian Highlands to the east (Joeckel, 1995). Rapid transgression led to the establishment of either Biofacies 3 or 4 in a normal marine environment with low turbidity. During regression, the appearance of Biofacies 5 suggests a gradual reduction in environmental stability related to fluctuating salinities within the Ames Member.

\subsubsection{CONCLUSIONS}

The results of Q-mode cluster analysis and minimum-spanning tree (MST) were used to position samples of the Glenshaw Formation in the Appalachian basin along an environmental continuum based on the proportional abundance of fossils. Indirect gradient analysis permitted 
the comparison of the position of biofacies relative to one another along an environmental continuum. Biofacies are designated 1-5 and correspond to the distribution of taxa within five megaguilds: INBIV (INDEPBIV, INSUSBIV and SPIROR), GAST/SCA (BELLERO, EUPHEM, LOXONEM, PLEURO, SCAPHO), BRACHS (CHONET, PEDUNC, PRODUCT, and STROPHO), STENO (BRYO, CEPHALO, CORAL, CRINOID, EPIBIV, and TRILO), and CRURI, which contains the pedunculate brachiopod Crurithyris. The use of gradient analysis to compare fossil assemblages provides a distinct advantage over previous studies that only identified and qualitatively described discrete biofacies in the Glenshaw Formation. Gradient analysis aids not only in the analysis of the faunal composition of a given biofacies, but all biofacies can be examined simultaneously across an environmental continuum. The position of each biofacies relative to others can be used to identify environmental factors that more often than not, continually change along gradients in nature. Approaching the distribution of assemblages as a continuum avoids potentially artificial subdivision of intergrading distributions, yet permits gaps or discontinuities in the gradient to emerge if they are present. Fossil associations identified during gradient analysis remain a part of the continuous spectrum of faunal distributions that have adapted to a particular set of environmental conditions represented by their position along a gradient.

The distribution of biofacies along the Glenshaw gradient is related to the degree of environmental stability related to the frequency of environmental fluctuations. Biofacies 3 and 4, located in the middle of the gradient, are composed of stenotopic suspension-feeding brachiopods, crinoids, bryozoans, and corals that require a high degree of environmental stability. Biofacies 1, 2, and 5, located on the ends of the gradient, are composed primarily of eurytopic molluscs and the eurytopic brachiopod Crurithyris that are tolerant a low degree of 
environmental stability.

Variations in the degree of environmental stability in the Glenshaw Formation are related to the pressure that physical processes exerted on marine environments established within the four marine zones. These marine zones represent short-lived episodes of marine influence in an otherwise predominantly nonmarine basin where the activity of terrigenous sources contributed to a low degree of environmental stability. The degree of environmental stability fluctuated during the establishment of marine faunas in the Glenshaw Formation due to the rate of relative sea level change, the relative extent of the four major marine incursions, variations in total accommodation space within the Appalachian basin, and geographic position relative to the source of marine influence from the Midcontinent Sea. Factors such as rapid transgression, a more extensive marine incursion, and close proximity to the source of marine influence increased environmental stability by buffering the benthic habitat from environmental fluctuations commonly associated with terrigenous sources. Whereas slow transgression, a less extensive marine incursion, and decreasing proximity to the marine source decreased environmental stability by increasing the influence of terrigenous sources on the benthic habitat. Greater accommodation space led to the deposition and/or preservation of a more complete sequence of biofacies. Whereas low total accommodation space hindered the deposition and/or preservation of eurytopic biofacies at the top of each marine zone. These results are consistent with previous ideas that the degree of environmental stability can be a primary factor controlling the distribution of benthic faunal assemblages in epicontinental seas.

This paper presents the first gradient analysis of the four major marine zones within the Glenshaw Formation on a broad geographic scale in the northern Appalachian basin. This work provides an example of how differences in the degree of environmental stability shaped the 
composition of faunal assemblages in the short-lived, shallow seas that existed during deposition of Glenshaw Formation. This research provides a basis for future paleoecological comparisons with fossil assemblages in predominantly nonmarine basins that were rapidly colonized during relatively short-lived episodes of marine influence. 
Table 2-1: Locations of sampled Glenshaw Formation outcrops.

Sample labels contain a code for the marine zone: LBC, BC = Lower

Brush Creek, Brush Creek; UBC, PC = Upper Brush Creek, Pine Creek;

CAM, NA = Cambridge, Nadine; and AM = Ames. Last letter indicates

a geographical reference point: $\mathrm{H}=$ Huntington, $\mathrm{WV} ; \mathrm{P}=$ Pittsburgh, $\mathrm{PA}$;

$\mathrm{W}=$ Wellersburg, PA; Y= Youghiogheny River Lake; and A = Athens, $\mathrm{OH}$.

\begin{tabular}{|c|c|c|}
\hline Sampled Member & County, State & UTM coordinates (zone 17) \\
\hline Ames (AMH) & Lawrence, KY & $4233480 \mathrm{~N}, 358880 \mathrm{E}$ \\
\hline Cambridge (CAMH) & Wayne, WV & $4235420 \mathrm{~N}, 366280 \mathrm{E}$ \\
\hline Lower Brush Creek (LBCH) & Lawrence, KY & $4247320 \mathrm{~N}, 351780 \mathrm{E}$ \\
\hline Upper Brush Creek (UBCH) & Lawrence, KY & $4218340 \mathrm{~N}, 357360 \mathrm{E}$ \\
\hline Ames (AMP) & Allegheny, PA & $4491800 \mathrm{~N}, 602540 \mathrm{E}$ \\
\hline Brush Creek (BCP) & Armstrong, PA & $4517960 \mathrm{~N}, 625420 \mathrm{E}$ \\
\hline Nadine (NAP) & Allegheny, PA & $4484520 \mathrm{~N}, 597140 \mathrm{E}$ \\
\hline Pine Creek (РCP) & Armstrong, PA & $4517740 \mathrm{~N}, 625460 \mathrm{E}$ \\
\hline Ames (AMW) & Somerset, PA & $4399280 \mathrm{~N}, 684440 \mathrm{E}$ \\
\hline Brush Creek (BCY) & Fayette, PA & $4402040 \mathrm{~N}, 637080 \mathrm{E}$ \\
\hline Nadine (NAY) & Somerset, PA & 4404920N, 638640E \\
\hline Pine Creek (PCY) & Somerset, PA & $4402220 \mathrm{~N}, 638100 \mathrm{E}$ \\
\hline Ames (AMA) & Athens, OH & $4352350 \mathrm{~N}, 405010 \mathrm{E}$ \\
\hline *Anmore (ANMO) & Harrison, WV & 4342200N, 560720E \\
\hline *Belle Valley (BELL) & Noble, $\mathrm{OH}$ & $4403400 \mathrm{~N}, 452580 \mathrm{E}$ \\
\hline *Belington (BELN) & Barbour, WV & $4320800 \mathrm{~N}, 592810 \mathrm{E}$ \\
\hline *New Concord (CONC) & Guernsey, OH & $4426080 \mathrm{~N}, 440800 \mathrm{E}$ \\
\hline *Fairmont (FAIR) & Marion, WV & 4371680N, 579220E \\
\hline *Greenbag Road (GRR) & Monongalia, WV & 4386100N, 591560E \\
\hline *Newport (NEW) & Washington, $\mathrm{OH}$ & $4360040 \mathrm{~N}, 478240 \mathrm{E}$ \\
\hline
\end{tabular}

*Ames Member exposures along a NW-SE transect across the northern Appalachian basin from Lebold and Kammer (this volume, submitted). 
Table 2-2: Guild Composition

Bryozoans (BRYO): bryozoan colony fragments

Cephalopods (CEPHALO): cephalopod fragments, possibly Metaceras and Tainoceras

Solitary rugose coral (CORAL): Stereostylus

Crinoids (CRINOID): isolated crinoid fragments

Loxonemitid gastropods (LOXONEM): Donaldina, Girtyspira, Meekospira, Pseudozygopleura, Strobeus, Stegocoelia, and Soleniscus

Pleurotomarid gastropods (PLEURO): Amphiscapha, Euomphalus, Glabrocingulum, Phymatopleura, Trepospira, Shansiella

Bellerophontid gastropod (EUPHEM): Euphemites

Bellerophontid gastropods (BELLERO): Bellerophon (Bellerophon), Knightites (Cymatospira), Knightites (Retispira), and Pharkidonotus

Infaunal Deposit feeding bivalves (INDEPBIV): Nuculopsis, Palaeoneilo, Paleyoldia, and Phestia

Infaunal Suspension feeding bivalves (INSUSBIV): Astartella, Edmondia, Permophorus, Promytilus, Prothyris, and Schizodus

Epifaunal bivalves (EPIBIV): Acanthopectin, Aviculopectin, Dunbarella, Fasciculaconcha, Paleolima, Pseudomontis, Septamyalina, and Streblochondria

Chonetid brachiopod (CHONET): Chonetinella and Neochonetes

Productid brachiopods (PRODUCT): Antiquatonia, Cancrinella, Hystriculina, Juresania, Kozlowskia, and Linoproductus

Pedunculate brachiopod (CRURI): Crurithyris

Pedunculate brachiopods (PEDUNC): Composita, Neospirifer, and Punctospirifer

Scaphopods (SCAPHO): Plagioglypta

Serpulid worm tubes (SPIROR): Spirorbis

Strophomenid brachiopods (STROPHO): Derbyia

Trilobites (TRILO): trilobite segments, possibly Ameura 
Table 2-3: Megaguild composition.

Megaguild (included guilds)

INBIV (INDEPBIV, INSUSBIV and SPIROR)

GAST/SCA (BELLERO, EUPHEM, LOXONEM, PLEURO, SCAPHO)

BRACHS (CHONET, PEDUNC, PRODUCT, and STROPHO)

STENO (BRYO, CEPHALO, CORAL, CRINOID, EPIBIV, and TRILO)

CRURI (CRURI) 
Table 2-4: Percent abundance of megaguilds in 60 samples collected from the Glenshaw Formation in the northern Appalachian basin. Samples are grouped according the megaguild that accounts for the greatest proportion of fossils collected from each sample. Samples BELL3, AMH1, and FAIR5 have a nearly equal proportion of fossils from two different megaguilds and were tentatively assigned along the border of two megaguild groups.

\begin{tabular}{|c|c|c|c|c|c|c|c|c|c|c|c|}
\hline & \multicolumn{5}{|c|}{ Megaguilds } & & \multicolumn{5}{|c|}{ Megaguilds } \\
\hline & CRURI & STENO & BRACH & GAST/SCA & INBIV & & CRURI & STENO & BRACH & GAST/SCA & INBIV \\
\hline AMW2B & 66.9 & 0.0 & 0.0 & 21.8 & 11.4 & CAMH1 & 0.0 & 12.8 & 74.1 & 10.2 & 3.0 \\
\hline AMA5 & 96.9 & 2.5 & 0.0 & 0.0 & 0.6 & NEW1 & 0.6 & 14.9 & 64.5 & 10.9 & 9.2 \\
\hline AMW2A & 96.0 & 3.7 & 0.0 & 0.3 & 0.0 & PCP2 & 0.0 & 5.6 & 89.2 & 4.6 & 0.7 \\
\hline AMP1B & 92.4 & 3.1 & 4.2 & 0.3 & 0.0 & FAIR3 & 0.0 & 4.7 & 88.8 & 4.4 & 2.2 \\
\hline AMA3 & 90.8 & 5.4 & 3.8 & 0.0 & 0.0 & BELL2 & 1.0 & 3.0 & 93.1 & 2.0 & 1.0 \\
\hline NAP3 & 59.2 & 35.6 & 4.2 & 0.0 & 1.0 & ANMO3 & 0.0 & 3.3 & 91.5 & 1.0 & 4.2 \\
\hline AMW1 & 38.7 & 22.0 & 28.0 & 8.7 & 2.7 & GRR9B & 0.0 & 0.6 & 98.5 & 0.0 & 0.9 \\
\hline \multirow[t]{2}{*}{ AMW3 } & 34.2 & 0.2 & 32.7 & 19.2 & 13.8 & GRR5B & 4.2 & 0.6 & 93.2 & 0.6 & 1.3 \\
\hline & & & & & & GRR9A & 5.2 & 0.0 & 94.8 & 0.0 & 0.0 \\
\hline AMP1A & 39.0 & 56.1 & 4.8 & 0.0 & 0.0 & GRR5A & 8.0 & 1.5 & 81.2 & 4.5 & 4.8 \\
\hline BELL5 & 14.5 & 71.3 & 12.2 & 1.4 & 0.7 & FAIR1A & 4.6 & 1.0 & 77.0 & 13.5 & 3.9 \\
\hline NAP1 & 9.7 & 86.1 & 1.6 & 0.5 & 2.1 & BELN1 & 0.0 & 1.6 & 77.9 & 17.9 & 2.6 \\
\hline PCY1 & 1.0 & 93.7 & 5.0 & 0.0 & 0.3 & AMH3 & 0.0 & 1.3 & 54.1 & 30.5 & 14.1 \\
\hline CAMH2 & 0.0 & 92.6 & 5.8 & 0.3 & 1.3 & BCY2A & 0.0 & 11.7 & 41.4 & 29.8 & 17.2 \\
\hline BCP1 & 2.0 & 84.3 & 5.0 & 2.7 & 6.0 & ANMO1 & 0.0 & 0.0 & 55.6 & 40.1 & 4.3 \\
\hline PCY2 & 0.0 & 86.7 & 2.4 & 7.5 & 3.5 & & & & & & \\
\hline NAY2A & 0.3 & 79.3 & 3.0 & 12.3 & 5.0 & FAIR2 & 0.0 & 0.3 & 37.5 & 61.2 & 1.0 \\
\hline BCY3 & 0.0 & 82.4 & 3.6 & 13.7 & 0.3 & ANMO2 & 0.0 & 0.0 & 19.9 & 75.8 & 4.3 \\
\hline ВСР3 & 5.8 & 59.4 & 0.3 & 28.4 & 6.1 & FAIR1B & 0.0 & 0.0 & 8.2 & 79.1 & 12.7 \\
\hline AMA1 & 0.0 & 93.1 & 6.9 & 0.0 & 0.0 & PCP1 & 0.0 & 0.0 & 0.0 & 89.8 & 10.2 \\
\hline NAY2B & 0.0 & 86.7 & 11.7 & 1.3 & 0.3 & PCP3 & 21.9 & 17.6 & 2.7 & 52.5 & 5.3 \\
\hline САМНЗА & 0.0 & 71.9 & 18.3 & 4.0 & 5.8 & ANMO4 & 0.0 & 0.3 & 0.3 & 65.4 & 33.9 \\
\hline CONC & 0.7 & 75.3 & 22.7 & 1.3 & 0.0 & BELN2 & 0.0 & 0.0 & 0.0 & 61.7 & 38.3 \\
\hline AMH2 & 0.0 & 51.6 & 23.9 & 16.0 & 8.5 & & & & & & \\
\hline PCY3 & 0.0 & 46.3 & 29.0 & 11.7 & 13.0 & AMH1 & 0.0 & 3.0 & 37.1 & 27.2 & 32.8 \\
\hline LBCH3 & 0.0 & 53.3 & 36.5 & 8.2 & 2.0 & BCY2B & 0.0 & 23.9 & 0.0 & 29.8 & 46.2 \\
\hline UBCH2 & 0.0 & 58.4 & 41.6 & 0.0 & 0.0 & LBCH4 & 0.0 & 4.0 & 35.5 & 10.6 & 49.8 \\
\hline \multirow[t]{2}{*}{ BELL3 } & 0.9 & 48.3 & 49.2 & 1.5 & 0.0 & GRR6B & 8.6 & 0.3 & 0.3 & 27.9 & 63.0 \\
\hline & & & & & & LBCH2 & 0.0 & 0.6 & 0.0 & 14.8 & 84.5 \\
\hline AMH4 & 0.0 & 36.5 & 63.5 & 0.0 & 0.0 & FAIR4 & 23.2 & 0.7 & 0.0 & 8.5 & 67.6 \\
\hline NAY1 & 0.0 & 16.1 & 83.2 & 0.0 & 0.7 & GRR6A & 38.1 & 1.9 & 1.6 & 14.1 & 44.4 \\
\hline САМНЗВ & 0.0 & 9.0 & 85.7 & 5.0 & 0.3 & FAIR5 & 36.3 & 5.7 & 11.0 & 12.3 & 34.7 \\
\hline
\end{tabular}


Table 2-5: Summary of biofacies interpretation

\begin{tabular}{|c|c|c|c|c|}
\hline \multirow{2}{*}{ Biofacies } & $\begin{array}{c}\text { Degree of } \\
\text { environmental } \\
\text { stability }\end{array}$ & Salinity & Turbidity & \multirow{2}{*}{$\mathbf{O}_{2}$ availability } \\
\cline { 1 - 1 } $\mathbf{1}$ & High & Variable & High & \multirow{2}{*}{ Oxic/Dysoxic } \\
\cline { 1 - 1 } 2 & Low & Variable/Marine & Moderate & \multirow{2}{*}{ Oxic } \\
\hline 3 & High & Marine & Low & \\
\hline 5 & & Variable & & \\
\hline
\end{tabular}




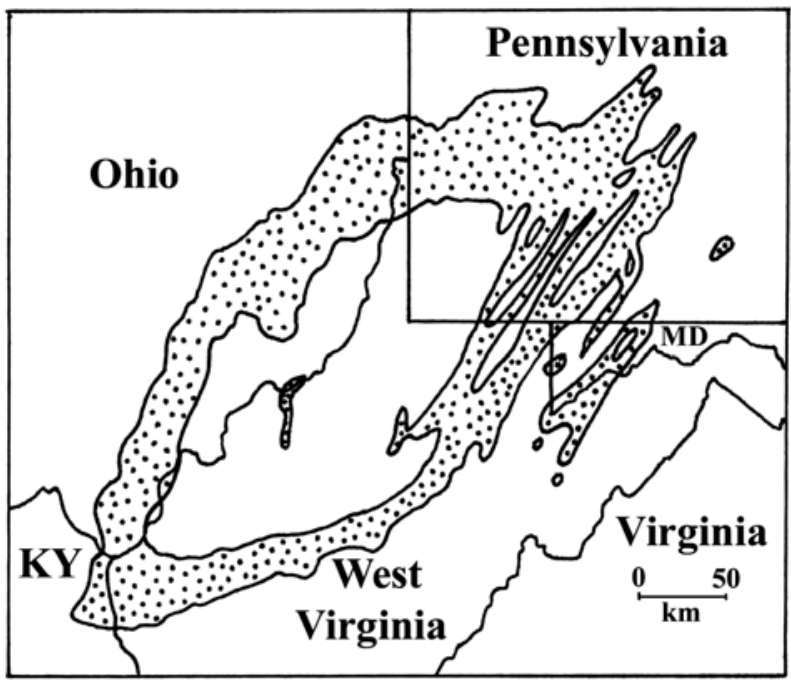

Figure 2-1. Distribution of the Conemaugh Group in the Appalachian basin. The Ames Member is located near the middle of the outcrop belt. Data compiled from state geologic maps. 


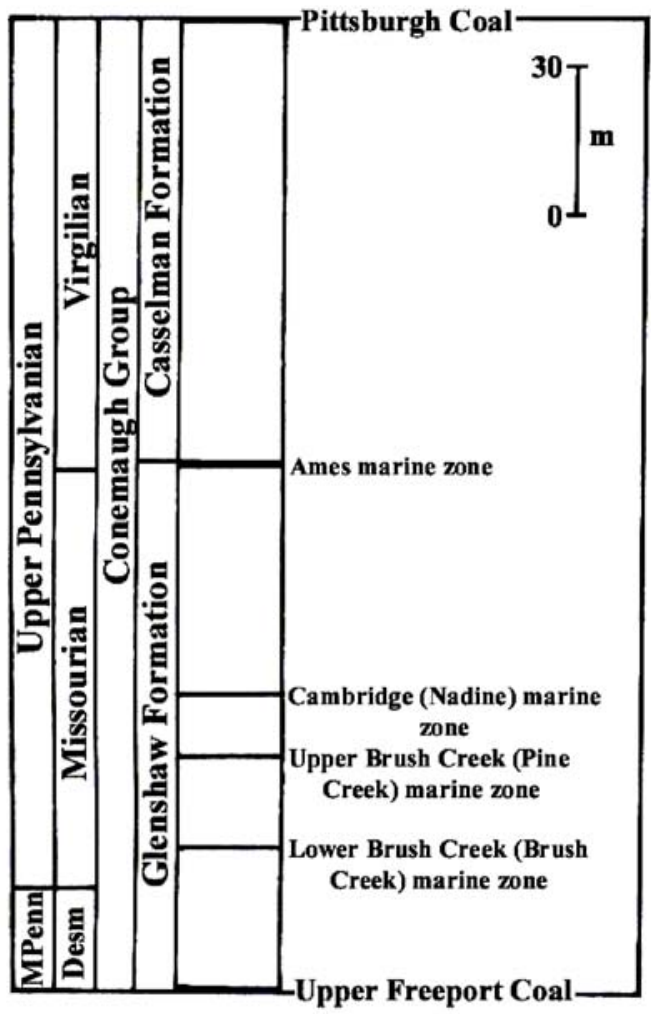

Figure 2-2. Generalized stratigraphic column of the Conemaugh Group with the position of the four major Glenshaw marine zones sampled in this study (modified from Edmunds et al., 1999). 


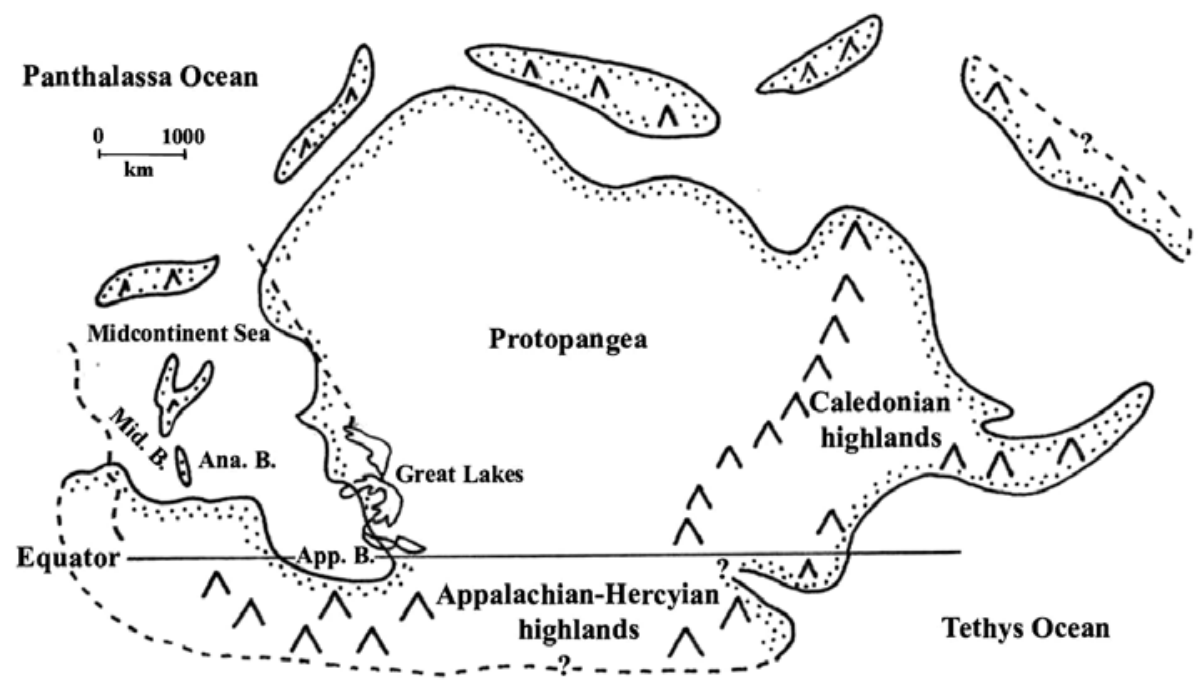

Figure 2-3. Interpreted paleogeography of the Euramerican part of Protopangea during the Late Pennsylvanian. The Great Lakes and portions of the north and south border of the present day United States (dashed lines) are included for reference. App. B = Appalachian basin; Mid. B. = Midland Basin; Ana. B. = Anadarko Basin (modified from Heckel, 1995). 


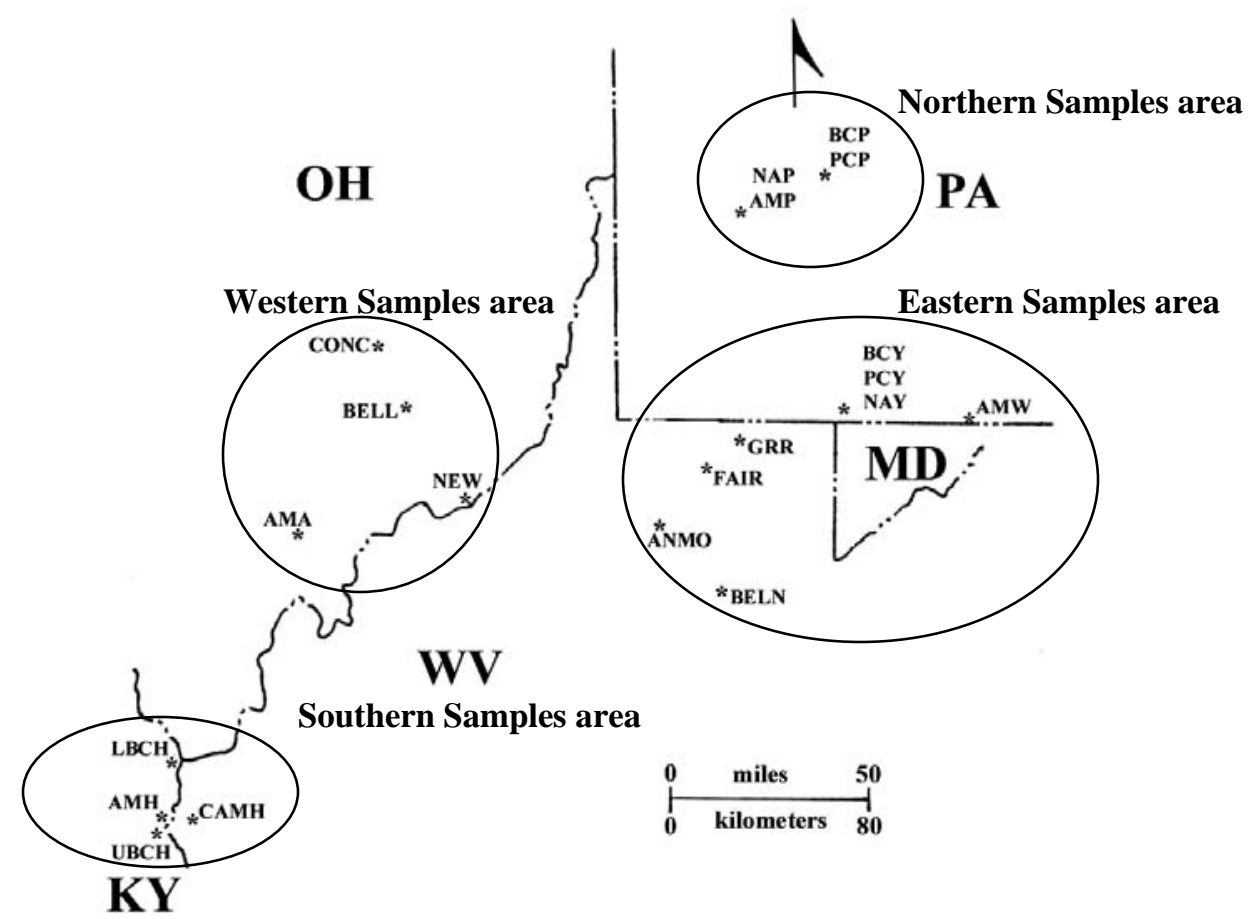

Figure 2-4. Map showing the locations of sampled Glenshaw marine zones within their respective geographic area in the northern Appalachian basin. Refer to Table 2-1 for outcrop abbreviations. 


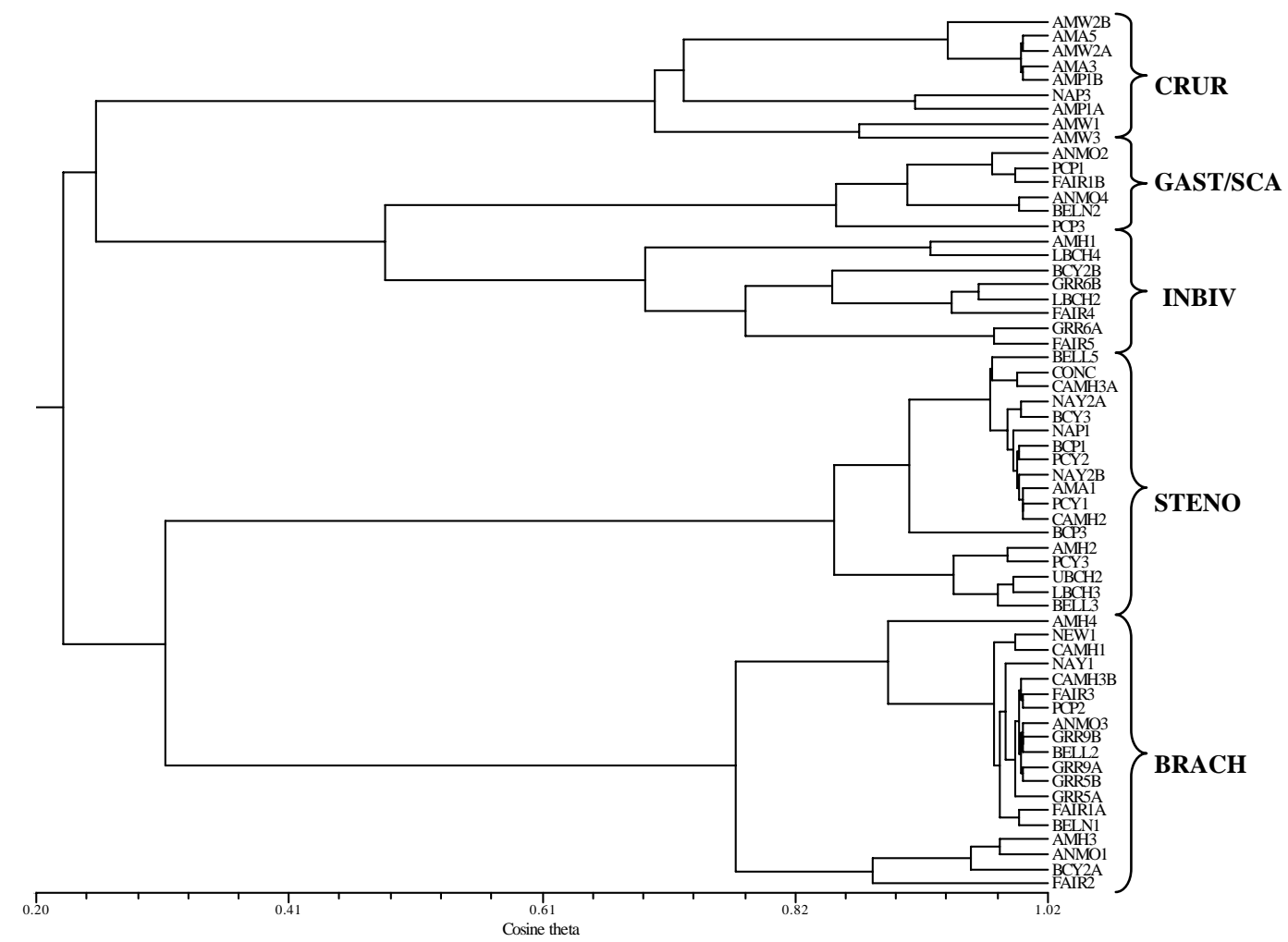

Figure 2-5. Q-mode cluster analysis of 60 Glenshaw Formation samples using the "unweighted pair-group method with arithmetic averaging" (UPGMA) and the cosine theta similarity coefficient, which is the appropriate similarity coefficient for Q-mode analysis (Joreskog et al., 1976). This analysis produced five clusters of sample groups based on megaguild abundance. 


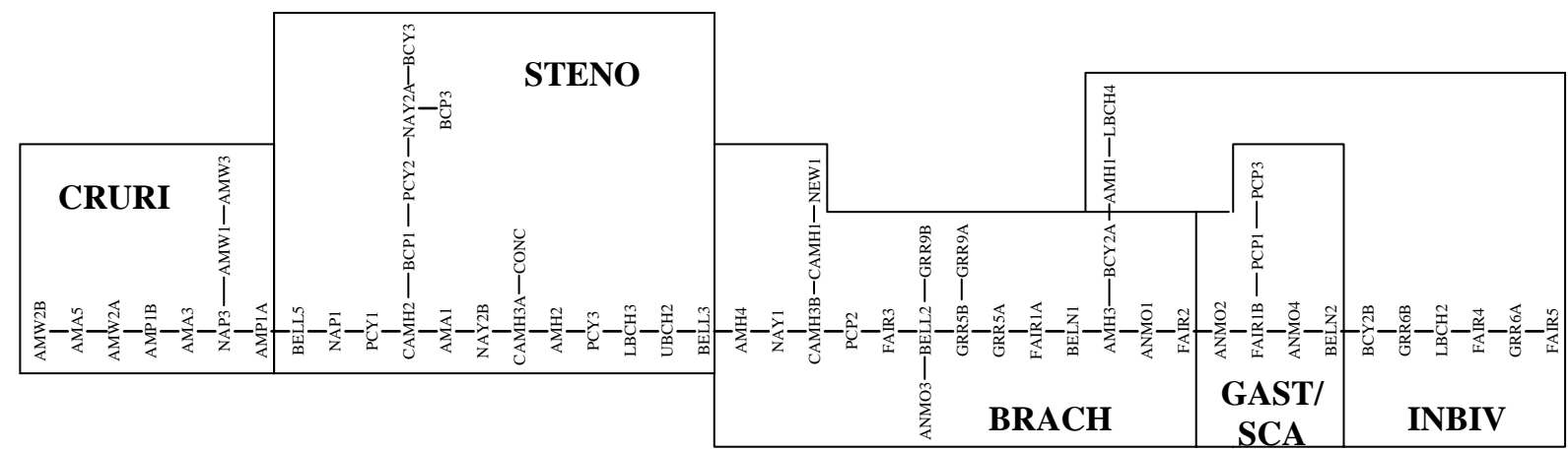

Figure 2-6. Minimum spanning tree (MST) of 60 Glenshaw samples. The five sample groups identified from Q-mode cluster analysis are superimposed on the tree to illustrate the sequential arrangement of sample groups. The purpose of this diagram was to order the samples in the data matrix and the distances between samples are not to scale. 

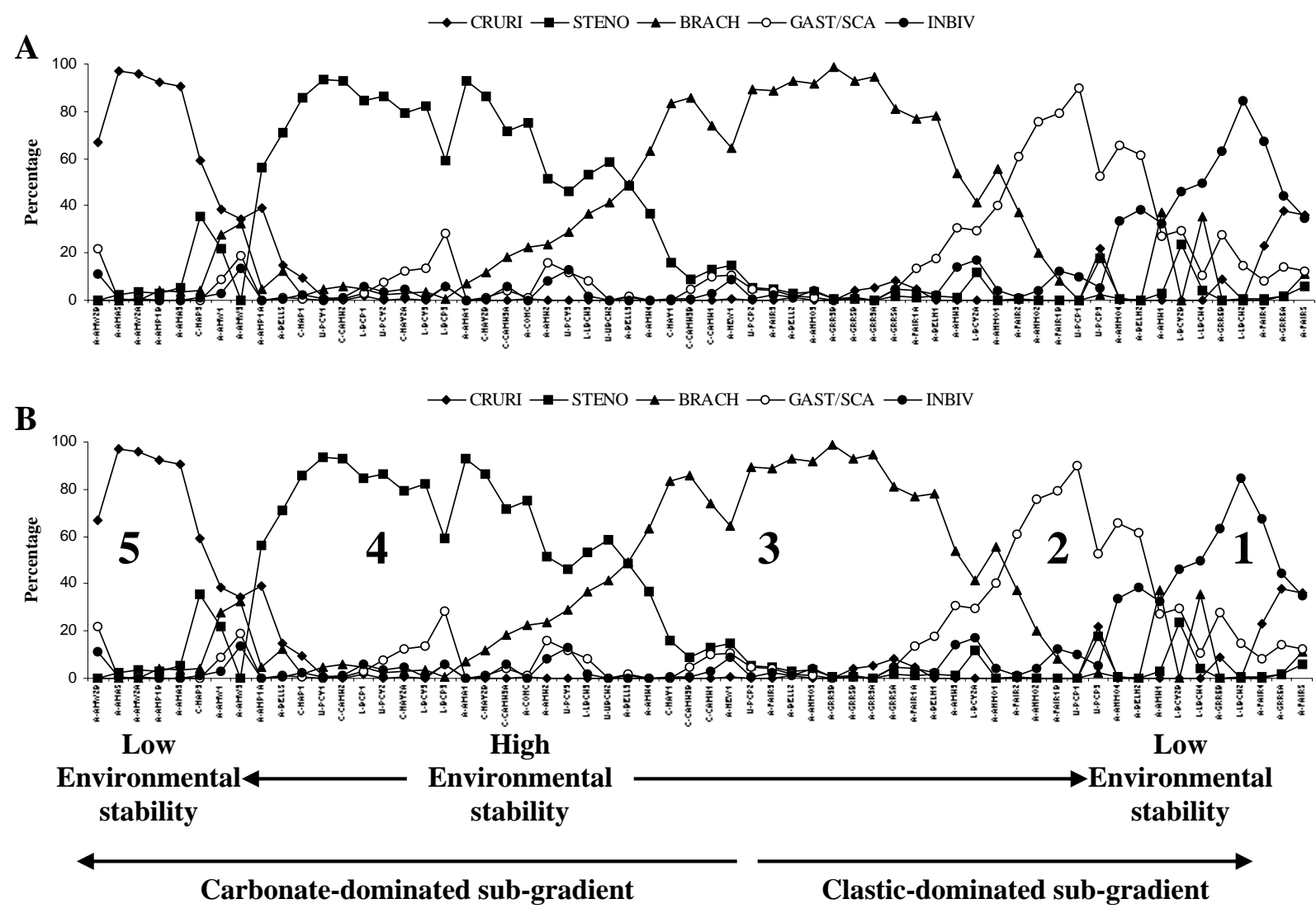

Figure 2-7. Gradient analysis of megaguild relative abundance.(A) Percent abundance of the five megaguilds designated as Biofacies 1-5. Samples have been arranged according to the results of Q-mode MST and cluster analysis and are labeled with a prefix identifying the marine zone to illustrate that the five biofacies are not stratigraphically defined: $\mathrm{L}=$ Lower Brush Creek (Brush Creek) U = Upper Brush Creek (Pine Creek); C = Cambridge (Nadine); $\mathrm{A}=$ Ames. (B) Line graph 2-7A fit with an interpreted gradient that represents changes in environmental stability from the middle of the chart to either end of the chart. The two sub-gradients represent the predominant lithology, carbonate or clastic, of samples. 


\begin{tabular}{|c|c|}
\hline $\begin{array}{c}\text { Glenshaw } \\
\text { marine zone }\end{array}$ & $\begin{array}{c}\text { Relative extent of trans- } \\
\text { gression, increasing to the right }\end{array}$ \\
\hline Ames Member \\
\hline $\begin{array}{c}\text { Cambridge (Nadine) } \\
\text { Member }\end{array}$ \\
\hline $\begin{array}{c}\text { Upper Brush Creek } \\
\text { (Pine Creek) Member }\end{array}$ \\
\hline $\begin{array}{c}\text { Lower Brush Creek } \\
\text { (Brush Creek) Member }\end{array}$ \\
\hline
\end{tabular}

Figure 2-8. Relative extent of marine transgression of the four Glenshaw marine zones sampled in this study.

Extent of transgression increases to the right (modified from Busch, 1984; Busch and West, 1987). 
A

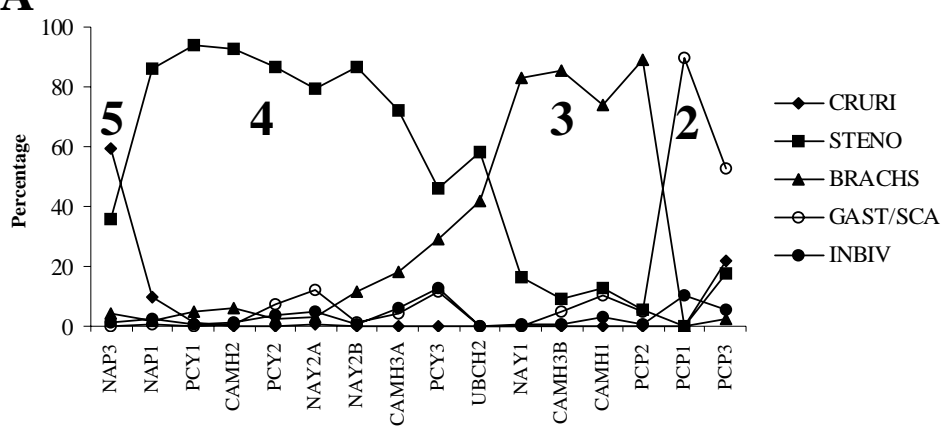

B

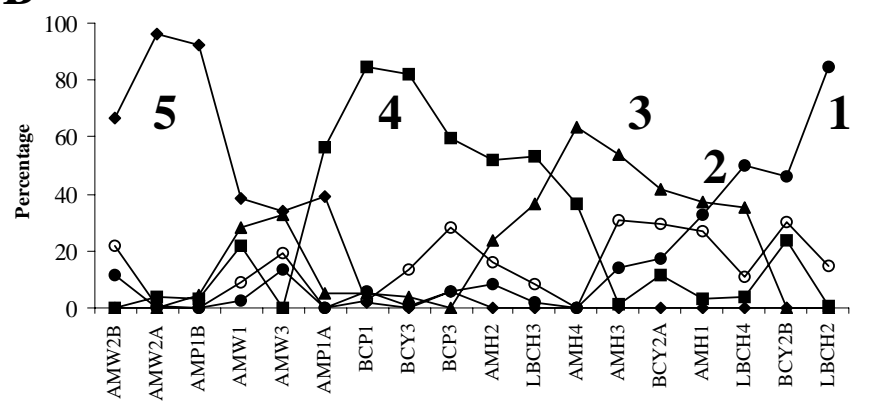

Figure 2-9. Gradient analysis of megaguild relative abundance.(A) Percent abundance of the five most abundant megaguilds plotted among samples taken from the less extensive marine transgressions, Upper Brush Creek (Pine Creek) and Cambridge (Nadine) Members. (B) Percent abundance of the five most abundant megaguilds plotted among samples taken from the more extensive marine transgressions, Lower Brush Creek (Brush Creek) and Ames Members. 

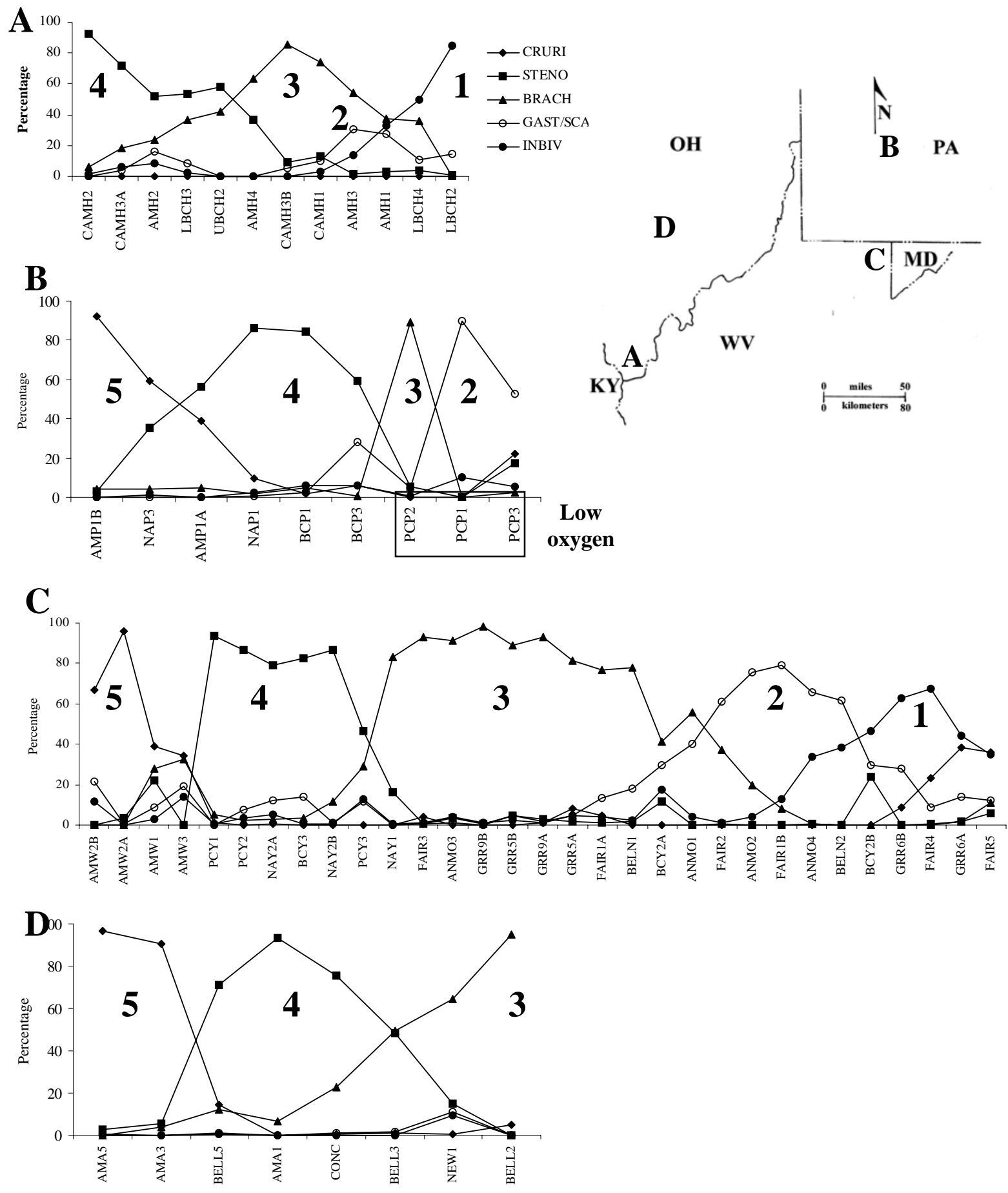

Figure 2-10. Gradient analysis of megaguild abundance. (A) Southern samples gradient. (B) Northern samples gradient. PCP samples are outlined to indicate low-oxygen conditions.(C) Eastern samples gradient. (D) Western samples gradient. Inset map shows approximate position of sample areas. 


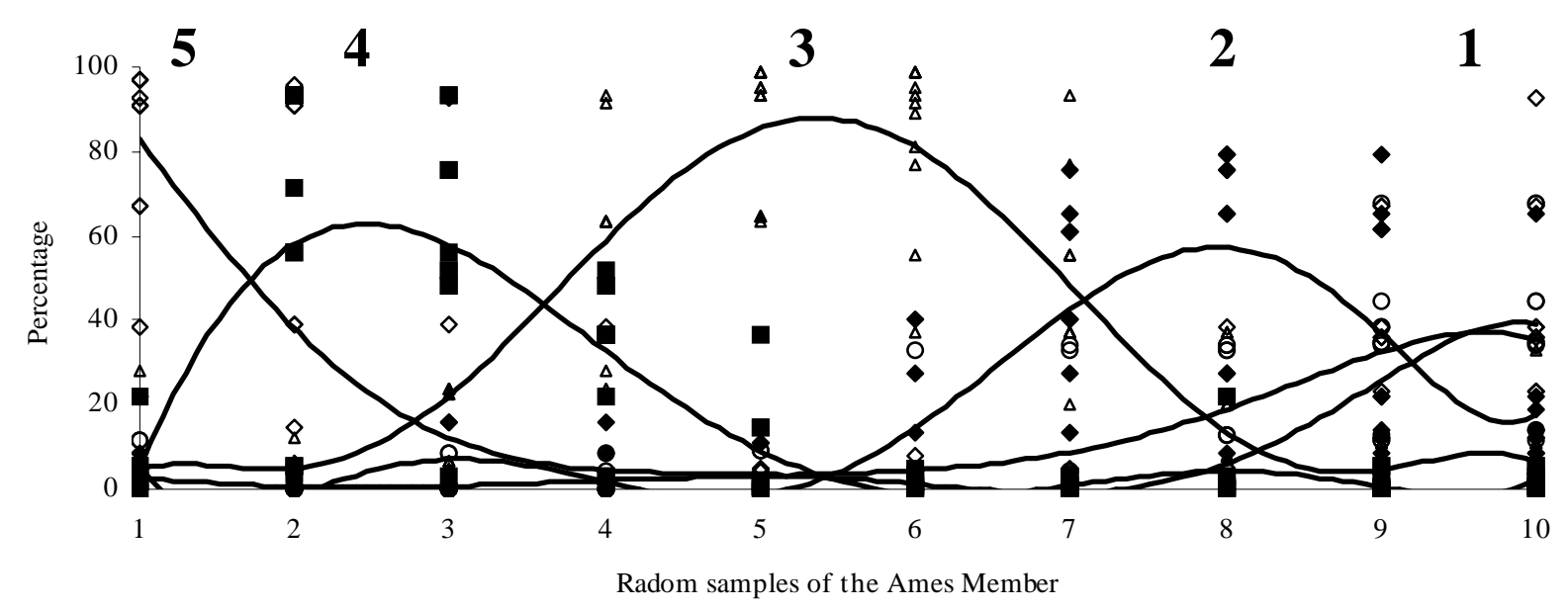

Figure 2-11. Line graph of Ames Member samples illustrating that maximum faunal variation can be represented by as few as 10 samples. Randomized samples were selected in order to determine if the greater number of Ames Member samples available contributed to increased variability (see text for discussion). Points represent megaguild abundance and are represented by the same symbols as on the other gradients in this paper. The data have been fit with a polynomial trend-line to illustrate their distribution which reflects biofacies variation along an environmental continuum. Each biofacies' peak abundance is labeled 15 corresponding to the dominant megaguild. The two discernable peaks in the abundance of Biofacies 1 are the INBIV and CRURI megaguilds that compose that biofacies. 
3.0.0.0. Evidence for faunal tracking in recurrent fossil assemblages in four major marine zones

in the Glenshaw Formation (Upper Pennsylvanian, Appalachian Basin)

Joseph G. Lebold

\subsubsection{ABSTRACT}

The Upper Pennsylvanian Glenshaw Formation contains a series of marine zones that were deposited on the detrital slope of the Appalachian highlands during the last major transgressions from the Midcontinent Sea in the Paleozoic of eastern North America. These marine zones contain fossil assemblages that can be characterized as biofacies that inhabited a variety of shallow marine environments. The goals of this study were to 1 ) determine if the four biofacies in the Glenshaw marine zones recurred with a distinctive composition-abundance structure during each marine episode, 2) examine the stratigraphic distribution of recurrent biofacies to determine if they tracked a preferred habitat, 3) examine the distribution of individual genera within biofacies to determine the degree of association among the constituent taxa.

The results of this study indicate that marine zones in the Glenshaw Formation contain four biofacies that recur in more than one marine zone, and are positioned along an environmental gradient that represents changing conditions associated with nearshore to offshore settings. These four biofacies re-appear with a distinctive composition-abundance structure tracking a preferred set of environmental conditions related to glacio-eustatic sea-level changes in the Appalachian Basin. A symmetrical (Nearshore-offshore-Nearshore) pattern is found in only one marine zone, whereas, the asymmetrical (Offshore-Nearshore) biofacies pattern found in three of the four marine zones is attributed to relatively rapid rates of transgression commonly associated with glacio-eustatic cycles.

The eight most abundant genera were non-randomly distributed among the four Glenshaw biofacies, indicating a consistent environmental preference. In contrast, only four of the remaining 15 less abundant genera were non-randomly distributed. The abundant taxa maintain a more consistent membership among the four biofacies by tracking their preferred environment. An inherent aspect of environmental tracking is that species respond independently, leading to variations in the taxonomic structure of faunal assemblages. The fact that nearly half of the genera that compose the four Glenshaw biofacies are randomly distributed illustrates this variation. 


\subsubsection{INTRODUCTION}

Recent studies in the Midcontinent Basin (Holterhoff, 1996; Olszewski and Patzkowski, 2001) and the Appalachian Basin (Bennington and Bambach, 1996) have explored patterns in fossil assemblages collected from the marine portions of Pennsylvanian cyclothems. These studies are concerned with the degree of biological integration or taxonomic association among organisms that comprise larger biologically-defined assemblages commonly designated as biofacies, or paleocommunity types (sensu Bennington and Bambach, 1996), that track their preferred habitat through successive episodes of sea-level change. The migration of faunal assemblages in response to changes in the benthic environment has been referred to as community replacement (Rollins et al., 1979; Miller, 1986). However, Brett et al. (1990) applied the term "faunal tracking" to further emphasize the relationship between shifting benthic assemblages and their preferred environments.

Although faunal tracking itself implies no inherent cause or process for the observed pattern, two mechanisms have been evoked to account for this pattern (Holterhoff, 1996). One alternative involves the "environmental selection" (Bambach, 1994) of taxa with similar habitat preferences/tolerances leading to consistent faunal associations. Taxa inhabit their preferred environment until conditions within those environments change enough to cause the collapse and re-establishment of the local ecosystem. This model emphasizes the individualistic response of taxa to environmental processes in shaping the underlying structure of faunal assemblages. The second alternative involves the establishment of internally-regulated ecosystems that are buffered from minor environmental fluctuations by consistent biological associations among the constituent taxa (Morris et al., 1995). These ecosystems remain stable until some threshold of environmental disturbance, fatal to the ecosystem, is reached causing rapid collapse and 
subsequent re-establishment. This mechanism stresses the importance of ecological interactions among constituent taxa that inhibits anagenetic (within lineage) speciation and the successful establishment of immigrating taxa. These low-level associations are thought to maintain the rank abundance and guild structure within assemblages, which is known as ecological locking (O'Neill et al., 1986).

Marine zones within the Glenshaw Formation of the Appalachian Basin should provide an ideal setting to analyze patterns of biofacies recurrence. Four geographically-widespread marine zones, separated by thick nonmarine intervals, provides a unique, natural experiment in the collapse and re-organization of the local benthic ecosystem. The relationship between faunal assemblages and their environments can be confidently examined because faunal variation within each marine zone is not likely the result of evolutionary processes, which generally are on the order of millions of years (Dodd and Stanton, 1990). Classification methods (cluster analysis and multidimensional scaling) and discriminant analysis were used to identify groupings within fossil assemblages collected from the Glenshaw Formation. The taxonomic distinctiveness between these groups, and associations among the constituent taxa within these groups, were analyzed using canonical variance analysis (CVA). The results are compared to those of other recent studies that identified recurrent assemblages in sea-level cycles of similar duration.

\subsubsection{STRATIGRAPHIC FRAMEWORK}

The Upper Pennsylvanian Conemaugh Group of the Appalachian Basin is subdivided into two formations, the Glenshaw and the Casselman (Figure 3-1), the former of which contains numerous thin marine zones distributed among thick sequences of nonmarine rocks (Flint, 1965). These marine zones record the distal extent of marine incursions from the Midcontinent Sea onto 
the distal shelf formed by the detrital slope of the Appalachian highlands (Heckel et al, 1998). Four of the most extensive marine zones were sampled for paleoecological analysis (Lebold and Kammer, this volume, submitted; Lebold, this volume, Chapter 2). They include (in ascending stratigraphic order with equivalent names for southwestern Pennsylvania in parenthesis); Lower Brush Creek (Brush Creek), Upper Brush Creek (Pine Creek), Cambridge (Nadine), and the Ames members. These marine zones are geographically widespread and considered major transgressions within the Glenshaw Formation (Martino et al., 1996).

Late Middle to Late Pennsylvanian glacial-eustatic changes in sea level were controlled by climate change induced by orbital cyclicity (Heckel, 1986). During deposition of the Middle to Upper Pennsylvanian units in the Appalachian basin, the major seaway that opened onto the midcontinent was located to the southwest (modern orientations), with the depositional axis oriented northeastward (Brezinski, 1983). The basin was bounded to the northwest by the Cincinnati Arch and to the southeast by the recently uplifted Appalachian highlands (Lamborn, 1951). Extensive research during the last two decades has reasonably established glacial-eustatic sea level change as the primary control over Pennsylvanian marine cyclothems in the Midcontinent region of the United States (Heckel, 1986; 1995). The Glenshaw Formation was deposited in an 8 m.y. interval between $302 \pm 4$ Ma and $294 \pm 6$ Ma (Heckel, 2002). The average duration for the major to intermediate cycles of Heckel (1986) is about 400 k.y. (Heckel, 2002), which corresponds to the 400 k.y. Milankovitch secondary eccentricity, or stretch, cycle (Imbrie, 1985). Thus, the Lower Brush Creek (Brush Creek), Upper Brush Creek (Pine Creek), Cambridge (Nadine), and Ames members, each as part of a major cycle, were each deposited in less than 400 k.y.

The Lower Brush Creek (Brush Creek) through Ames members range in age from basal 
Missourian (Lane et al., 1971; Smyth, 1974), to lowermost Virgilian (Lane et al., 1971; Wilde, 1975). Based on distinctive conodont faunas (Heckel et al., 1998): the Lower Brush Creek (Brush Creek) Member correlates with the Macoupin marine zone in the Illinois Basin and the Swope (Hushpuckney) marine zone in the Midcontinent Basin; the Upper Brush Creek (Pine Creek) Member correlates with the Shoal Creek marine zone in the Illinois Basin and the Dennis (Stark) marine zone in the Midcontinent Basin; the Cambridge (Nadine) Member correlates to the "Fithian"-Flat Creek marine zone in the Illinois Basin and the Dewey (Quivira) in the Midcontinent Basin; and the Ames Member correlates with the Shumway marine zone in the Illinois Basin and the Oread (Heebner) marine zone in the Midcontinent Basin.

\subsubsection{METHODS}

\subsubsection{Samples and Data}

Ninety-five bulk samples were collected from 20 outcrops in the northern Appalachian Basin (Figure 3-2 and Table 3-1). The samples were taken using 3.7 liter capacity bags at each obvious change in lithology or wherever a distinct faunal change occurred. In order to account for the patchy distribution of animals observed in most living marine communities, small bulk samples were taken laterally across the exposures within the same sampled layer where possible. These small bulk samples were combined in the lab prior to processing. Whole limestone blocks were taken from the outcrops with stratigraphic orientation recorded on the rock.

In the laboratory, the shale samples were washed, dried, and sieved. The use of surfactants to disaggregate the shales was abandoned early, due to breakage of thin shells and poor preservation evident within a few of the sampled units. With the aid of a binocular microscope, the shale samples were carefully disaggregated and fossils were removed using a 
pin-vice and small dental picks. Limestone blocks were washed and fossils on the outer surface were counted and recorded. The blocks were then carefully broken into smaller pieces and all observed taxa were tallied.

Most of the fossil-bearing units sampled for quantitative analysis represent low energy, mud-dominated (either carbonate or clastic) environments where no significant between-facies transport of shelly material would have occurred (Kidwell and Bosence, 1991). Limestones from the AMA, BELL, and CONC outcrops in southeastern Ohio contained size-sorted fossil grains and cross bedding indicating some transport of shelly material. However, for most benthic marine invertebrates, between-habitat transport of shelly material is rare in most settings, with exotic bioclasts composing only a minor component of most fossil assemblages (Kidwell and Flessa, 1995). The preservation of fossil material ranges from moldic in a few instances to exceptional. Although variations in preservation style and in the lithology of sampled units indicates that these fossil assemblages were subjected to different taphonomic processes, consistent physical disaggradation in the processing of all samples was employed to minimize collection bias.

Fossil data represents the sum of invertebrate fossils identifiable to the generic level within 60 final samples selected for analysis. Interval data (count data) have been shown to contain more information regarding the distribution of taxa than binary (presence-absence) data (Gauch, 1982), and the generic level has repeatedly been regarded as the appropriate taxonomic level to perform recurrence analysis (e.g., Holterhoff, 1996; Bennington and Bambach, 1996; Olszewski and Patzkowski, 2001). However, the stratigraphic range of two chonetid brachiopods, Chonetinella and Neochonetes, overlap only slightly among the four marine zones (Sturgeon and Hoare, 1968). Their distributions are disjunct as a result of evolutionary 
processes, but similarities in their mode of life (epifaunal, reclined suspension feeders) and shell morphology (flat, thin, unornamented shells) suggest that they employed similar life strategies. In order to minimize stratigraphic (evolutionary) bias, their occurrences will be combined into a single category representing all chonetid brachiopods tallied in this study.

The exclusion of fragmentary remains that could not be identified to the generic level (e.g., bryozoans) or disarticulate rapidly after death (e.g. crinoids) reduced the diversity of taxa analyzed in this study to articulate brachiopods, bivalves, and gastropods. Brachiopod and mollusc fossil counts were derived using the MNI (minimum number of individuals) method for fragmentary remains (Gilinski and Bennington, 1994). The number of genera was further reduced from 49 to 23 by selecting only those taxa representing the ten most abundant fossils in each biofacies. This reduced the number of variables (genera) indicates that the same genera were commonly found in more than one biofacies.

\subsubsection{Multivariate Analysis}

Classification methods such as multidimensional scaling (MDS) and cluster analysis were used to explore and identify patterns within samples (Q-mode) or variables (R-mode) utilizing the software package NTSYSpc-2.02i (Rohlf, 1998). The similarity index used for the Q-mode analysis was cosine theta, which is the appropriate similarity coefficient for Q-mode analysis (Joreskog et al., 1976). Pearson's similarity coefficient was used to calculate the degree of covariance of sample abundance between taxa (R-mode) (Sokal and Rohlf, 1981).

Hierarchical, agglomerative clustering analysis produces a dendrogram of objects that corresponds to the degree of similarity between those objects. Objects with the highest degree of similarity are grouped together first. The next most similar objects are then successively 
connected to these until all objects and groups are tied together at progressively lower levels of similarity. For this study, clustering was performed using the "unweighted pair-group method with arithmetic averaging" (UPGMA). A drawback to divisive techniques like cluster analysis is that objects are placed into discrete groups whether such groups exist in the data set or not. Inappropriate groupings can be constructed in data that are oftentimes gradational in nature.

Ordination techniques, such as MDS, can be employed to test for gradients within the data. MDS places objects (variables or samples) in low-dimensional, usually two or three, Euclidean space. The distance between objects corresponds to the complement of cosine theta (1-COSØ). Objects in close proximity are the most similar, whereas objects that plot away from each other are less similar. The goodness-of-fit is ranked by the stress index, which measures how well the similarity relationship among samples corresponds to the observed distance matrix. Stress values range from 0 to $1 ; 0.00$ is a perfect fit, values greater than 0.40 indicate a poor fit (Rohlf, 1998). Clustering and ordination methods are often most useful when they are used in tandem (Gauch, 1982). If the data are organized into discrete groups, this pattern would be confirmed by tightly-spaced data points in ordination space (Springer and Bambach, 1985).

Discriminant analysis was used to more rigorously test the groups identified by exploratory classification methods using the statistical software package Minitab, version 14 ( Minitab, Inc. 2003). In discriminant analysis, each sample is pre-assigned to a group using variables (taxa) as predictors based on a common distribution of fossil taxa. These groups are interpreted to reflect a distinctive set of environmental conditions that accounts for the withingroup taxonomic commonality. The purpose of discriminant analysis is to find the linear combination of all included variables that discriminate, or produce the maximum variation, between previously defined groups (Davis, 1986). Discriminant analysis of multiple variables is 
very similar to a multivariate analysis of variance (MANOVA) (SAS User's Guide, 2004 ).

Matrices of total and pooled within-group variance and covariance are compared using multivariate $\mathrm{F}$ tests to determine the presence of significant differences among the variable means across the groups. If the total, or between-groups, variance is significantly larger than the within-group variance, then the variable means are producing significant differences, or discriminating between groups. A more rigorous test of the sample assignment to groups can be performed during discriminant analysis by using cross-validation. This procedure omits the first observation (sample) from the data set, classifies the remaining samples, and then reclassifies the omitted observation to test if the observation is returned to its original group. The first sample is then returned to the data set and the process is repeated for every observation.

Once the sample groups were finalized in discriminant analysis, canonical variate analysis (CVA), which creates canonical variables to define the groupings, was used to calculate the statistical significance of the distances between group centers, or centroids, and graphically represent the results. CVA was performed using the CANDISC procedure of SAS, version 9.1 (SAS User's Guide, 2004). Like discriminant analysis, CVA seeks to combine the variance of distributions into linear combinations that effectively reduce the dimensionality of the data set. These combinations are the canonical variables and are much like eigenvectors calculated in principle components analysis (Holterhoff, 1996). However, the goal of CVA is the same as discriminant analysis: to discriminate between previously assigned groups by comparing withingroup variance to the total variance among all groups. The CANDISC procedure expands on the results of groups confirmed by discriminant analysis, by assigning pair-wise and pooled probabilities to the squared distances between group centroids, or Mahalanobis distances (DISTANCE option in SAS). Univariate analysis of variance was also performed to analyze the 
correlation of each variable (taxon) to the total canonical structure (ANOVA option in SAS) which is analogous to assessing the contribution that each variable made to differentiating samples into groups (Holterhoff, 1996).

Preliminary Q-mode cluster analysis of fossil counts segregated Glenshaw Formation samples into three groups: a Crurithyris-dominated cluster, a chonetid-dominated cluster, and a cluster that had a low occurrence of these two predominant taxa (not presented for brevity). The first two clusters have a "chain" topology, suggesting that samples were added one by one to a single cluster instead of being placed into clusters and then combined (Olszewski and Patzkowski, 2001). Considering that Crurithyris and the chonetids account for $60 \%$ of the total genera tabulated, the "chain" pattern suggests that clusters were primarily defined by the abundance of these two groups, which swamped the distribution of the remaining taxa. These brachiopods are known to employ opportunistic life strategies (Malinky and Heckel, 1998) that enable them to rapidly colonize environments when conditions are favorable (Levinton, 1970). In an attempt to subdue the overwhelming proportion of these opportunists, fossil counts for each sample were converted to natural log values (Table 3-2). This reduced the proportion of these two groups to $32 \%$ and increased the influence of the remaining subdominant taxa. For this reason, all remaining analysis will utilize the natural log transformed data. However, CVA will be performed on both standardized and unstandardized data to evaluate the effect of the data transformation. In addition to the three groups, two samples, CAMH2 and CONC formed their own branches on the cluster diagram due to a unique occurrences/abundance of certain taxa. Because they did not fit into any of the clusters, even with the tendency of cluster analysis to group objects with very low similarity, they were omitted from the remainder of the analysis. 


\subsubsection{RESULTS}

\subsubsection{Classification and Discriminant Analysis}

R-mode cluster analysis of variables (taxa) was performed on the natural log transformed data (Figure 3-3). With the exception of the brachiopod Crurithyris, genera collected from the Glenshaw Formation were classified into two distinct groups. The first group contains the articulate brachiopods Antiquatonia, Cancrinella, chonetids, Composita, Derbyia, Juresania, and Neospirifer, and the epifaunal bivalve, Aviculopecten. These taxa are epifaunal suspensionfeeders and have previously been associated with clear-water, normal marine, offshore environments in previous paleoecological studies and are herein classified as stenotopic (Stevens, 1971; Yancy and Stevens, 1981; Brezinski, 1983; Boardman et al, 1984; Olszewski and Patzkowski, 2001; Lebold, this volume, Chapter 2; Lebold and Kammer, this volume, submitted). The second group contains the bivalves Astartella, Dunbarella, Edmondia, Nuculopsis, Paleyoldia, and Phestia, the gastropods Donaldina, Euphemites, Girtyspira, Glabrocingulum, Knightites, Meekospira, and Pharkidonodus, and the productid brachiopod, Linoproductus. These taxa are tolerant of a wide range of salinities and turbidity levels generally associated with fluctuating conditions proximal to terrigenous sources (Stevens, 1971; Yancy and Stevens, 1981; Brezinski, 1983; Boardman et al, 1984; Olszewski and Patzkowski, 2001; Lebold, this volume, Chapter 2; Lebold and Kammer, this volume, submitted).

The articulate brachiopod Crurithyris comprised its own branch of the R-mode dendrogram (Figure 3-3). Crurithyris has been identified as an opportunist in previous paleoecological studies of the Pennsylvanian (Malinky and Heckel, 1998; Lebold, this volume,

Chapter 2; Lebold and Kammer, this volume, submitted) as well as eurytopic (Brezinski, 1983; Olszewski and Patzkowski, 2001; Lebold, this volume, Chapter 2; Lebold and Kammer, this 
volume, submitted). Most samples that contain a high proportion of Crurithyris contain few or no associated taxa, suggesting that Crurithyris is often the only taxon adapted to certain combinations of environmental variables. This is supported by the placement of Crurithyris on its own branch of the R-mode dendrogram, which indicates its rather unique distribution among samples.

Q-mode cluster analysis of the natural log transformed data produced three clusters (Figure 3-4). Samples containing an overwhelming proportion of the dominant opportunists Crurithyris and the chonetids still clustered together, but samples with a high proportion of subdominant taxa, namely molluscs, in addition to the opportunist brachiopods were discernible. However, the relatively large chonetid cluster still exhibited chain topology suggesting that many of the samples within this cluster were grouped at low similarity. To further evaluate the groupings produced by cluster analysis, a Q-mode MDS plot of samples was calculated. If the groupings were truly discrete, this would be reflected by the distribution of samples in lowdimensional space (Springer and Bambach, 1985). The results of Q-mode MDS positioned the sample groups identified by cluster analysis in low-dimensional space with a stress of 0.18 , which is good to fair (Rohlf, 1998; Figure 3-5). Although the results from the two techniques identified similar sample groups, the distance between points within a single sample group approached, and in some cases exceeded, the separation of points between sample groups (Fig. 5). This suggests that the three groups defined by cluster analysis are not truly discrete, and in particular, the relatively wide spread of samples assigned to the large chonetid cluster confirmed the initial observation that many of these samples were grouped at low similarity and that the large chonetid cluster may be an artifact of the divisive nature of cluster analysis.

Suspicion about the relevance of the large chonetid group increased when samples that 
contain a number of large stenotopic brachiopods derived from limestone layers were in the same cluster as samples that contained microgastropods derived from dark shales. To resolve this issue, discriminant analysis was performed on the sample groups identified during cluster analysis. The large chonetid cluster was hand-sorted into two groups based on sample lithology and faunal content using all taxa as predictors. The first iteration with cross validation indicated that 11 samples were misclassified in their predicted groups from cluster analysis. However, when samples are reclassified in discriminant analysis, there is a corresponding change in the variance that defines the groups. The researcher must carefully select the samples to reassign in order to prevent drastic changes in the group variance. Again using taxonomic distributions within samples as a guide, only six samples had to be reassigned on the next iteration before all samples were properly classified in discriminant analysis (Table 3-3). The four remaining groups included two from the large chonetid cluster plus the mollusc dominated cluster and the Crurithyris-dominated cluster.

To illustrate the groups distinguished by discriminant analysis, those results were combined with the results of R-mode cluster analysis into a variation on the two-way cluster diagram (Figure 3-6). This method permits visual analysis of the composition and abundance of individual taxa within samples. The results of two-way abundance analysis confirms that the large chonetid cluster was composed of samples with very different taxonomic compositions, and is more likely a combination of two sub-clusters. The first sub-cluster contains samples with a high proportion of chonetids with a variety of stenotopic brachiopods as accessory taxa.

Samples in the second sub-cluster still contain a fairly high abundance of chonetids (the reason they initially clustered together), but these samples have an increased proportion of molluscs, particularly the microgastropods Donaldina and Girtyspira, which were fairly uncommon in the 
other chonetid-dominated samples. The division within the chonetid samples was not well defined on the Q-mode dendrogram (Figure 3-5), but was readily discernable on the two-way plot (Figure 3-6). The four groups distinguished on the two-way diagram each contain a unique fossil assemblage that can be characterized as a biofacies. The biofacies are labeled: Mollusc, Chonetid-mollusc, Chonetid, and Crurithyris according to the predominant genus (or genera) in the included samples. Overlap in the faunal distributions within these labeled biofacies indicates that discrete faunal assemblages are not present and that intergrading faunal assemblages exist, making the placement of samples into groups somewhat arbitrary. This reflects practical limitations when placing objects (samples) that exist along a continuum into groups, but it does not overshadow the usefulness of assigning samples to a particular faunal type (e.g., nearshore and offshore) when describing faunas (Gauch, 1982).

The groupings confirmed by discriminant analysis contain samples from more than one of the Glenshaw marine zones. This indicates that the sample groups are not stratigraphically defined, and the distribution of samples in the classification analysis indicates that similar marine assemblages periodically colonized the seafloor in response to a similar set of environmental conditions established during the four marine transgressions in the Glenshaw Formation. This scale of recurrence among groups defined by clustering and ordination classification methods is similar to that of the paleocommunity type (sensu Bennington and Bambach, 1996).

\subsubsection{Recurrence analysis}

CVA analysis, as a tool for recurrence analysis, was performed to more rigorously test the distinctiveness of the four groups defined by discriminant analysis in Minitab. Both raw counts and natural log transformed values were tested to evaluate any possible distorting effects 
from data transformation. Both data sets produced similar results. However, only the results of the natural log data, which were used consistently throughout this analysis, will be presented.

The CANDISC function in SAS permits the researcher to select the number of canonical variables to be computed. The maximum number of variables must be less than or equal to the number of variables, or the number of $a$ priori defined groups, minus one (SAS User's Guide, 2004). Because the number of groups in this analysis is equal to four, three canonical variables were computed during this test. The results of CVA indicates that the first two canonical variables had the highest combined discriminatory power, accounting for $96 \%$ of the variability in the natural log transformed data. The first canonical variable accounted for nearly $63 \%$ of the variance, whereas the second accounted for 33\%. A plot of canonical variables one and two shows the distribution of Glenshaw samples grouped within distinct regions in multivariate space (Figure 3-7A). The Bivalve and Crurithyris biofacies are positively correlated with canonical variable 1 , and the Chonetid and Chonetid-gastropod biofacies are negatively correlated with canonical variable 1 . The brachiopod-dominated biofacies (Chonetid and Crurithyris) are negatively correlated with canonical variable 2, whereas biofacies with a significant mollusc proportion (Bivalve and Chonetid-gastropod) are positively correlated with canonical variable 2 .

Groups of samples are composed entirely of samples from a single biofacies, which confirms the results of discriminant analysis that these biofacies, or paleocommunity types, have a distinctive taxonomic composition. All four groups also contain samples from more than one marine zone, which also confirms the results of discriminant analysis that these biofacies are recurrent (Table 3-4). Pair-wise comparisons of the generalized squared distances, or Mahalanobis $\mathrm{D}^{2}$, between groups indicates that the distance between biofacies centroids was 
significant at the 0.0001 level (Table 3-5). Pooled comparisons of the four biofacies were made using various statistics that test the significance of the Mahalanobis distances (Table 3-6). The comparisons all show that the biofacies means are significantly different. The results of both the pair-wise and pooled comparisons indicate that the distance between biofacies centroids is statistically significant in taxonomic, or variable space.

The second plot (Figure 3-7B) shows the correlation $\left(\mathrm{R}^{2}\right)$ between the original variables (taxa) and canonical variables one and two. This graphically represents the contribution of each variable to the total canonical structure (Holterhoff, 1996). The majority of brachiopods and gastropods are negatively correlated with canonical variable 1 and the majority of the bivalves and the brachiopod Crurithyris are positively correlated with canonical variable 1. This accounts for the separation between the bivalve and Crurithyris biofacies from the chonetid and chonetidgastropod biofacies (Figure 3-7A). With the exception of Linoproductus, all brachiopods are negatively correlated with canonical variable 2, and all molluscs, without exception, are positively correlated with canonical variable 2 . This accounts for the wide separation of brachiopod-dominated biofacies from mollusc-dominated biofacies along this axis (Figure 37A). One of the most striking features of this plot is the separation between the chonetid brachiopods, which are strongly negatively correlated with canonical variable 1, and Crurithyris, which is strongly positively correlated with canonical variable 1 . This accounts for the wide separation between the two brachiopod-dominated biofacies.

Table 3-7 shows the results of univariate ANOVA tests of class (biofacies) means. This is the probability that the class (biofacies) means for each variable are equal in all four biofacies. If the class means are significantly similar, than the variables (taxa) in the data set are randomly distributed among the four biofacies. Twelve of the 23 taxa that compose these biofacies are 
non-randomly distributed at the $5 \%$ significance level (Table 3-8). Ten of the twelve taxa that are non-randomly distributed are molluscs, the remaining two are the chonetid brachiopods and Crurithyris. The fact that over half of the taxa in this study are non-randomly distributed is not surprising given the relatively wide separation of these biofacies centroids in multivariate space.

\subsubsection{DISCUSSION}

\subsubsection{Environmental Interpretation}

The majority of variance (63\%) among the distribution of taxa within samples is accounted for by the first canonical variable. This variable separates the Bivalve and Crurithyris biofacies on the positive end of this canonical axis, from the Chonetid and Chonetid-gastropod biofacies on the negative end (Figure 3-7A). The Bivalve Biofacies is composed primarily of the infaunal deposit-feeding bivalves Nuculopsis, Phestia, and Paleyoldia; the infaunal suspensionfeeding bivalves Astartella and Edmondia; and the infaunal to semi-infaunal, deposit-feeding gastropod, Euphemites. These taxa burrowed into the sediment presumably to feed on the organic detritus. These molluscs have also been associated with nearshore environments in Pennsylvanian sea-level cycles and have been classified as eurytopic with respect to turbidity and variable salinity (Brezinski, 1983; Yancy and Stevens, 1984; Boardman, 1984; Lebold, this

volume, Chapter 2; Lebold and Kammer, this volume, submitted). The brachiopod Crurithyris, the dominant component of the Crurithyris Biofacies, is a pedically-attached epifaunal suspension feeder. This brachiopod possessed a relatively thick, strongly-convex shell with a short hinge line commonly associated with environments under the influence of persistent local currents (Ager, 1965). Like the infaunal molluscs in the Bivalve Biofacies, Crurithyris has also been associated with nearshore settings (Brezinski, 1983; Yancy and Stevens, 1984; Boardman, 
1984; Lebold, this volume, Chapter 2; Lebold and Kammer, this volume, submitted). However, Lebold (this volume, Chapter 2) recently concluded that Crurithyris was euryhaline and not especially tolerant of increased turbidity.

Samples assigned to the Chonetid and Chonetid-gastropod biofacies are negatively correlated with canonical variable 1 (Figure 3-7A). Chonetid brachiopods, which comprise the majority of taxa in these two biofacies, possessed a thin, flat shell with a long hinge line that is nearly as long as the entire width of their shell. Although brachiopods do require some influence of local currents to bring food to their feeding structures (Jorgenson, 1966), this shell morphology has been associated with quiet-water settings (Ager, 1965). In addition, previous studies of Pennsylvanian faunal assemblages concluded that chonetid brachiopods are commonly associated with offshore, normal marine conditions (e.g., Nuhfer, 1979; Brezinski, 1983; Boardman et al.,1984; Malinky and Heckel, 1998; Olszewski and Patzkowski, 2001).

Although the Chonetid and Chonetid-gastropod biofacies are both negatively correlated with canonical variable 1, the Chonetid-gastropod Biofacies has a slightly greater negative correlation (Figure 3-7A). The offset can be explained by analyzing the environmental preferences of the subdominant taxa associated with the chonetid brachiopods in these two biofacies. The Chonetid Biofacies contains the highest combined proportion of the suspensionfeeding brachiopods Neospirifer, Antiquatonia, Juresania, Cancrinella, Linoproductus, Composita, and Derbyia among biofacies. Like most suspension feeders, these taxa would require at least some influence of local currents (Jorgenson, 1966). In contrast, the Chonetidgastropod Biofacies contains a significant proportion of the epifaunal, deposit-feeding, microgastropods Donaldina and Girtyspira. These microgastropods are capable of inhabiting environments with reduced local currents that would permit previously deposited muds to 
compact, increasing substrate firmness, and permit the accumulation of organic detritus on the substrate. Epifaunal deposit feeders would benefit from both a firmer substrate for locomotion, and the accumulation of organic detritus as a readily available food source.

The first canonical axis is interpreted as a nearshore-offshore gradient, which is consistent with interpretations of the first composite-variable axis constructed using eigenvector methods, such as detrended correspondence analysis (DCA), in previous paleoecological studies (e.g., Olszewski and Patzkowski, 2001; Holland and Patzkowski, 2004). Samples that are positively correlated with the first axis are positioned on the nearshore end of the gradient, and samples that are negatively correlated with the first axis fall on the offshore end of the gradient.

Biofacies distribution along canonical variable 2 is quite different from canonical variable 1 (Figure 3-7A). This canonical variable separates the brachiopod-dominated Chonetid and Crurithyris biofacies from the Bivalve and Chonetid-gastropod biofacies that contain a high proportion of molluscs. This separation essentially divides epifaunal suspension-feeders, represented by the brachiopod-dominated biofacies, from the epifaunal and infaunal depositfeeders and grazers, represented by the increased molluscan proportion in the other two biofacies. Therefore, the environmental factor represented by canonical variable 2 must have a direct effect on the different feeding strategies of these two groups. Brachiopods depend on capturing food suspended in the water column, whereas deposit-feeding bivalves and gastropods obtain most of their food from within or on the surface of the substrate, respectively. The accumulation of organic matter on or within the sediment requires the influx of detrital material. In nearshore environments proximal to terrigenous source areas, a significant proportion of clastic material would most likely accompany the organic material settling out of suspension and incorporate it within the sediment. Offshore environments can also receive consistent amounts of 
detrital influx from terrigenous sources. However, organic detritus has a lower specific gravity when compared to clastic detritus and is often carried for a greater distance suspended in the water column after the clastics have settled proximal to the source area. In this situation, organic detritus would more likely accumulate on the substrate than within the substrate. In addition to an available food source, the influx of freshwater can periodically produce estuarine circulation characterized by a stratified water column as lighter, well oxygenated fresh water pools on the surface limiting vertical circulation (Heckel, 1991). Evidence of low-oxygen conditions is evident in many of the samples assigned to the Bivalve and Chonetid-gastropod biofacies. Ten of the 12 samples assigned to the Chonetid-gastropod biofacies and half of the samples assigned to the Bivalve Biofacies were taken from dark shales. Low-oxygen bottom waters would preserve organic detritus accumulating on or in the substrate that would normally be oxidized in well-oxygenated environments, leading to the deposition of dark shales (Demaison and Moore, 1980). In addition, the mollusc proportion in these two biofacies have a small $(<5 \mathrm{~mm})$ body size and are predominately deposit feeders. Decreased body size may either reduce the oxygen demand required per unit volume of tissue by an organism, or redirect metabolic processes away from growth to reproductive functions thereby increasing the number of offspring (Hallam, 1965; Mancini, 1978). These adaptations are characteristic of fossil assemblages that inhabited oxygen-deficient environments (Kammer et al., 1986).

The separation of the Bivalve Biofacies from the Crurithyris Biofacies along canonical axis 2 further supports the idea that the activity of terrigenous sources did not consistently effect all nearshore environments equally in the seas developed during Glenshaw times. Joeckel (1995) concluded that the influence of terrigenous sources was largely centered on the southeastern margin associated with the recently-uplifted Appalachian highlands. In a recently-published 
sequence stratigraphic model of the Glenshaw Formation, Martino (2004) concluded that influence of deltas was not as widespread in the Glenshaw Formation as previously thought. The second canonical axis is interpreted to represent proximity to terrigenous sources. Samples that are positively correlated with the second canonical axis are proximal to terrigenous sources, whereas samples that are negatively correlated along this axis are distal to terrigenous sources.

The environmental factors represented by the two canonical variables can be related to the degree of environmental stability. Along the first canonical axis, the degree of environmental stability would be lower on the positive end of the axis as the physical environment changes from variable conditions in nearshore settings to relatively stable conditions in offshore settings (Springer and Bambach, 1985). The degree of environmental stability also varies along the second canonical axis due to the influence of terrigenous sources. The influx of nutrients, clastic material, and freshwater would decrease the degree of environmental stability (Springer and Bambach, 1985; Elias and Young, 1996) on the positive end of the second canonical axis. Decreased environmental stability would have favored the success of eurytopic genera, which fall on the positive ends of both canonical axes, and account for a significant number of taxa in the Bivalve, Crurithyris, and Chonetid-Gastropod biofacies. Increased environmental stability in offshore environments, away from the influence of terrigenous sources, would have favored the success of the stenotopic brachiopods that negatively correlate with both canonical axes.

\subsubsection{Recurrence and Faunal Tracking of Glenshaw Biofacies}

Figure 3-8 shows the composite distribution of Glenshaw biofacies within the four major marine zones examined in this study. The asymmetrical pattern (offshore-nearshore) of biofacies distribution among the four marine zones strongly suggests that these faunal assemblages were 
tracking their preferred environments in response to sea-level changes in the Appalachian Basin. Pleistocene glacial-eustatic cycles exhibit asymmetric rates of ice volume fluctuation that can produce rapid transgressions and slow regressions (Denton and Hughes, 1983), and its likely that Late Paleozoic cycles were asymmetric as well (Heckel, 1986). Asymmetrical glacial-eustatic sea-level cycles results in variations in the duration and preservation of marine environments established during the transgressive and regressive phases of each marine episode. Rapid transgression can be recognized by the lack of the nearshore Bivalve and Crurithyris biofacies at the base of three out of the four marine zones as offshore conditions were quickly established in most parts of the basin (Figure 3-8).

Asymmetrical biofacies patterns result from variations in the activity of terrigenous sources throughout the transgressive-regressive cycle (Brett, 1998). Epifaunal suspension feeders tend to dominate the transgressive portion of the cycle as turbidity levels are reduced in response to nearshore sediment entrapment. Conversely, the emptying of such coastal sediment traps in response to, or as a result of, relative sea level fall should increase terrigenous influx to many parts of the basin (Posamentier et al., 1988). Epifaunal and infaunal deposit-feeding organisms tend to dominate the regressive portions of sea-level cycles in response to an increase in particulate food that accompanies the finer-grained portion of siliciclastic sediments, as well as an increase in substrate instability (Fürsich, 1978). This should produce a consistent offshorenearshore alternation of only two biofacies, one dominated by epifaunal suspension feeders, and one composed predominantly of epifaunal and infaunal deposit feeders. However, the identification of four distinct biofacies, Chonetid and Chonetid-gastropod biofacies that presumably preferred offshore conditions, and the Bivalve and Crurithyris biofacies that preferred nearshore conditions, in the Glenshaw marine zones indicates a more complex pattern 
of biotic response to relative sea-level change. The presence of two distinct biofacies that occupy the same inferred depth ranges and recur with a consistent composition-abundance structure suggests that these biofacies were laterally displaced, tracking variations in terrigenous influx as well as depth (Brett, 1998).

Within the Ames marine zone, a second, higher order of cyclicity is evident by repetition of the asymmetric sequence in Figure 3-8. The lack of nearshore biofacies in the first, stratigraphically-lower asymmetric sequence in some of the Ames marine zone exposures suggests that the mid-Ames regression may not have been accompanied by a significant change in relative sea level. Rather, the shift from the Chonetid Biofacies to the Chonetid-gastropod biofacies may simply represent an increase in the activity of terrigenous sources caused by either a minor change in relative sea level, or a reduction in the rate of sea level change (Brett, 1998).

The presence of recurrent biofacies in the four Glenshaw marine zones indicates that a similar set of environmental conditions were also recurring in the four transgressive-regressive cycles. However, not all four biofacies are represented in each marine zone (Figure 3-8 and Table 3-4) suggesting that some environmental parameter, unique to each the four marine zones, may be accountable for the lack of consistent biofacies recurrence. One such parameter that did vary with each transgression was the magnitude of marine inundation (Busch, 1984; Busch and West, 1987). Figure 3-9 shows the relative extent of the four marine transgressions. A comparison between the relative magnitude of each transgression and the number of biofacies present in each of the four marine zones indicates that the most extensive marine transgression, the Ames, contains all 4 biofacies. In contrast, the least extensive transgression, the Cambridge (Nadine), contains only two biofacies. The two medial transgressions, the Lower Brush Creek (Brush Creek) and Upper Brush Creek (Pine Creek) contain three biofacies. 
The relationship between the extent of transgression and biofacies variation may be related in part to the increased surface area available for colonization by benthic invertebrates in the more extensive transgressions and the reduced surface area in the less extensive transgressions. However, variations in surface area (i.e., habitat availability) does not account for the larger number of samples, 37, that contain the offshore (Chonetid and Chonetidgastropod) biofacies when compared to the number of samples, 19, that contain the nearshore (Crurithyris and Bivalve) biofacies, even when the 3 additional samples that contain an offshore biofacies deposited during the second sea-level cycle in the Ames are taken into account. The relationship between the extent of transgression and the stratigraphic distribution of biofacies may also be related to the preservation potential of asymmetric biofacies sequences. Within these sequences, the basal assemblages represent the offshore portion of a sea-level cycle, and the upper assemblages represent the nearshore portion of the sea-level cycle (e.g., Figure 3-8). The upper (nearshore) assemblages would inherently be more prone to erosion either during the final stages of the current sea-level cycle or the post-depositional phase. This would reduce the number of samples that contain nearshore biofacies when compared to the number of samples that contain offshore biofacies.

Faunal tracking of biofacies in the fossil record has been previously explained by two mechanisms. The ecological locking model (Morris et al., 1995) and the environmental-tracking model (Brett et al., 1990; Brett and Baird, 1995). The ecological-locking model suggests that interspecific associations among the constituent taxa in a given faunal assemblage buffer that assemblage from any significant changes in the composition-abundance structure. The environmental-tracking model suggests that taxa that compose benthic assemblages respond independently to changing environmental conditions, keeping pace with their preferred habitat. 
An inherent feature in the environmental-tracking model is that if species are responding independently, the composition-abundance structure of the migrating faunal assemblage will not be rigidly maintained (Valentine, 1973). The distribution of taxa among the Glenshaw biofacies in Table 3-7 indicates that the eight most abundant genera persist through each successive marine zone with a consistent, non-random distribution among the four biofacies each time their preferred environment is established. Whereas 11 of the 15 remaining less common genera are randomly distributed among the four biofacies, presumably in response to environmental changes that do not affect the most abundant genera. The fact that nearly half of the genera are randomly distributed among the four biofacies suggests that the Glenshaw biofacies are composed of loosely-structured assemblages, which is consistent with the independent response of taxa implied in the environmental-tracking model. It should be noted at this point that generalizations about the composition-abundance structure of Glenshaw biofacies could have been affected by other factors as well. For example, it has been demonstrated that uncommon or rare species are inherently less-tightly integrated into ecosystems as a whole (McKinney et al., 1996) and may account for the random distribution of the less common taxa. In addition, rare taxa produce fewer hard parts when compared to abundant taxa and may be more susceptible to taphonomic processes (e.g., the "taphonomic mirage" of Miller, 1993). However, differences in preservational conditions led to the decision to abandon chemical processing of shale samples to minimize the breakage of thin bivalve shells, thereby minimizing collection bias associated with differential dissolution of hard parts.

The apparent ecological stability of abundant genera in the Glenshaw marine zones, represented by the recurrence of persistent taxa through the successive collapse and reorganization of local ecosystems, coincides with a period of reduced origination and extinction 
of marine animal genera during the Late Paleozoic ice ages (Stanley and Powell, 2003). The most significant reductions in the origination and extinction of species would have occurred in shallow seas adjacent to glaciated landmasses at higher latitudes, where cool and highly-seasonal climate fluctuations were inferred to have broadened the ecological niches and geographic ranges of species, depressing rates of speciation, and leading to large and relatively stable populations (Stanley and Powell, 2003). However, the distribution of climatically-sensitive lithofacies (coals and leached paleosols deposited during wet periods, and carbonates and caliche during dry periods) suggests that increased seasonality extended to lower latitude landmasses as well (Cecil et al., 1990). Thus, a similar reduction in the origination and extinction of species should occur in the low latitude shallow seas that occupied the Appalachian Basin.

\subsubsection{Comparison to Related Studies}

Over the last decade, the paleoecological literature has been peppered with studies that seek to determine the degree of association among taxa that compose larger taxonomicallydefined recurrent or temporally-persistent fossil assemblages. The degree of association has been such an important topic because it has implications on the mechanisms (environmental vs biological) responsible for the pattern of coordinated stasis in which assemblages appear to persist for long periods of time interrupted by rapid turnover events (Brett and Baird, 1995). Recent studies on the ecological stability (stasis) of faunal assemblages yielded similar results to those of the present study that indicate environmental fluctuations were the predominant mechanism responsible for ecological stability (e.g., Bennington and Bambach, 1996; Holterhoff, 1996; Patzkowski and Holland, 1997; Olszewski and Patzkowski, 2001; Bonuso et al., 2002a, 2002b; Sanchez et al., 2002; Holland and Patzkowski, 2004). 
Comparisons within this section will focus primarily on studies from other Pennsylvanian sea-level cycles in either the Midcontinent or the Appalachian basin that were deposited on a similar temporal and geographic scales (Bennington and Bambach, 1996; Olszewski and Patzkowski, 2001). All of these, like the present study, were based on individual site collections rather than basin-wide compilations to test for the recurrence of similar taxonomic-abundance compositions both within and between biofacies in the marine portions of Pennsylvanian stratigraphic cycles.

Bennington and Bambach (1996) examined faunal assemblages from four marine units in the Middle Pennsylvanian Breathitt Formation. Like the present study, the four marine units represent major transgressions of the Midcontinent Sea into the Appalachian basin that recurred at a comparable temporal scale ranging between 400 k.y. and 2.5 M.y. The Breathitt marine units contain many of the same genera, and in some cases, similar biofacies as the data presented herein. The goal of their study was to establish a "base-level of variability" within faunal assemblages found at a single outcrop, which they termed paleocommunities, in order to determine how similar fossil assemblages had to be before they could be considered to be from the same underlying population. This base-level variability within paleocommunities would permit the identification of similar paleoecological assemblages at larger temporal and geographic scales. They found significant differences in the taxonomic-abundance structure from assemblages both within and between Breathitt marine units. Recurrence occurred only at the level of paleocommunity type, analogous to biofacies recurrence identified in the present study, but the taxonomic-abundance structure within biofacies and/or paleocommunity types is not rigidly maintained.

Olszewski and Patzkowski (2001) examined collections of Pennsylvanian-Permian 
bivalves and brachiopods from cyclothems of the northern Midcontinent. They determined the presence of two biofacies, one dominated by brachiopods and one dominated by bivalves, that recurred each time marine conditions were re-established in the basin. The two recurrent biofacies were taxonomically distinct, but the internal organization of species along the environmental gradient within each biofacies was not. Groups of genera that defined the gradients did recur to some extent, but the specific, pair-wise associations between taxa were not statistically distinguishable from random associations. They concluded that the distinctiveness of the brachiopod and bivalve biofacies most likely reflects different environmental preferences between these groups rather than interspecific associations among the constituent genera.

In general, these studies are consistent with the findings in the present study that taxonomically distinct biofacies, or paleocommunity types, recur among successive sea-level cycles. These biofacies even maintain their distinctiveness through periods of non-marine influence, which causes the repeated complete collapse and reconstruction of marine biofacies from their constituent taxa. However, the specific taxonomic-abundance structure of biofacies, represented by the taxonomic composition of individual samples, are not rigidly maintained. The lack of consistent taxonomic membership among samples most likely reflects the cooccurrence of taxa with similar environmental preferences and tolerances rather than the presence of biofacies with biologically-mediated interspecific associations.

\subsubsection{CONCLUSIONS}

Paleoecological and multivariate analysis of faunal assemblages collected from four major marine zones in the Upper Pennsylvanian Glenshaw Formation of the Appalachian Basin reveals the presence of four taxonomically-distinctive biofacies. These biofacies are labeled 
Bivalve, Chonetid, Chonetid-gastropod, and Crurithyris after a characteristic taxon or suite of taxa that numerically dominate their abundance.

The four biofacies identified in this study recur in more than one marine zone, and are positioned along an environmental gradient, recognized during CVA analysis, that represents changing conditions associated with nearshore to offshore settings. These four biofacies reappear with a distinctive composition-abundance structure tracking a preferred set of environmental conditions in response to glacio-eustatic sea-level changes in the Appalachian Basin. The asymmetrical (Offshore-Nearshore) biofacies pattern found in three of the four marine zones is attributed to relatively rapid rates of transgression commonly associated with glacio-eustatic cycles.

The results of CVA indicate that the eight most abundant genera were non-randomly distributed among the four Glenshaw biofacies, indicating a consistent preference for a particular set of environmental conditions. In contrast, only four of the remaining 15 less common genera were non-randomly distributed, indicating that the taxonomic structure of the four Glenshaw biofacies is not rigidly maintained during the collapse and re-organization of benthic marine assemblages. The lack of tight-knit associations among the constituent genera is consistent with the environmental-tracking model, which predicts that taxa respond independently to their environment. The abundant taxa maintain a more consistent membership among the four biofacies by tracking their preferred environment, whereas the less common genera are more likely responding independently to variations in the environment that do not affect the overall distribution of the most abundant genera. 
Table 3-1: Locations of sampled Glenshaw Formation outcrops.

Sample labels contain a code for the marine zone: LBC, BC = Lower

Brush Creek, Brush Creek; UBC, PC = Upper Brush Creek, Pine Creek;

CAM, NA = Cambridge, Nadine; and AM = Ames. Last letter indicates

a geographical reference point: $\mathrm{H}=$ Huntington, WV; $\mathrm{P}=$ Pittsburgh, $\mathrm{PA}$;

$\mathrm{W}=$ Wellersburg, $\mathrm{PA}$; Y= Youghiogheny River Lake; and A = Athens, $\mathrm{OH}$.

\begin{tabular}{|c|c|c|}
\hline Sampled Member & County, State & UTM coordinates (zone 17) \\
\hline Ames (AMH) & Lawrence, KY & $4233480 \mathrm{~N}, 358880 \mathrm{E}$ \\
\hline Cambridge (CAMH) & Wayne, WV & $4235420 \mathrm{~N}, 366280 \mathrm{E}$ \\
\hline Lower Brush Creek (LBCH) & Lawrence, KY & $4247320 \mathrm{~N}, 351780 \mathrm{E}$ \\
\hline Upper Brush Creek (UBCH) & ) Lawrence, KY & 4218340N, 357360E \\
\hline Ames (AMP) & Allegheny, PA & $4491800 \mathrm{~N}, 602540 \mathrm{E}$ \\
\hline Brush Creek (BCP) & Armstrong, PA & $4517960 \mathrm{~N}, 625420 \mathrm{E}$ \\
\hline Nadine (NAP) & Allegheny, PA & $4484520 \mathrm{~N}, 597140 \mathrm{E}$ \\
\hline Pine Creek (PCP) & Armstrong, PA & $4517740 \mathrm{~N}, 625460 \mathrm{E}$ \\
\hline Ames (AMW) & Somerset, PA & $4399280 \mathrm{~N}, 684440 \mathrm{E}$ \\
\hline Brush Creek (BCY) & Fayette, PA & $4402040 \mathrm{~N}, 637080 \mathrm{E}$ \\
\hline Nadine (NAY) & Somerset, PA & 4404920N, 638640E \\
\hline Pine Creek (PCY) & Somerset, PA & $4402220 \mathrm{~N}, 638100 \mathrm{E}$ \\
\hline Ames (AMA) & Athens, $\mathrm{OH}$ & $4352350 \mathrm{~N}, 405010 \mathrm{E}$ \\
\hline *Anmore (ANMO) & Harrison, WV & $4342200 \mathrm{~N}, 560720 \mathrm{E}$ \\
\hline *Belle Valley (BELL) & Noble, $\mathrm{OH}$ & $4403400 \mathrm{~N}, 452580 \mathrm{E}$ \\
\hline *Belington (BELN) & Barbour, WV & $4320800 \mathrm{~N}, 592810 \mathrm{E}$ \\
\hline *New Concord (CONC) & Guernsey, OH & $4426080 \mathrm{~N}, 440800 \mathrm{E}$ \\
\hline *Fairmont (FAIR) & Marion, WV & $4371680 \mathrm{~N}, 579220 \mathrm{E}$ \\
\hline *Greenbag Road (GRR) & Monongalia, WV & $4386100 \mathrm{~N}, 591560 \mathrm{E}$ \\
\hline *Newport (NEW) & Washington, $\mathrm{OH}$ & $4360040 \mathrm{~N}, 478240 \mathrm{E}$ \\
\hline
\end{tabular}

*Ames Member exposures along a NW-SE transect across the northern Appalachian Basin. 
Table 3-2: Natural-log transformed data set of brachiopod, bivalve, and gastropod genera from four marine zones in the Glenshaw Formation. Abbreviation for marine zones are: $\mathrm{LBC}(\mathrm{BC})=$ Lower Brush Creek (Brush Creek); UBC(PC)=Upper Brush Creek (Pine Creek); CAM(NAD) Cambridge (Nadine); and AMS=Ames. Refer to Table 3-1 for sample abbreviations. Key to Lithology codes: Clastics (ltSh-light shale, dkSh-dark shale); Carbonates (Ms-mudstone, Ws-Wackestone, Ps-packstone).

\begin{tabular}{|c|c|c|c|c|c|c|c|c|c|c|c|c|c|c|c|c|c|c|c|c|c|c|c|c|c|}
\hline 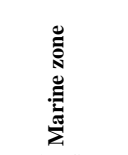 & 异 & 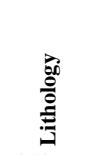 & 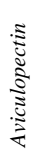 & 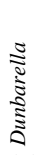 & 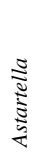 & 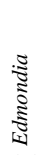 & $\begin{array}{l}\frac{n}{n} \\
\frac{a}{0} \\
\frac{3}{3} \\
z\end{array}$ & $\begin{array}{l}\frac{3}{0} \\
0 \\
0 \\
\frac{0}{0} \\
2\end{array}$ & $\begin{array}{l}\stackrel{\Xi}{\tilde{U}} \\
\frac{\widetilde{Z}}{\Omega}\end{array}$ & 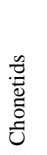 & 竝 & 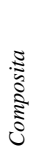 & 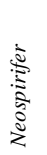 & 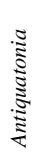 & 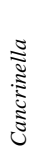 & 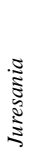 & 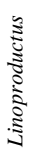 & 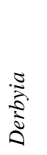 & 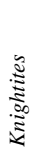 & 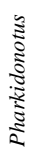 & 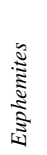 & 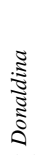 & 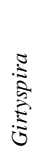 & 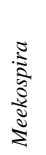 & 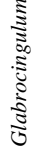 \\
\hline AMS & AMA1 & ltSh-Ps & 0.0 & 0.0 & 0.0 & 0.0 & 0.0 & 0.0 & 0.0 & 3.3 & 0.0 & 0.0 & 0.0 & 0.0 & 0.0 & 0.0 & 0.0 & 0.0 & 0.0 & 0.0 & 0.0 & 0.0 & 0.0 & 0.0 & 0.0 \\
\hline AMS & AMA3 & ltSh & 0.0 & 0.0 & 0.0 & 0.0 & 0.0 & 0.0 & 0.0 & 2.4 & 5.7 & 0.0 & 0.0 & 0.0 & 0.0 & 0.0 & 0.0 & 0.0 & 0.0 & 0.0 & 0.0 & 0.0 & 0.0 & 0.0 & 0.0 \\
\hline AMS & AMA5 & ltSh & 0.0 & 0.0 & 0.0 & 0.0 & 0.0 & 0.0 & 0.0 & 0.0 & 5.9 & 0.0 & 0.0 & 0.0 & 0.0 & 0.0 & 0.0 & 0.0 & 0.0 & 0.0 & 0.0 & .0 & 0.0 & 0.0 & 0.0 \\
\hline AMS & AMH1 & lt-dkSh & 1.6 & 0.0 & 0.7 & 0.0 & 4.3 & 2.4 & 1.4 & 4.6 & 0.0 & 0.0 & 0.0 & 1.1 & 0.0 & 1.8 & 1.6 & 0.0 & 2.1 & 0.0 & 1.4 & 0.0 & 1.1 & 0.0 & 4.2 \\
\hline AMS & AMH2 & Ms-Ws & 2.9 & 0.0 & 1.1 & 1.4 & 2.6 & 0.7 & 1.4 & 3.5 & 0.0 & 0.0 & 0.0 & 0.0 & 0.0 & 3.3 & 2.4 & 1.1 & 0.0 & 0.0 & 0.0 & .0 & 0.0 & 0.0 & 3.8 \\
\hline AMS & АМHЗ & ltSh & 0.0 & 0.0 & 0.0 & 0.0 & 3.3 & 0.0 & 1.9 & 5.1 & 0.0 & 0.0 & 0.0 & 0.0 & 0.0 & 1.4 & 0.0 & 0.0 & 0.7 & 0.0 & 1.6 & .0 & 0.0 & 0.0 & 4.3 \\
\hline AMS & AMH4 & ltSh-Ws & 1.6 & 0.0 & 0.0 & 0.0 & 0.0 & 0.0 & 0.0 & 5.2 & 0.0 & 0.0 & 0.0 & 0.0 & 0.0 & 0.0 & 0.7 & 0.0 & 0.0 & 0.0 & 0.0 & 0.0 & 0.0 & 0.0 & 0.0 \\
\hline AMS & AMP1A & Ps & 0.0 & 0.0 & 0.0 & 0.0 & 0.0 & 0.0 & 0.0 & 1.6 & 4.8 & 0.7 & 0.7 & 0.0 & 0.0 & 0.0 & 0.0 & 0.0 & 0.0 & .0 & 0.0 & .0 & .0 & 0.0 & 0.0 \\
\hline AMS & B & Js-lt & 0.0 & 0.0 & 0.0 & 0.0 & 0.0 & 0.0 & 0.0 & 1.8 & 5.8 & 0.0 & 0.0 & 0.0 & 0.0 & 0.0 & 0.0 & 1.4 & 0.0 & 0.0 & 0.0 & 0.0 & 0.0 & 0.0 & 0.0 \\
\hline AMS & AMW1 & Ps & 0.0 & 0.0 & 1.4 & 0.0 & 1.1 & 0.0 & 0.0 & 4.3 & 4.8 & 0.0 & 0.0 & 0.0 & 1.4 & 0.0 & 0.0 & 1.4 & 0.0 & 0.0 & 0.0 & .0 & 0.0 & 0.0 & 3.3 \\
\hline AMS & AMWOA & $\mathrm{kSh}$ & 0.0 & 0.0 & 0.0 & 0.0 & 0.0 & 0.0 & 0.0 & 0.0 & 5.7 & 0.0 & 0.0 & 0.0 & 0.0 & 0.0 & 0.0 & 0.0 & 0.0 & .0 & 0.0 & .0 & 0.0 & 0.0 & 0.0 \\
\hline AMS & 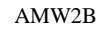 & Sh & 0.0 & 0.0 & 0.0 & 0.0 & 3.5 & 0.0 & 0.0 & 0.0 & 5.3 & 0.0 & 0.0 & 0.0 & 0.0 & 0.0 & 0.0 & 0.0 & 0.0 & 0.0 & 4.0 & 0.7 & 0.0 & 0.0 & 1.1 \\
\hline AMS & MW3 & kSh & 0.0 & 0.0 & 1.4 & 0.0 & 3.5 & 0.0 & 2.9 & 4.9 & 4.9 & 0.0 & 0.0 & 0.0 & 0.0 & 0.0 & 0.7 & 0.0 & 1.8 & 0.0 & 4.0 & 1.6 & 1.4 & 0.0 & 1.1 \\
\hline AMS & 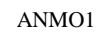 & Sh & 0 & 0.0 & 0.0 & 0.0 & 2.6 & 0.0 & 0.0 & 5.2 & 0.0 & 0.0 & 0.0 & 0.0 & 0.0 & 0.0 & 0.0 & 0.0 & 2.2 & .0 & 2.8 & 1.0 & 6 & 0.0 & 1.8 \\
\hline AMS & $\mathrm{O} 2$ & ltsh & 0 & 0.0 & 0.0 & 0.7 & 2.5 & 0.0 & 0.0 & 4.2 & 0.0 & 0.0 & 0.0 & 0.0 & 0.0 & 0.0 & 0.0 & 0.0 & 2.2 & 0.0 & 2.5 & 4.9 & 4.3 & 0.0 & 2.7 \\
\hline AMS & NMO3 & Ms-Ws & 0.7 & 0.0 & 0.0 & 0.0 & 2.6 & 0.0 & 0.0 & 5.5 & 0.0 & 0.0 & 0.0 & 1.1 & 1.1 & 0.7 & 3.3 & 0.0 & 0.0 & 0.0 & 0.0 & 0.0 & .0 & 0.0 & 0.0 \\
\hline AMS & 44 & lt-dk & 0.0 & 0.0 & 0.0 & 1.1 & 4.2 & 2.2 & 0.0 & 0.0 & 0.0 & 0.0 & 0.0 & 0.0 & 0.0 & 0.0 & 0.0 & 0.0 & 2.1 & 1.4 & 4.8 & .0 & .5 & 0.0 & 2.9 \\
\hline LBC(BC) & CP1 & $\mathrm{dkSh}$ & 0.0 & 0.0 & 0.7 & 0.0 & 0.7 & 0.0 & 0.0 & 2.1 & 1.8 & 0.0 & 1.4 & 0.0 & 0.7 & 0.0 & 0.0 & 0.0 & 0.0 & 0.0 & 0.0 & 0.0 & 0.0 & 0.0 & 1.8 \\
\hline LBC(BC) & 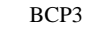 & Ws-dkS & 0.0 & 0.0 & 1.6 & 0.0 & 1.1 & 0.0 & 2.4 & 0.0 & 2.9 & 0.0 & 0.0 & 0.0 & 0.0 & 0.0 & 0.0 & .0 & 0.0 & 5 & .0 & .0 & 0 & 7 & .5 \\
\hline LBC & A & $\mathrm{dkSh}$ & 0.7 & 0.0 & 2.1 & 0.0 & 3.4 & 1.8 & 2.3 & 4.8 & 0.0 & 0.0 & 0.0 & 0.0 & 0.7 & 0.0 & 0.0 & 0.0 & 2.2 & 0.0 & 2.2 & 0.7 & .0 & 0.0 & 3.9 \\
\hline LBC(BC) & BCY2B & Sh & 0.0 & 0.0 & 2.8 & 0.0 & 4.8 & 0.0 & 1.4 & 0.0 & 0.0 & 0.0 & 0.0 & 0.0 & 0.0 & 0.0 & 0.0 & 0.0 & 1.1 & 1.8 & 2.6 & 0.0 & .6 & 2.5 & 3.8 \\
\hline LBC(BC) & & Sh & 0 & 0.0 & 0.0 & 0.0 & 0.0 & 0.0 & 0.0 & 1.8 & 0.0 & 1.6 & 0.0 & 0.0 & 0.0 & 0.0 & 0 & .0 & 0.0 & 5 & 0.0 & .0 & .0 & 0 & 2.2 \\
\hline AMS & ELL2 & ltSh & 0.0 & 0.0 & 0.0 & 0.0 & 0.0 & 0.0 & 0.7 & 5.6 & 1.1 & 0.0 & 0.0 & 0.0 & 0.0 & 0.0 & 0.0 & 0.0 & 0.0 & 0.0 & 0.0 & 0.0 & 0.0 & 0.0 & 1.8 \\
\hline AMS & LL3 & Ps & 0 & 0.0 & 0.0 & 0.0 & 0.0 & 0.0 & 0.0 & 5.0 & 1.1 & 0.0 & 0.0 & 2.7 & 0.0 & 0.0 & 0.0 & 0.0 & 0.0 & 0.0 & 0.0 & .0 & .0 & 0.0 & 1.6 \\
\hline AMS & 5 & & 0 & .0 & 0.0 & 0.0 & 0.0 & 0.0 & 0.0 & 2.8 & 3.8 & .0 & 2.8 & 0.0 & 0.0 & 0.7 & 0.0 & .0 & 0.0 & .0 & .0 & .0 & .0 & .0 & 0.0 \\
\hline AMS & 4 & $\mathrm{dkSh}$ & 1 & 0.0 & 0.0 & 0.0 & 1.6 & 0.0 & 0.7 & 5.5 & 0.0 & 0.0 & 0.0 & 0.0 & 0.0 & 0.0 & 0.0 & 0.0 & 1.1 & 0.0 & 1.9 & 2.6 & .1 & 0.0 & 1.9 \\
\hline AMS & EL & & 0 & 0.0 & 0.0 & 3.9 & 3.9 & 0.0 & 0.0 & 0.0 & 0.0 & 0.0 & 0.0 & 0.0 & 0.0 & 0.0 & 0.0 & 0.0 & 3.3 & .0 & 4.6 & 3.6 & .2 & 0.0 & 1.4 \\
\hline CAM(NAD) & $\mathrm{H} 1$ & ltSh & 1.8 & 0.0 & 0.0 & 0.0 & 1.6 & 0.0 & 1.1 & 5.4 & 0.0 & 0.0 & 0.0 & 0.0 & 0.0 & 0.0 & 0.0 & 0.0 & 0.0 & 0.0 & 0.0 & 0.0 & 0.0 & 0.0 & 0.0 \\
\hline CAM(N & AN & $\mathrm{ltSh}$ & 2 & 1.1 & 0.0 & 0.0 & 1.4 & 0.0 & 0.0 & 0.0 & 0.0 & 0.0 & 0.0 & 0.0 & 0.0 & 2.9 & 0.0 & 0.0 & 0.0 & .0 & 0.0 & .0 & .0 & 0.0 & 0.0 \\
\hline CAM(NAD) & АМНЗА & ltSh & .3 & 0.0 & 0.0 & 0.7 & 2.3 & 0.0 & 1.1 & 1.8 & 0.0 & 0.0 & 2.2 & 2.4 & 2.2 & 3.2 & 0.0 & 0.0 & 0.0 & 0.0 & 1.4 & 0.0 & .0 & 0.0 & 0.0 \\
\hline CAM(NAD) & CAN & ltSh & 1.4 & 0.0 & 0.0 & 0.0 & 0.0 & 0.0 & 0.0 & 5.5 & 0.0 & 0.0 & 0.0 & 0.0 & 0.0 & 0.7 & 0.0 & 0.0 & 0.0 & 0.0 & 0.0 & 0.0 & 0.0 & 0.0 & 0.0 \\
\hline AMS & CONC & Ps & 2.1 & 0.0 & 0.0 & 0.0 & 0.0 & 0.0 & 0.0 & 3.4 & 0.7 & 0.0 & 2.2 & 3.1 & 1.9 & 0.0 & 0.0 & 0.0 & 0.0 & .0 & 1.1 & 0.0 & .0 & 0.0 & 0.0 \\
\hline AMS & R1A & $\mathrm{Sh}$ & 0 & 0.0 & 0.0 & 0.0 & 2.3 & 0.0 & 0.0 & 5 & 1.4 & 0.0 & 0.0 & 0.0 & 0.0 & 0.0 & 0 & .2 & 0.7 & .0 & .2 & .4 & .5 & 0 & 1.4 \\
\hline AMS & FAIR1B & d & 0.0 & 0.0 & 0.0 & 0.0 & 3.6 & 0.0 & 0.0 & 3.2 & 0.0 & 0.0 & 0.0 & 0.0 & 0.0 & 0.0 & 0.0 & 0.0 & 1.8 & 0.0 & 2.5 & 5.1 & .5 & 0.0 & 2.2 \\
\hline AMS & FAIR2 & $-\mathrm{dkSh}$ & 0.0 & 0.0 & 0.0 & 0.0 & 1.1 & 0.0 & 0.0 & 4.7 & 0.0 & 0.0 & 0.0 & 0.0 & 0.0 & 0.0 & 0.0 & .0 & 1.9 & .0 & 0.7 & 1.9 & .1 & 0 & L.8 \\
\hline AMS & IR3 & -dkSh & 0.0 & 0.0 & 0.0 & 0.7 & 1.6 & 0.0 & 0.0 & 5.7 & 0.0 & 0.0 & 0.0 & 0.0 & 0.0 & 0.0 & 0.0 & 0.0 & 1.6 & .0 & .7 & .0 & .0 & 0.0 & 1.6 \\
\hline AMS & FAIR4 & $\mathrm{dkSh}$ & 0.0 & 0.0 & 0.0 & 0.0 & 5.3 & 0.0 & 1.8 & 0.0 & 4.3 & 0.0 & 0.0 & 0.0 & 0.0 & 0.0 & 0.0 & 0.0 & 1.4 & 0.0 & 1.1 & 0.0 & .1 & 0.0 & 1.4 \\
\hline AMS & FAIR5 & $\mathrm{kSh}$ & 1.8 & 0.0 & 0.0 & 0.7 & 4.3 & 2.5 & 1.6 & 3. & 4.7 & 0.0 & 0.0 & 0.0 & 1.6 & 0.0 & 0.7 & 0.0 & 0.7 & 0.0 & 2.2 & 0.7 & .8 & 0.0 & 0.7 \\
\hline AMS & GRR5A & s-dkSh & 0.0 & 0.0 & 0.0 & 0.0 & 3.3 & 0.0 & 0.0 & 6.1 & 3.8 & 0.0 & 0.0 & 0.0 & 2.2 & 0.0 & 0.0 & 0.0 & 2.1 & 0.0 & 1.4 & 0.0 & 0.0 & 0.0 & 2.4 \\
\hline AMS & RR5B & dkSh-Ms & 0.0 & 0.0 & 0.0 & 0.0 & 1.4 & 0.0 & 0.0 & 5.5 & 2.6 & 0.0 & 0.0 & 0.0 & 0.0 & 0.0 & 0.0 & 0.0 & 0.0 & 0.0 & 0.0 & .0 & .0 & .0 & 0.0 \\
\hline AMS & RR6A & $\mathrm{dkSh}$ & 0.0 & 0.0 & 0.0 & 0.0 & 4.9 & 0.0 & 1.1 & 1.6 & 4.8 & 0.0 & 0.0 & 0.0 & 0.0 & 0.0 & 0.0 & 0.0 & 2.6 & 0.0 & 2.6 & 0.0 & 0.0 & 0.0 & 2.2 \\
\hline AMS & 6B & kSh & 0.0 & 0.0 & 0.0 & 0.0 & 5.5 & 0.0 & 0.0 & 0.0 & 3.5 & 0.0 & 0.0 & 0.0 & 0.0 & 0.0 & 0.0 & 0.0 & 0.0 & 0.0 & 4.2 & 0.0 & 1.6 & 0.7 & 3.3 \\
\hline AMS & R9A & ltS & & 0.0 & 0.0 & 0.0 & 0.0 & 0.0 & 0.0 & 5.6 & 2.8 & 1.1 & 0.0 & 0.0 & 0.0 & 0.7 & 1.4 & 0.7 & 0.0 & .0 & 0.0 & 0 & .0 & .0 & 0.0 \\
\hline AMS & RR9B & tSh-Ps & 0.0 & 0.0 & 0.0 & 0.0 & 1.1 & 0.0 & 0.0 & 0.0 & 0.0 & 5.6 & 0.7 & 4.0 & 0.7 & 0.0 & 1.9 & 0.0 & 0.0 & .0 & 0.0 & .0 & .0 & 0.0 & 0.0 \\
\hline LBC(BC) & BCH2 & $\mathrm{dkSh}$ & 0.0 & 0.0 & 0.0 & 2.2 & 3.8 & 0.0 & 0.0 & 0.0 & 0.0 & 0.0 & 0.0 & 0.0 & 0.0 & 0.0 & 0.0 & 0.0 & 0.0 & 0.0 & 3.1 & 0.7 & 0.0 & 0.0 & 0.0 \\
\hline LBC(BC) & ЗСН3 & Sh-Ms & 0.0 & 0.0 & 0.0 & 0.0 & 1.4 & 0.0 & 0.0 & 4.7 & 0.0 & 0.0 & 0.0 & 0.0 & 0.0 & 0.0 & 0.0 & 0.0 & 0.0 & 3.1 & 0.0 & 0.0 & .0 & 0.0 & 1.1 \\
\hline LBC(BC) & BCH4 & lt-dkSh & 0.0 & 2.5 & 0.0 & 0.0 & 4.3 & 4.1 & 0.0 & 4.7 & 0.0 & 0.0 & 0.0 & 0.0 & 0.0 & 0.0 & 0.0 & 0.0 & 2.9 & .0 & 1.8 & 0.0 & .0 & 0.0 & 0.0 \\
\hline CAM(NAD) & NAP1 & Ps & 0.0 & 0.0 & 0.0 & 0.0 & 2.1 & 0.0 & 0.0 & 1.6 & 3.6 & 0.0 & 0.0 & 0.0 & 0.0 & 0.0 & 0.0 & 0.0 & 0.0 & 0.0 & 0.0 & 0.0 & 0.0 & 0.0 & 0.0 \\
\hline CAM(NAD) & AP3 & ltSh & 1.4 & 0.0 & 0.0 & 0.0 & 0.0 & 0.0 & 0.0 & 0.0 & 5.2 & 0.0 & 0.0 & 0.0 & 2.6 & 0.0 & 0.0 & 0.0 & 0.0 & 0.0 & 0.0 & 0.0 & 0.0 & 0.0 & 0.0 \\
\hline CAM(NAD) & NAY1 & ltSh & 2.3 & 0.0 & 0.0 & 0.0 & 0.0 & 0.0 & 0.0 & 5.4 & 0.0 & 0.0 & 0.0 & 0.0 & 0.0 & 2.6 & 0.7 & 2.6 & 0.0 & 0.0 & 0.0 & 0.0 & 0.0 & 0.0 & 0.0 \\
\hline CAM(NAD) & AY2A & Ps & 0.0 & 0.0 & 0.0 & 0.0 & 2.6 & 0.0 & 0.0 & 1.6 & 0.0 & 0.0 & 0.0 & 0.0 & 0.0 & 1.4 & 0.0 & 0.0 & 0.0 & 0.0 & 0.0 & 0.0 & 0.0 & 0.0 & 0.0 \\
\hline CAM(NAD) & NAY2B & Ws & 0.0 & 0.0 & 0.0 & 0.0 & 0.0 & 0.0 & 0.0 & 3.5 & 0.0 & 0.0 & 0.0 & 0.0 & 0.0 & 0.0 & 0.0 & 0.0 & 0.0 & 0.0 & 0.0 & 0.0 & 0.7 & 0.0 & 0.0 \\
\hline AMS & NEW1 & kSh-Ms & 2.2 & 0.0 & 0.0 & 2.5 & 2.9 & 0.0 & 0.0 & 5.3 & 0.7 & 0.0 & 0.7 & 0.0 & 0.0 & 1.1 & 0.0 & 3.0 & 0.0 & 0.0 & 2.6 & 3.1 & 0.0 & 0.0 & 0.7 \\
\hline $\mathrm{U}$ & & & 0.0 & 0.0 & 0.7 & 0.0 & 3.3 & 0.0 & 0.0 & 0.0 & 0.0 & 0.0 & 0.0 & 0.0 & 0.0 & 0.0 & 0.0 & 0.0 & 0.0 & 0.0 & 3.4 & 5.0 & 4.2 & 1.4 & 3.4 \\
\hline UBC(PC) & PCP2 & $\mathrm{dkSh}$ & 0.7 & 0.0 & 0.0 & 0.0 & 0.0 & 0.0 & 0.0 & 5.6 & 0.0 & 0.0 & 0.0 & 0.0 & 0.0 & 0.0 & 0.0 & 0.0 & 1.4 & 0.0 & 0.7 & 0.0 & .0 & 0.0 & 1.9 \\
\hline UBC(PC) & РCP3 & $\mathrm{dkSh}$ & 0.7 & 0.0 & 1.1 & 0.0 & 2.6 & 0.0 & 0.0 & 1.8 & 4.2 & 0.0 & 0.0 & 0.0 & 0.7 & 0.0 & 0.0 & 0.0 & 2.1 & 0.0 & 2.9 & 0.0 & 0.0 & 3.6 & 4.4 \\
\hline & & Ps & 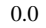 & 0.0 & 0.0 & 0.0 & 0.0 & 0.0 & 0.0 & 2.2 & 1.1 & 0.7 & 0.7 & 0.0 & 0.0 & 0.7 & 0.0 & 0.0 & 0.0 & 0.0 & 0.0 & 0.0 & 0.0 & 0.0 & 0.0 \\
\hline UBC(PC) & PCY2 & $\mathrm{dkSh}$ & 0.0 & 0.0 & 0.0 & 1.6 & 1.4 & 0.0 & 1.1 & 1.9 & 0.0 & 0.0 & 0.0 & 0.0 & 0.0 & 0.0 & 0.0 & 0.0 & 0.0 & 2.3 & 2.7 & 0.0 & 0.0 & 0.0 & 0.7 \\
\hline UBC(PC) & PCY3 & ltSh & 0.0 & 4.9 & 0.7 & 3.0 & 1.6 & 0.0 & 2.2 & 0.0 & 0.0 & 0.0 & 0.0 & 0.0 & 0.0 & 0.0 & 4.5 & 0.0 & 2.1 & 0.0 & 2.8 & 0.7 & 1.9 & 0.0 & 0.0 \\
\hline UBC(PC) & UBCH2 & ltSh & 0.0 & 0.0 & 0.0 & 0.0 & 0.0 & 0.0 & 0.0 & 4.7 & 0.0 & 0.0 & 2.1 & 0.0 & 0.0 & 0.0 & 0.7 & 0.0 & 0.0 & 0.0 & 0.0 & 0.0 & 0.0 & 0.0 & 0.0 \\
\hline
\end{tabular}


Table 3-3: Results of discriminant analysis.

Key to assigned groups: $1=$ Crurithyris Biofacies 2 = Bivalve Biofacies, 3 = Chonetid-Gastropod

Biofacies, and $4=$ Chonetid Biofacies.

Summary of Classification:

\begin{tabular}{cccccc}
\multicolumn{6}{c}{ True Group } \\
\hline Assigned Group & 1 & 2 & 3 & 4 \\
1 & 7 & 0 & 0 & 0 & \\
2 & 0 & 14 & 0 & 0 & \\
3 & 0 & 0 & 12 & 0 & \\
4 & 0 & 0 & 0 & 25 & \\
& & & & \\
Total N & 7 & 14 & 12 & 25 \\
N correct & 7 & 14 & 12 & 25 \\
Proportion & 1.000 & 1.000 & 1.000 & 1.000 \\
$\mathrm{~N}=58$, N Correct = 58, Proportion Correct $=1.000$ \\
\hline
\end{tabular}

Summary of Classification with Cross-validation:

\begin{tabular}{cccccc}
\multicolumn{7}{c}{ True Group } \\
\hline Assigned Group & 1 & 2 & 3 & 4 & \\
1 & 7 & 0 & 0 & 0 & \\
2 & 0 & 14 & 0 & 0 & \\
3 & 0 & 0 & 12 & 0 & \\
4 & 0 & 0 & 0 & 25 & \\
& & & & & \\
Total N & 7 & 14 & 12 & 25 & \\
N correct & 7 & 14 & 12 & 25 & \\
Proportion & 1.000 & 1.000 & 1.000 & 1.000 \\
$\mathrm{~N}=58$, N Correct = 58, Proportion Correct $=1.000$ \\
\hline
\end{tabular}


Table 3-4: Stratigraphic distribution of biofacies in the four Glenshaw marine zones.

\begin{tabular}{ccccc}
\hline & Chonetid Biofacies & $\begin{array}{c}\text { Chonetid-gastropod } \\
\text { Biofacies }\end{array}$ & Bivalve Biofacies & $\begin{array}{c}\text { Crurithyris } \\
\text { Biofacies }\end{array}$ \\
\hline Ames & $\mathrm{X}$ & $\mathrm{X}$ & $\mathrm{X}$ & $\mathrm{X}$ \\
Cambridge (Nadine) & $\mathrm{X}$ & $\mathrm{X}$ & $\mathrm{X}$ \\
$\begin{array}{c}\text { Upper Brush Creek } \\
\text { (Pine Creek) }\end{array}$ & $\mathrm{X}$ & $\mathrm{X}$ & $\mathrm{X}$ \\
$\begin{array}{c}\text { Lower Brush Creek } \\
\text { (Brush Creek) }\end{array}$ & $\mathrm{X}$ & & \\
\hline
\end{tabular}


Table 3-5: Pair-wise comparison of Mahalanobis distances between biofacies means.

The probability that these distances are no different from random is given in parenthesis.

\begin{tabular}{|c|c|c|c|c|}
\hline & Bivalve & Chonetid-gastropod & Chonetid & Crurithyris \\
\hline Bivalve & $0(1.0)$ & & & \\
\hline Chonetid-gastropod & $129.47(<0.0001)$ & $0(1.0)$ & & \\
\hline Chonetid & $89.21(<0.0001)$ & $62.44(<0.0001)$ & $0(1.0)$ & \\
\hline Crurithyris & $46.83(<0.0001)$ & $164.47(<0.0001)$ & $55.88(<0.0001)$ & $0(1.0)$ \\
\hline
\end{tabular}

$p<0.05$; distance between biofacies pairs is greater than random. 
Table 3-6: MANOVA test of differences between biofacies means.

\begin{tabular}{lrc}
\hline & \multicolumn{1}{c}{$\mathrm{F}$} & $\mathrm{Pr}>\mathrm{F}$ \\
\hline Wilks' Lambda & 10.12 & $<0.0001$ \\
Pillai's Trace & 6.12 & $<0.0001$ \\
Hotelling-Lawley Trace & 14.25 & $<0.0001$ \\
Roy's Greatest Root & 29.52 & $<0.0001$ \\
\hline$p<0.05$; biofacies means are significantly different.
\end{tabular}


Table 3-7: Univariate tests results for random distribution of taxa among the four biofacies. Nonrandomly distributed taxa are highlighted in bold type. Taxa are listed in order of decreasing abundance to illustrate a possible relationship between abundance and distribution (see text for explanation).

\begin{tabular}{lrr}
\hline & $\mathrm{F}$ & \multicolumn{1}{c}{$\operatorname{Pr}>\mathrm{F}$} \\
\hline Chonetids & 22.50 & $<\mathbf{0 . 0 0 0 1}$ \\
Crurithyris & 20.49 & $<\mathbf{0 . 0 0 0 1}$ \\
Nuculopsis & 26.15 & $<\mathbf{0 . 0 0 0 1}$ \\
Donaldina & 13.90 & $<\mathbf{0 . 0 0 0 1}$ \\
Euphemites & 35.35 & $<\mathbf{0 . 0 0 0 1}$ \\
Glabrocingulum & 10.42 & $<\mathbf{0 . 0 0 0 1}$ \\
Girtyspira & 9.00 & $<\mathbf{0 . 0 0 0 1}$ \\
Knightites & 9.53 & $<\mathbf{0 . 0 0 0 1}$ \\
Linoproductus & 0.41 & 0.7487 \\
Dunbarella & 0.83 & 0.4833 \\
Edmondia & 4.28 & $\mathbf{0 . 0 0 8 8}$ \\
Pharkidonotus & 1.62 & 0.1966 \\
Aviculopectin & 1.29 & 0.2887 \\
Paleyoldia & 3.15 & $\mathbf{0 . 0 3 2 2}$ \\
Phestia & 6.74 & $\mathbf{0 . 0 0 0 6}$ \\
Juresania & 2.23 & 0.0956 \\
Astartella & 2.69 & 0.0554 \\
Meekospira & 2.81 & $\mathbf{0 . 0 4 8 2}$ \\
Derbyia & 0.75 & 0.529 \\
Cancrinella & 0.86 & 0.4668 \\
Neospirifer & 2.23 & 0.0957 \\
Antiquatonia & 1.42 & 0.2473 \\
Composita & 1.03 & 0.3858 \\
\hline P & $15.05 ;$ taxa &
\end{tabular}

$p<0.05$; taxa are non-randomly distributed among biofacies. 


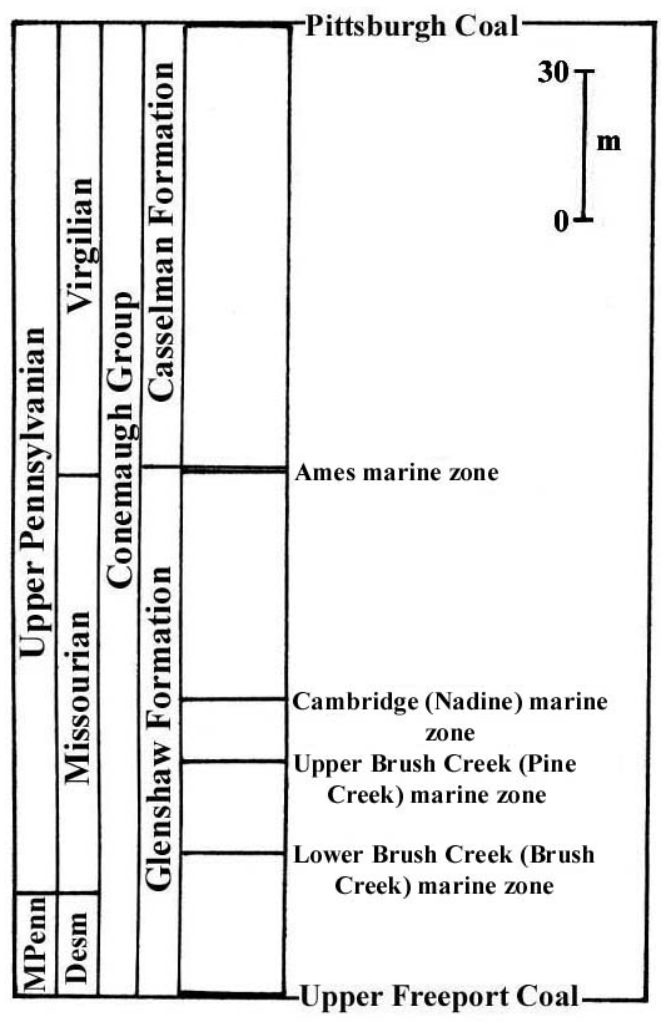

Figure 3-1. Generalized stratigraphic column of the Conemaugh Group with the position of the four major Glenshaw marine zones sampled in this study (modified from Edmunds et al., 1999). 


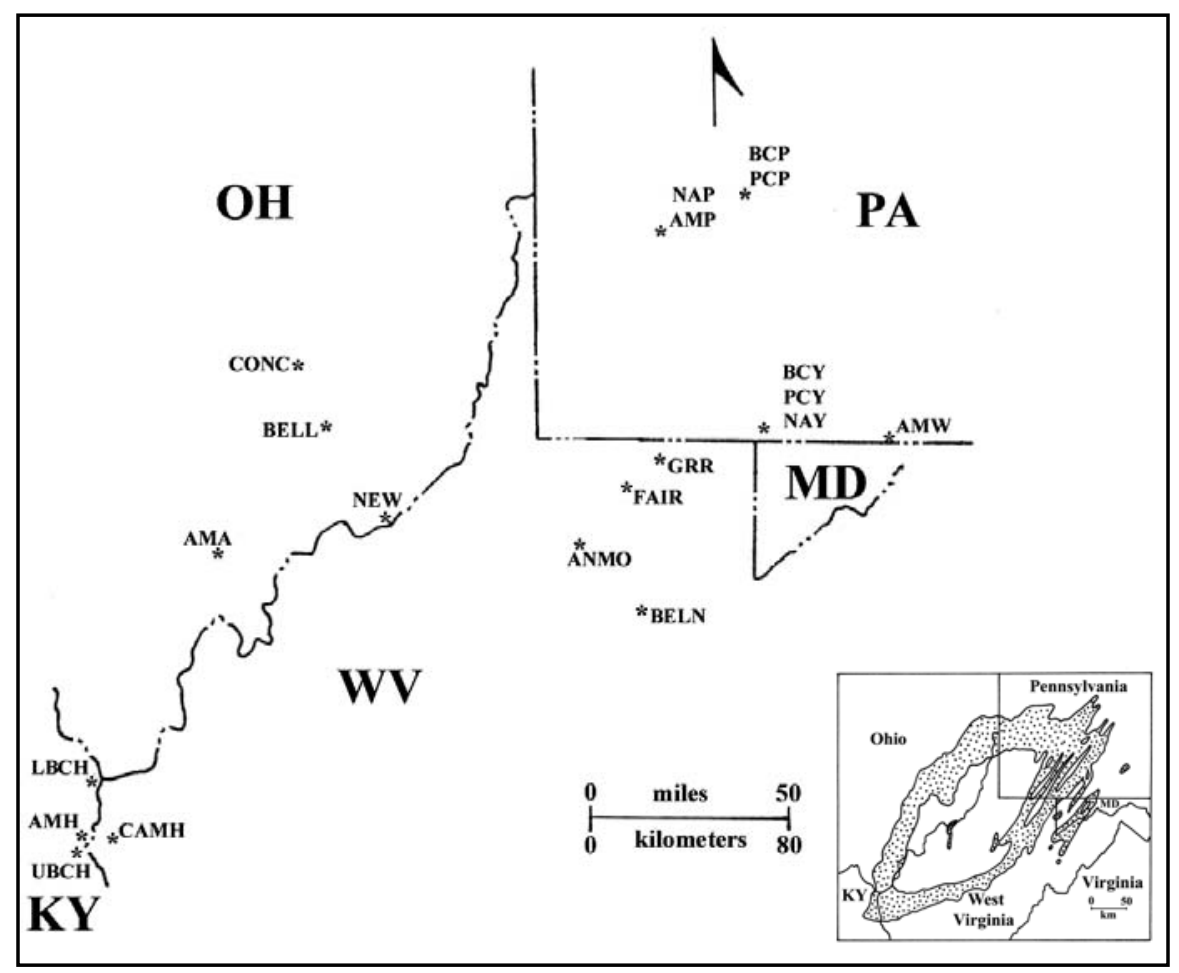

Figure 3-2. Map showing the locations of sampled Glenshaw marine zones within their respective geographic area in the northern Appalachian Basin. Refer to Table 3-1 for outcrop abbreviations. Inset picture shows the distribution of the Conemaugh Group in the Appalachian Basin. Data compiled from state geologic maps. 


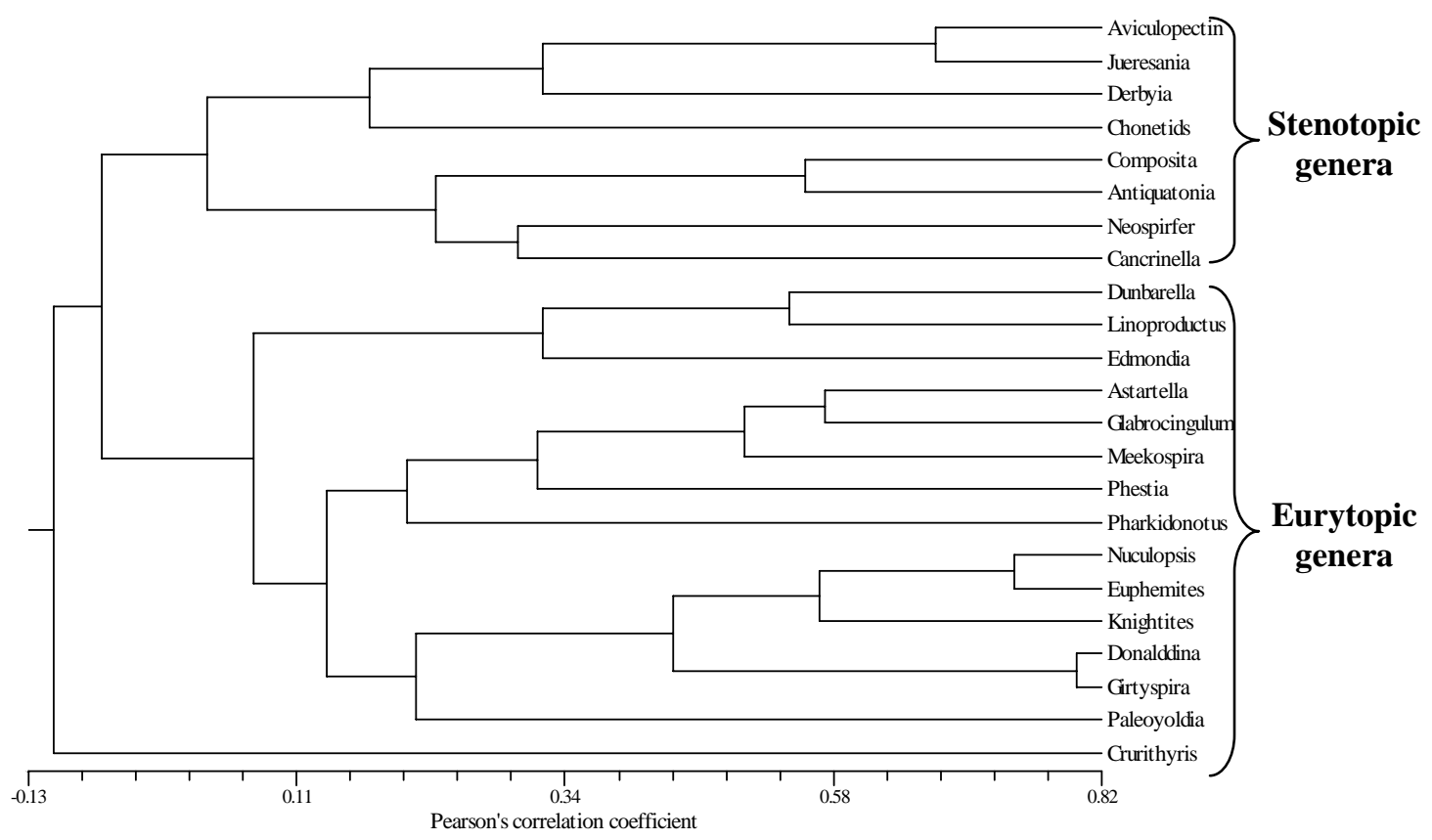

Figure 3-3. R-mode cluster diagram of the natural log transformed data of the ten most abundant brachiopod, bivalve, and gastropod genera in the four Glenshaw marine zones in this study. The resulting tree separates stenotopic brachiopods and one bivalve from eurytopic gastropods, bivalves, and the brachiopod Linoproductus. The brachiopod Crurithyris comprises its own branch reflecting its unique distribution within Glenshaw marine zones. 


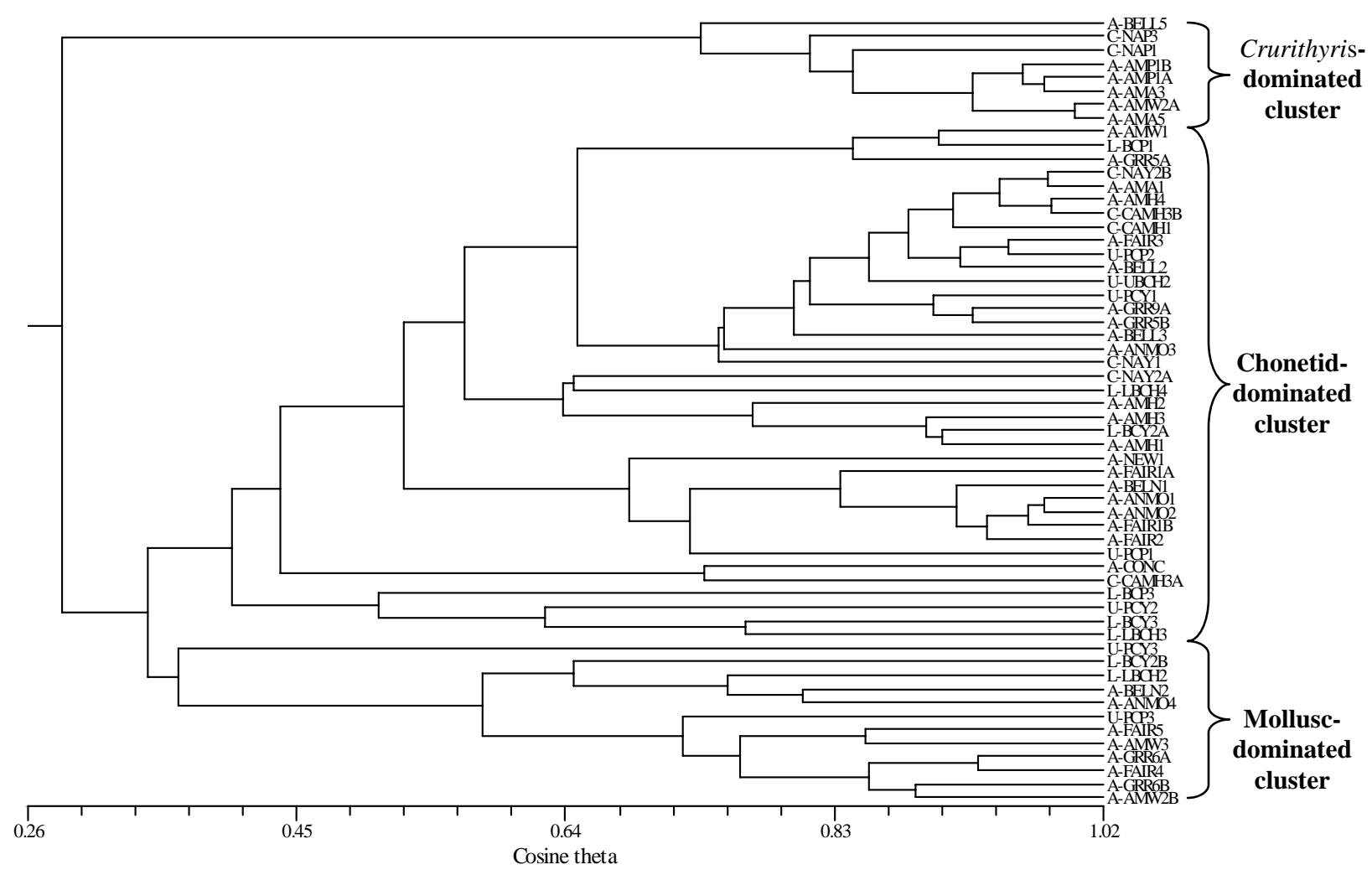

Figure 3-4. Q-mode cluster diagram of the natural log transformed data of the ten most abundant brachiopod, bivalve, and gastropod genera within 58 samples taken from the four Glenshaw marine zones. The resulting tree divides the samples into three clusters: a Crurithyris-dominated cluster, a Chonetid-dominated cluster, and a mollusc-dominated cluster. Marine zones are coded with the prefixes: $\mathrm{L}=$ Lower Brush Creek (Brush Creek); $\mathrm{U}=$ Upper Brush Creek (Pine Creek); C = Cambridge (Nadine); A = Ames. 


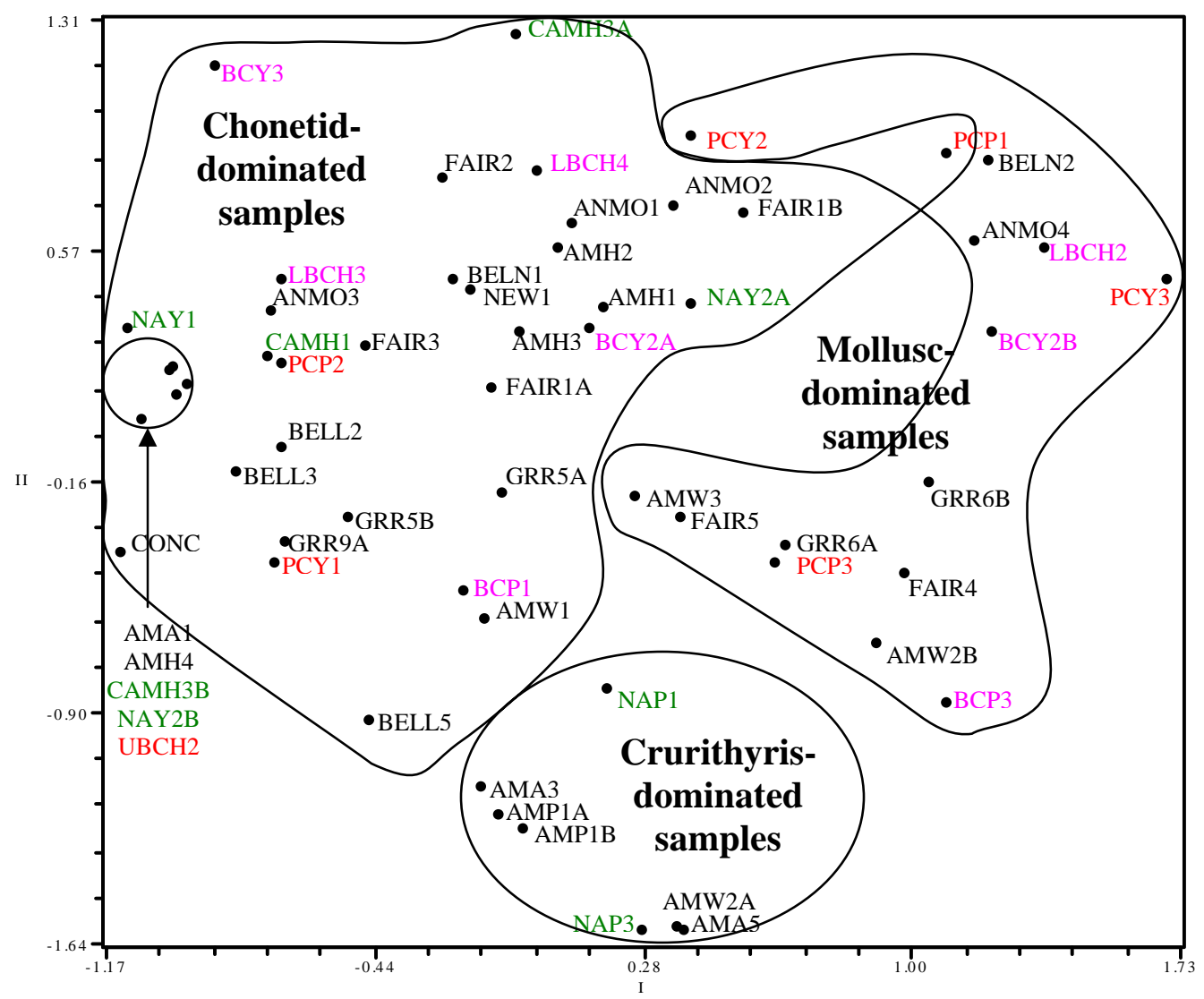

Figure 3-5. Two-dimensional Q-mode MDS plot of the natural log transformed data of the ten most abundant brachiopod, bivalve, and gastropod genera within 58 samples from the four marine zones in the Glenshaw Formation. Final stress $=0.18$, which is good to fair (Rohlf, 1998). Groups of samples identified during cluster analysis (Mollusc, Chonetid, and Crurithyris) are outlined and labeled. Although the results from the cluster analysis and MDS distinguished similar sample groups, the distance between points within a single sample group approached, and in some cases exceeded, the separation of points between sample groups. This suggests that the three groups defined by cluster analysis are not truly discrete, and in particular, the relatively wide spread of samples assigned to the large Chonetid cluster confirmed the observation that many of these samples were grouped at low similarity and that the large Chonetid cluster may be an artifact of the divisive nature of cluster analysis. Glenshaw marine zone are color coded: Lower Brush Creek (Brush Creek $)=$ pink; Upper Brush Creek $($ Pine Creek $)=$ red; Cambridge $($ Nadine $)=$ green; Ames $=$ black. 
Natural $\log$ values

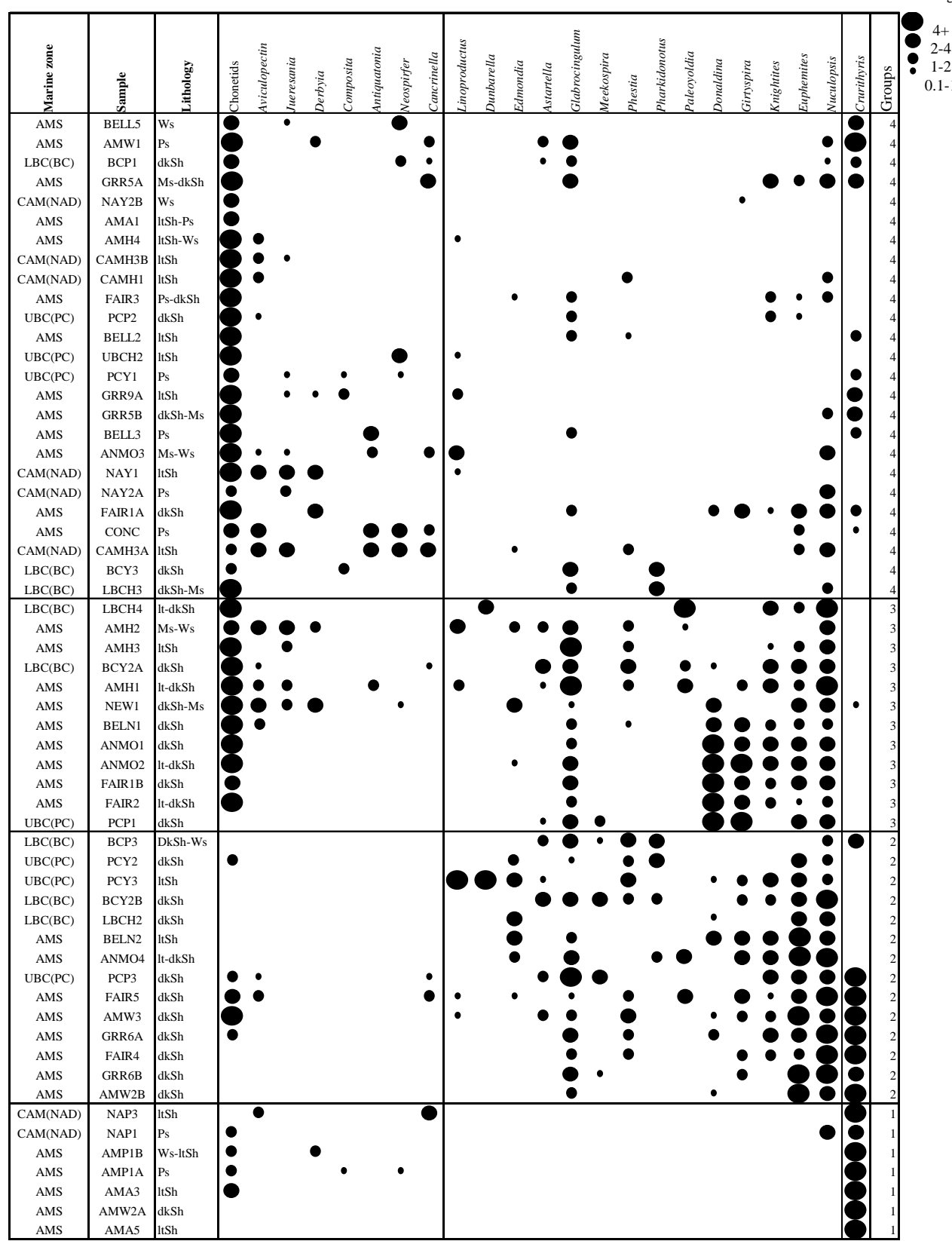

Figure 3-6. Two-way abundance diagram of Glenshaw taxa and samples. Taxa are grouped according to the results of R-mode cluster analysis. Samples are grouped according to the results of discriminant analysis. Note the gradient from the brachiopod Crurithyris and the molluscs in the bottom right-hand corner of the diagram to the stenotopic brachiopods in the upper left-hand corner. Marine zone abbreviations: LBC (BC) = Lower Brush Creek (Brush Creek); UBC (PC) = Upper Brush Creek (Pine Creek); CAM (NAD) = Cambridge (Nadine); AMS = Ames. Lithology abbreviations: Clastics (ltSh-light shale, dkSh-dark shale); Carbonates (Ms-mudstone, Ws-Wackestone, Ps-packstone). 
A.

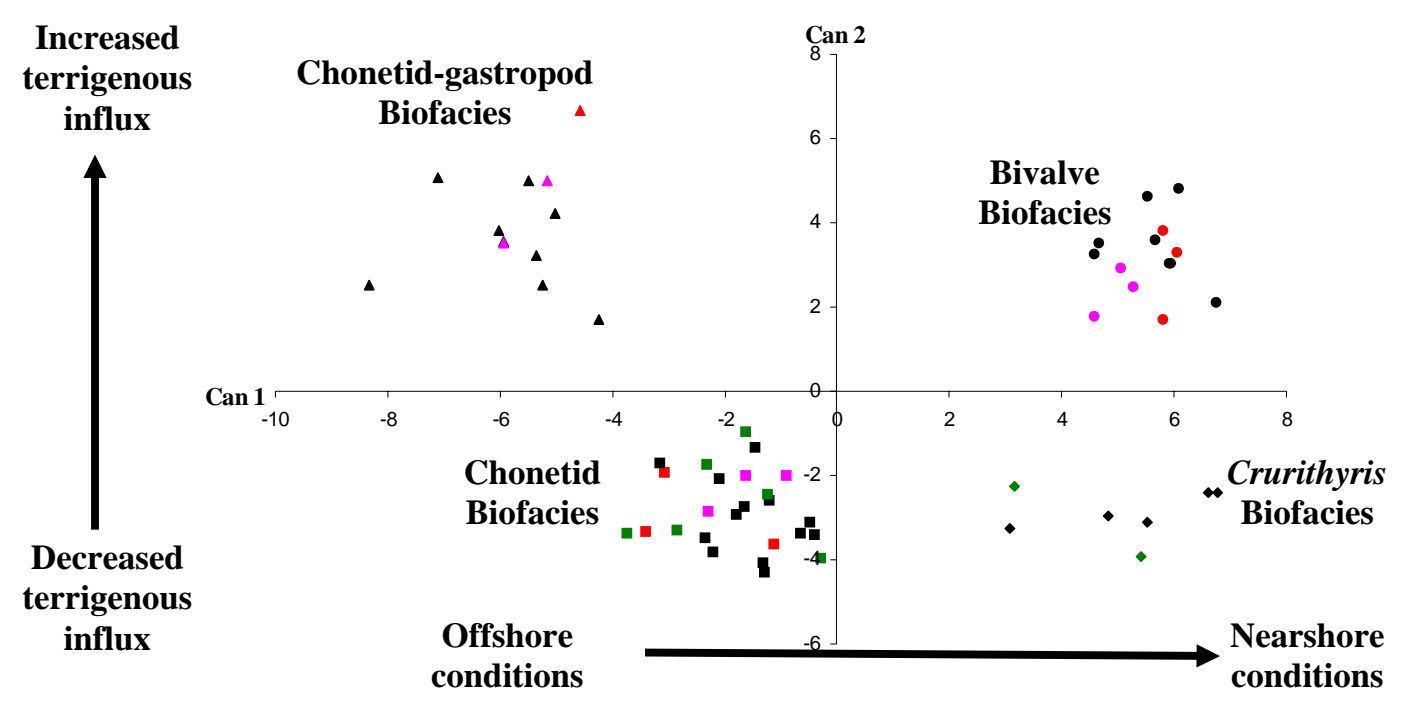

B.

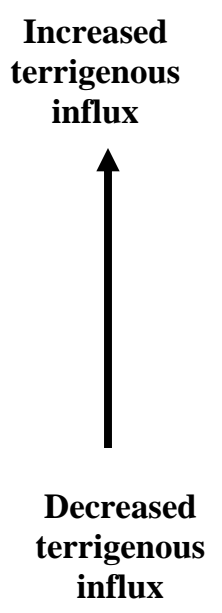

\section{Can 1 vs Can 2}

Can 1 vs Can 2

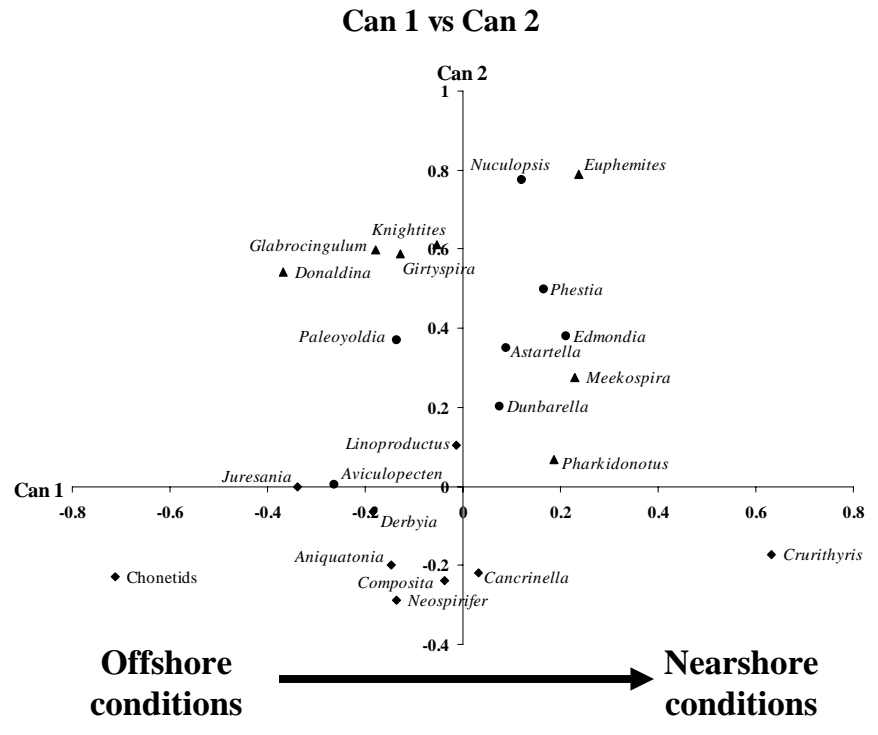

Figure 3-7. Canonical variate analysis (CVA) plots.(A) Plot of sample groups, labeled as biofacies based on a predominant taxa, are well defined and separated in multivariate space. Glenshaw marine zone are color coded: Lower Brush Creek (Brush Creek) = pink; Upper Brush Creek (Pine Creek) = red; Cambridge (Nadine) = green; Ames = black. (B) Plot of the level of correlation of each variable (taxa) to the total canonical structure of the two canonical variables. Gastropods are represented by triangles, bivalves are represented by circles, and brachiopods are represented by diamonds. The arrangement of variables provides a sense of how each individual genus or genera contributes to the arrangement of samples on the CVA plot in Figure 3-7A. 


\section{Observed composite sequence of biofacies in Glenshaw marine zones}

\begin{tabular}{|c|c|}
\hline AMS & $\begin{array}{l}\mathrm{Bi} \text { or } \mathrm{Cr} \\
\quad \mathrm{Ch} \\
\mathrm{Bi} \text { or } \mathrm{Ch}-\mathrm{g} \\
\mathrm{Ch} \text { or Ch-g }\end{array}$ \\
\hline & $\begin{array}{c}\text { Non-marine } \\
\text { Deposits }\end{array}$ \\
\hline $\begin{array}{c}\text { CAM } \\
\text { (NAD) }\end{array}$ & $\begin{array}{l}\mathrm{Cr} \\
\mathrm{Ch} \\
\end{array}$ \\
\hline & $\begin{array}{c}\text { Non-marine } \\
\text { Deposits }\end{array}$ \\
\hline $\begin{array}{l}\mathrm{UBC} \\
(\mathrm{BC})\end{array}$ & $\begin{array}{c}\text { Bi } \\
\text { Ch-g or } \mathrm{Ch}\end{array}$ \\
\hline & $\begin{array}{c}\text { Non-marine } \\
\text { Deposits }\end{array}$ \\
\hline $\begin{array}{l}\mathrm{LBC} \\
(\mathrm{BC}) \\
\end{array}$ & $\begin{array}{c}\mathrm{Bi} \\
\text { Ch-g or Ch } \\
\mathrm{Bi} \\
\end{array}$ \\
\hline
\end{tabular}

Figure 3-8. Composite biofacies sequence within the four marine zones examined in this study. Marine zone abbreviations: LBC (BC) = Lower Brush Creek (Brush Creek); UBC (PC) = Upper Brush Creek (Pine Creek); CAM (NAD) = Cambridge (Nadine); AMS = Ames. Bivalve $(\mathrm{Bi})$ and Crurithyris $(\mathrm{Cr})$ biofacies represent nearshore (high-energy) conditions, Chonetid-gastropod (Ch-g) and Chonetid (Ch) represent offshore (low-energy) conditions. Note the absence of the nearshore biofacies in three of the four marine zones, which is attributed to rapid transgression. 


\section{References}

Aberhan, M., 1994, Guild structure and evolution of Mesozoic benthic shelf communities, Palaios v. 9, p. 516-545.

Ager, D.V., 1965. The adaptation of Mesozoic brachiopods to different environments, Palaeogeography, Palaeoclimatology, Palaeoecology, v. 1, p. 143-172.

Aigen, A.A., 1974, Early Mississippian gastropods of the Burlington Limestone, unpublished M.S. thesis, University of Illinois, Champaign-Urbana, IL, 138 p.

Aller, R.C., and Dodge R.E., 1974, Animal-sediment relations in a tropical lagoon, Discovery Bay, Jamaica, Journal of Marine Research, v. 32, p. 209-232.

Al-Qayim, B.B., 1983. Facies analysis and depositional environments of the Ames marine member (Virgilian) of the Conemaugh Group (Pennsylvanian) in the Appalachian Basin, unpublished Ph.D. dissertation, University of Pittsburgh, Pittsburgh, PA, 306 p.

Anderson, J.R., 1986. Gastropod biostratigraphy and biofacies of the Upper Carboniferous (Pennsylvanian) system in the Appalachian (Dunkard) Basin, unpublished Ph.D. dissertation, University of Pittsburgh, Pittsburgh, PA, 340 p.

Arkle, T. Jr., 1974, Stratigraphy of the Pennsylvanian and Permian Systems of the central Appalachians, in Briggs, G., editors, Carboniferous of the Southeastern United States:

Geological Society of America Special Paper 148, p.153-170.

Bambach, R.K., 1983, Ecospace utilization and guilds in marine communities through the Phanerozoic, in Tevesz, M.J.S., and McCall, P.L., editors., Biotic Interactions in Recent and Fossil Communities, Plenum Press, p. 719-746.

Bambach, R.K., 1994, The null hypothesis for community stability and recurrenceEnvironmental selection of adapted organisms, Geological Society of America Annual Meeting Abstracts with Programs, v. 26, p. A519.

Bennington, J.B., 1995. Community persistence and the pattern of community variability over time: A test using fossil assemblages from four marine transgressions in the Breathitt Formation (Middle Pennsylvanian) of eastern Kentucky, unpublished Ph.D. dissertation, Virginia Polytechnic Institute, Blacksburg, VA. 410 p.

Bennington, J.B., 1996, Stratigraphic and biofacies patterns in the Middle Pennsylvanian Magoffin marine unit in the Appalachian Basin, U.S.A., International Journal of Coal Geology v. 31, p. 169-193.

Bennington, J.B., 2002. Eustacy in cyclothems is masked by loss of marine biofacies with increasing proximity to a detrital source: an example from the central Appalachian Basin, U. S. A., in Hills, L.V., Henderson, C.M., Bamber, E.W., eds., Carboniferous and Permian of the 
World. Canadian Society of Petroleum Geologists, Memoir 19, p.12-21.

Bennington, J.B., and Bambach, R.K., 1996, Statistical testing for paleocommunity recurrence: Are similar fossil assemblages ever the same?, Palaeogeography, Palaeoclimatology, and Palaeoecology, v. 127, p. 47-81.

Bianchi, C.N., And Morri, C., 1996, Ficopomatus "reefs" in the Po river delta (Northern Adriatic): their constructional dynamics, biology, and influence of the brackish-water biota, Marine Ecology Pubblicazioni della Stazione Zoologica di Napoli, v. 17, p. 51-66.

Boardman, D.R. II, Mapes, R.H., Yancey, T.E., and Malinky, J.M., 1984, A new model for the depth related allogenic community succession within North American Pennsylvanian cyclothems and implications on the black shale problem, in Hyne, N.J., ed., Limestones of the Midcontinent, Tulsa Geologic Society Special Publication 2, p.141-182.

Boardman, R.S. and Cheetham, A.H., 1987, Phylum Bryozoa, in Boardman R.S., Cheetham, A H., and Rowell, A.J., eds., Fossil Invertebrates. Blackwell Scientific Publications, p. 397-449.

Bonuso, N., Newton, C.R., Brower, J.C., Ivany, L.C., 2002a, Statistical testing of community patterns: uppermost Hamilton Group, Middle Devonian (New York State: USA), Palaeogeography, Palaeoclimatology, and Palaeoecology, v. 185, p. 1-24.

Bonuso, N., Newton, C.R., Brower, J.C., Ivany, L.C., 2002b, Does coordinated stasis yield taxonomic and ecologic stability?: Middle Devonian Hamilton Group of central New York, Geology, v. 30, p. 1055-1058.

Brenchley, P.J. and Harper, D.A.T., 1998. Chapter 7: Populations and Communities, in Palaeoecology: Ecosystems, Environments and Evolution. Chapman and Hall, p. 218-270.

Brett, C.E., 1998, Sequence stratigraphy, paleoecology, and evolution: Biotic clues and responses to sea-level fluctuations, Palaios, v. 13, p. 241-262.

Brett, C.E., and Baird, G.C., 1986, Comparative Taphonomy: a key to environmental interpretation based on fossil preservation, Palaios, v. 1, p. 207-227.

Brett, C.E., Miller, K.B., and Baird, G.C., 1990, A temporal hierarchy of paleoecologic processes within a Middle Devonian epieric sea, in Miller, W III, ed., Paleocommunity temporal dynamics: The Long-Term Development of Multispecies Assemblages, Paleontological Society of America Special Publication 5, p. 178-209.

Brett, C.E., and Baird, G.C., 1995, Coordinated Stasis and evolutionary ecology of Silurian to Middle Devonian faunas in the Appalachian Basin, in Erwin, E.H., and Anstey, R.L., eds, New Approaches to Speciation in the Fossil Record, Columbia University Press, p. 285-315.

Brezinski, D.K., 1983, Developmental model for an Appalachian marine incursion, Northeastern Geology, v. 5, p. 92-99. 
Busch, R.M., 1984, Stratigraphic analysis of Pennsylvanian rocks using a hierarchy of transgressive-regressive units, unpublished Ph.D. dissertation, University of Pittsburgh, Pittsburgh, PA, 427 p.

Busch, R.M. and Rollins, H.B., 1984, Correlation of Carboniferous stratigraphy using a hierarchy of transgressive-regressive units, Geology, v. 12, p. 471-474.

Busch, R.M. and West, R.R., 1987, Hierarchical genetic stratigraphy: a framework for paleoceanography, Paleoceanography, v. 2, p. 141-164.

Cant, D.J., 1982, Fluvial facies models and their application, in Scholle, P.A., and Spearing, D., eds., Sandstone Depositional Environments, American Association of Petroleum Geologists, 31, p.115-137.

Cecil, C.B., 1990, Paleoclimate controls on stratigraphic repetition of chemical and siliciclastic rocks, Geology, v. 18, p. 533-536.

Cherns, L., Rohr, D.M., and Fryda, J., 2004, Polyplacophoran and symmetrical univalve mollusks, in Webby, B.D., Paris, F., Droser, M.L., and Percival, I.G., eds., The Great Ordovician Biodiversification Event, Macquarie University, Centre for Ecostratigraphy and Paleobiology, p. 179-183.

Cocito, S., Novosel, M., Novosel, A., 2004, Carbonate bioformations around underwater fresh springs in the north-eastern Adriatic Sea, Facies, v. 50, p. 13-17.

Coleman, J.M., and Prior, D.B., 1982, Deltaic environments, in Scholle, P.A. and Spearing, D., eds., Sandstone Depositional Environments, American Association of Petroleum Geologists, 31, p.139-178.

Cox, L.R., 1960, Gastropoda, in Moore, R.C., eds., Treatise on Invertebrate Paleontology, (I) Mollusca 1. Geological Society of America and University of Kansas Press, p. I85-I331.

Crowell, J.C., 1999, Pre-Mesozoic Ice Ages: Their Bearing on Understanding the Climate System, Geological Society of America, Memoir 192, 106 p.

Davis, J.C., 1986, Statistics and Data Analysis in Geology. John Wiley and Sons, 646 p.

Demaison, G.J., and Moore, G.T., 1980, Anoxic environments and oil source bed genesis, American Association of Petroleum Geologists Bulletin 64, p.1179-1209.

Dennison, J.M., and Hay, W.W., 1967, Estimating the needed sample area for subaquatic ecologic studies, Journal of Paleontology, v. 41, p. 706-708.

Denton, G.H., and Hughes, T.J., 1983, Milankovitch theory of ice ages: hypothesis of ice sheet linkage between regional insolation and global climate, Quaternary Research, v. 20, p. 125-144. 
Dickson, P.A., 1974, Some studies of certain Bivalvia in the Pennsylvanian of the Mazon Creek are with emphasis on paleoecology, unpublished M.S. thesis, University of Manchester, Manchester, U. K., 59 p.

Dodd, J.R., and Stanton, Jr., R.J., 1990, Paleoecology, Concepts and Application, John Wiley \& Sons, $502 \mathrm{p}$.

Donahue, J., and Rollins, H.B., 1974, Paleoecological anatomy of a Conemaugh (Pennsylvanian) marine event, in Briggs, G., ed., Carboniferous of the Southeastern United States, Geological Society of America Special Paper 148, p. 153-170.

Droser, M.L., Bottjer, D.J., and Sheehan, P.M., 1997, Evaluating the ecological architecture of major events in the Phanerozoic history of marine invertebrate life, Geology, v. 25, p. 167-170.

Eager, R.M.C., and Pierce, H.W., 1993, A non-marine pelecypod assemblage in the Pennsylvanian of Arizona and its correlation with a horizon in Pennsylvania, Journal of Paleontology, v. 67, p. 61-70.

Edmunds, W.E., Skema, V.W., and Flint, N.K., 1999, Pennsylvanian, in Schultz, C. H., ed., The Geology of Pennsylvania, Pennsylvania Geologic Survey and Pittsburgh Geological Society Special Publication Number 1, 888 p.

Elias, R. J., and Young, G.A., 1998, Coral diversity, ecology, and provincial structure during a time of crisis: The Latest Ordovician to Earliest Silurian Edgewood Province in Laurentia, Palaios, v. 13, p. 98-112.

Flint, N.K., 1965, Geology and mineral resources of southern Somerset County, Pennsylvania, Pennsylvania Geological Survey, Bulletin C56A, 167 p.

Fraiser, M.L., and Bottjer, D.J., 2004, The non-actualistic Early Triassic gastropod fauna: A case study from the Lower Triassic Sinbad Limestone Member, Palaios, v. 19, p. 259-275.

Fürsich, F.T., 1978, The influence of faunal condensation and mixing on the preservation of fossil benthic communities, Lethaia, v. 11, p. 243-250.

Gauch, H.G. Jr., 1982, Multivariate Analysis in Community Ecology, Cambridge University Press, 298 p.

Gilinski, N.L., and Bennington, J.B., 1994, Estimating numbers of whole individuals from collections of body parts: a taphonomic limitation of the paleontological record, Paleobiology, $\mathrm{v}$. 20, p. 245-258.

Gleason, H.A., 1926, The individualistic concept of the plant association, Torrey Botanical Club Bulletin 53, p. 7-26.

Grant, R.E., 1966. Spine arrangement and life habits of the productid brachiopod 
Waagonoconcha, Journal of Paleontology, v. 40, p.1063-1069.

Hallam, A., 1965, Environmental causes of stunting in living and fossil benthonic invertebrates, Palaeontology, v. 8, p. 132-155.

Hallock, P., 1987, Fluctuations in the trophic resource continuum: a factor in global diversity cycles?, Paleoceanography, v. 2, p. 457-471.

Harper, J.A., and Rollins, H.B., 1985, Infaunal or semi-infaunal bellerophont gastropods:

analysis of Euphemites and functionally related taxa, Lethaia v. 18, p. 21-39.

Heckel, P.H., 1977, Origin of phosphatic black shale facies in Pennsylvanian cyclothems of Midcontinent North America, American Association of Petroleum Geologists Bulletin 61, p. 1045-1068.

Heckel, P. H., 1984, Factors in mid-continent Pennsylvanian limestone deposition: in Hyne, N.J., ed., Limestones of the Midcontinent, Tulsa Geologic Society Special Publication 2, p.25-50.

Heckel, P.H., 1986, Sea-level curve for Pennsylvanian eustatic marine transgressive-regressive depositional cycles along midcontinent outcrop belt, North America, Geology v. 14, p. 330-334.

Heckel, P.H., 1991, Thin widespread Pennsylvanian black shales of Midcontinent North America: a record of a cyclic succession of pycnoclines in a fluctuating epieric sea, in Tyson, R.V., and Pearson, T.H., eds., Modern and Ancient Continental Shelf Anoxia. Geological Society of London Special Publication 58, p. 259-273.

Heckel, P.H., 1994, Evaluation of evidence for glacio-eustatic control over marine cyclothems in North America and consideration of possible tectonic effects, in Dennison, J.M. and Ettensohn, F.R., eds., Tectonic and Eustatic Controls on Sedimentary Cycles, Society of Economic Petrologists and Minerologists-Concepts in Sedimentology and Paleontology 4, p. 65-87.

Heckel, P.H., 1995, Glacial-eustatic base level--Climatic model for Late Middle to Late Pennsylvanian coal bed formation in the Appalachian Basin, Journal of Sedimentary Research v. B65, p. 348-356.

Heckel, P.H., 2002, Observations and constraints on radiometric dating of the Pennsylvanian succession in North America and its correlation with dates from Europe, Newsletter on Carboniferous Stratigraphy v. 20, p. 10-14.

Heckel, P.H., Gibling, M.R., and King, N.R., 1998, Stratigraphic model for glacial-eustatic Pennsylvanian cyclothems in highstand nearshore detrital regimes, Journal of Geology, v. 106, p. 373-383.

Hoare, R.D. and Miller, B.B., 1996a, Phylum Mollusca, Class Pelecypoda, in Feldmann, R.M. and Hackathorn, M., eds., Ohio Fossils, Geological Survey of Ohio Bulletin 70, p. 136-141. 
Hoare, R.D. and Miller, B.B., 1996b, Phylum Mollusca, Class Gastropoda, in Feldmann, R.M. and Hackathorn, M., eds., Ohio Fossils, Geological Survey of Ohio Bulletin 70, p. 151-156.

Hoare, R.D., Sturgeon, M.T., and Kindt, E.A., 1979, Pennsylvanian marine Bivalvia and Rostroconchia of Ohio, Ohio Geological Survey Bulletin 67, 77 p.

Hoare, R.D., Sturgeon, M.T., and Anderson Jr., J.R., 1997, Pennsylvanian marine gastropods from the Appalachian Basin, Journal of Paleontology v. 71, p.1019-1039.

Holland, S.M., Miller, A.I., Meyer, D.L., Datillo, B.F, 2001, The detection and importance of subtle biofacies within a single lithofacies: the Upper Ordovician Kope Formation of the Cincinnati, Ohio region, Palaios, v. 16, p. 205-217.

Holland, S. M., and Patzkowski, M.E., 2004, Ecosystem structure and stability: Middle Upper Ordovician of central Kentucky, USA, Palaios, v.19, p. 316-331.

Holterhoff, P.F., 1996, Crinoid biofacies in Upper Carboniferous cyclothems, midcontinent North America: faunal tracking and the role of regional processes in biofacies recurrence, Palaeogeography, Palaeoclimatology, Palaeoecology, v. 127, p. 107-133.

Imbrie, W.S., 1985, A theoretical framework for the Pleistocene ice ages, Journal of the Geological Society of London, v. 142, p. 417-432.

Ivany, L.C., 1996, Coordinated stasis or coordinated turnover? Exploring intrinsic vs. extrinsic controls on pattern, Palaeogeography, Palaeoclimatology, and Palaeoecology, v. 127, p. 239256.

Jablonski, D., 1985, Molluscan Development, in Broadhead, T.W., ed., Mollusks: notes for a short course, Orlando, Florida, October 27, 1985, University of Tennessee Department of Geological Sciences Studies in Geology 13, p. 33-49.

Jacobs, S.E., 1976, Neochonetes granulifer, an explosive opportunist from the Stull Shale (Upper Pennsylvanian) in southwestern Iowa, The Proceedings of the Iowa Academy of Science, v. 83, p. 20-22.

Joeckel, R.M., 1995, Paleosols below the Ames marine unit (Upper Pennsylvanian, Conemaugh Group) in the Appalachian Basin, U.S.A.: variability on an ancient depositional landscape, Journal of Sedimentary Research, v. A65, p. 393-407.

Johnson, R.G., 1962, Interspecific association in Pennsylvanian fossil assemblages, Journal of Geology, v. 70, p. 32-55.

Joreskog, K.G., Klovan, J.E., and Reyment, R.A., 1976, Geological Factor Analysis. Elsevier Publishing Company, Amsterdam, 178 p.

Jorgensen, C.B., 1966, Biology of Suspension Feeding. Pergamon Press, 357 p. 
Kammer, T.W., Brett, C.E., Boardman, D.R. II, and Mapes, R.H., 1986, Ecologic stability of the dysaerobic biofacies during the Late Paleozoic: Lethaia, v. 19, p. 109-121.

Kammer, T.W. and Lake, A.M., 2001, Salinity ranges of Late Mississippian invertebrates of the central Appalachian Basin, Southeastern Geology, v. 40, p. 99-116.

Kidder, D.L., 1985, Petrology and origin of phosphate nodules from the midcontinent Pennsylvanian epicontinental sea, Journal of Sedimentary Petrology, v. 55, p. 809-816.

Kidwell, S.M., and Bosence, D.W.J., 1991, Taphonomy and time averaging of marine shelly faunas: in Allison, P.A., and Briggs, D.E.G., eds., Taphonomy: Releasing the Data in the Fossil Record, Plenum Press, p.115-209.

Kidwell, S.M., and Flessa, K.W., 1995, The quality of the fossil record: populations species, and communities, Annual Review of Ecology and Systematics, v. 26, p. 269-299.

Lamborn, R.E., 1951, Limestones of eastern Ohio, Ohio Geological Survey Bulletin 49, 377 p.

Lane, H.R., Merrill, G.K., Straka, J.J.II, and Webster, G.D., 1971, Pennsylvanian conodont biostratigraphy: in Sweet, W.C., and Bergström, S.M., eds., Symposium on Conodont Biostratigraphy, Geological Society of America Memoir 127, p. 395-414.

Lebold, J.G. (this volume) - Chapter 2: Degree of environmental stability as a primary control on biotic distribution: Gradient analysis of four marine zones within the Glenshaw Formation (Conemaugh Group, Upper Pennsylvanian) in the Appalachian Basin.

Lebold, J.G., and Kammer, T.W., (this volume) - submitted, Gradient analysis of faunal distributions associated with rapid transgression and low accommodation space in a Late Pennsylvanian marine embayment: Biofacies of the Ames Member (Glenshaw Formation, Conemaugh Group) in the northern Appalachian Basin, U.S.A. Submitted to Palaeogeography, Palaeoclimatology, Palaeoecology.

Leighton, L.R., 2000, Environmental distribution of spinose brachiopods from the Devonian of New York: Test of the soft-substrate hypothesis, Palaios, v. 15, p. 184-193.

Levinton, J. S., 1970, The paleoecological significance of opportunistic species, Lethaia, v. 3, p. 69-78.

Lintz, J. Jr., 1958, The fauna of the Ames and Brush Creek shales of the Conemaugh Formation of western Maryland, Journal of Paleontology, v. 32, p. 97-112.

Malinky, J.M., and Heckel, P.H., 1998, Paleoecology and taphonomy of faunal assemblages in gray "core"(offshore) shales in midcontinent Pennsylvanian cyclothems, Palaios, v. 13, p. 311334.

Mancini, E.A., 1978, Origin of micromorph faunas in the geologic record, Journal of 
Paleontology, v. 52, p. 311-322.

Maples, C.G., 1986, Enhanced paleoecological and paleoenvironmental interpretations result from analysis of early diagenetic concretions in Pennsylvanian shales, Palaios v. 1, p. 512-516.

Martino, R.L., 2004, Sequence stratigraphy of the Glenshaw Formation (Middle-Late Pennsylvanian) in the central Appalachian Basin, in Pashin, J.C., and Gastaldo, R.A., eds., Sequence Stratigraphy, Paleoclimate, and Tectonics of Coal-bearing Strata, American Association of Petroleum Geologists Studies in Geology 51, p.1-28.

Martino, R.L., McCullough, M.A., and Hamrick, T.L., 1996, Stratigraphic and depositional framework of the Glenshaw Formation (Late Pennsylvanian) in central Wayne County, West Virginia, Southeastern Geology, v. 36, p. 65-83.

McKinney, M.L., Lockwood, J.L., Fredrick, D.R., 1996, Does ecosystem stability include rare species?, Palaeogeography, Palaeoclimatology, Palaeoecology, v. 127, p. 191-207.

Merrill, G. K., 1973, Pennsylvanian conodont paleoecology, Geological Society of America Special Paper, v. 141, p. 239-244.

Merrill, G. K., 1986, Lithostratigraphy and lithogenesis of Conemaugh (Carboniferous) depositional systems near Huntington, West Virginia: Southeastern Geology, v. 28, p. 155-171.

Merrill, G.K., 1988, Marine transgression and syndepositional tectonics; Ames Member (Glenshaw Formation, Conemaugh Group, Upper Carboniferous) near Huntington, West Virginia, Southeastern Geology, v. 28, p. 153-166.

Merrill, G.K., 1993, Late Carboniferous paleoecology along a tectonically active basin margin: Ames Member near Huntington, West Virginia, Southeastern Geology, v.33, p. 111-129. Miller, W, III, 1986, Paleoecology of benthic community replacement, Lethaia, v.19, p. 225-231.

Miller, W, III, 1993, Models of recurrent fossil assemblages, Lethaia, v. 26, p. 182-183.

Minitab Inc., 2003, MINITAB Statistical Software, Release 14 for Windows. State College, Pennsylvania.

Morris, P.J., Ivany, L.C., Schopf, K.M., and Brett, C.E., 1995, The challenge of paleoecological stasis: reassessing sources of ecological stability, Proceedings of the National Academy of Science, USA, v. 92, p. 11, 269-11,273.

Nadon, G.C., and Kelley, R.R., 2004, The constraints of glacial eustacy and low accommodation on sequence-stratigraphic interpretations of Pennsylvanian strata, Conemaugh Group, Appalachian Basin, U.S.A., in Pashin, J.C., and Gastaldo, R.A., eds., Sequence Stratigraphy, Paleoclimate, and Tectonics of Coal-bearing Strata: American Association of Petroleum Geologists Studies in Geology 51, p. 29-44. 
Nuhfer, A.T., 1979, Lateral variation in lithofacies and biofacies of the Ames Member (Conemaugh, Pennsylvanian) near Morgantown, West Virginia, unpublished Master's thesis, West Virginia University, Morgantown, 180 p.

Olszewski, T.D., and Patzkowsky, M.E., 2001, Measuring recurrence of marine biotic gradients: A case study from the Pennsylvanian-Permian midcontinent, Palaios, v. 16, p. 444-460.

O'Neill, R.V., DeAngelis, D.L., Waide, J.B., and Allen, T.H.F., 1986, A Hierarchical Concept of Ecosystems. Princeton University Press, 253 p.

Patzkowski, M.E., and Holland, S.M., 1997, Patterns of turnover in Middle and Upper Ordovician brachiopods of the eastern United States: a test of coordinated stasis, Paleobiology, v. 23, p. 420-443.

Peel, J.S., 1978, Faunal succession and mode of life of Silurian gastropods in the Arisaig Group, Nova Scotia, Palaeontology, v. 21, p. 285-306.

Posamentier, H.W., Jervey, M.T., and Vail, P.R., 1988, Eustatic controls on clastic deposition IConceptual framework, in Wilgus, C.K., Hastings, B.S., St. C. Kendall, C.G., Posamentier, H.W., Ross, C.A., and Van Wagoner, J.C., eds., Sea-level changes: an integrated approach, Society of Economic and Paleontologists and Mineralogists, Special Publication No. 42, p. 109124.

Rhodes, D.C., and Morse, J.W., 1971, Evolutionary and ecologic significance of oxygendeficient marine basins, Lethaia, v. 4, p. 413-428.

Rohlf, J.F., 1998, Numerical taxonomy and multivariate analysis system user guide. Applied Biostatistics. Exeter Software, 31 p.

Rollins, H.B., and Donahue, J., 1975, Towards a theoretical basis of paleoecology: concepts of community dynamics: Lethaia, v. 8, p. 255-270.

Rollins, H.B., Carothers, M., and Donahue, J., 1979, Transgression, regression, and fossil community succession: Lethaia, v. 12, p. 89-104.

Rouse, G. W., and Pleijel, F., 2001, Polychaetes, Oxford University Press, 354 p.

Saltsman, A.L., 1986, Paleoenvironments of the Upper Pennsylvanian Ames Limestone and associated rocks near Pittsburgh, Pennsylvania, Geological Society of America Bulletin 97, p. 222-231.

Sanchez, T.M., Carrera, M.G., Waisfeld, B.G., 2002, Hierarchy of factors controlling faunal distribution: A case study from the Ordovician of the Argentine Precordillera, Palaios, v. 17, p. 309-326.

Sanders, H. L. 1968, Marine benthic diversity: a comparative study, American Naturalist, v. 
102, p. 243-282.

SAS User's Guide, 2004, Statistics. SAS Publishing, 352 p.

Savrda, C.E., and Bottjer, D.J., 1991, Oxygen-related biofacies in marine strata: an overview and update, in Tyson, R.V., and Pearson, T.H., eds., Modern and Ancient Continental Shelf Anoxia, Geological Society of London Special Publication 58, pp. 201-219.

Schwimmer, B.A., and Sandy, M.R., 1996, Phylum Brachiopoda, in Feldmann, R. M. and Hackathorn, M., eds., Ohio Fossils. Geological Survey of Ohio Bulletin 70, p. 210-224.

Shaak, G. D., Species diversity and community structure of the Brush Creek marine interval, unpublished Ph.D. dissertation, University of Pittsburgh, Pittsburgh, PA, 105 p.

Smyth, P., 1974, Fusulinids of the Appalachian Basin, Journal of Paleontology, v. 4, p. 856-858.

Sokal, R.R., and Rohlf, F.J., 1981, Biometry. Freeman, 859 p.

Springer, D.A., and Bambach, R.K., 1985, Gradient versus cluster analysis of fossil assemblages: a comparison from the Ordovician of southwestern Virginia, Lethaia, v. 18, p. 181-198.

Stanley, S.M., 1970, Relation of shellform to life habits of the Bivalvia (Mollusca): Geological Society of America Memoir 25, 269 p.

Stanley, S.M., 1972, Functional morphology and evolution of byssally attached bivalve mollusks, Journal of Paleontology, v. 46, p. 165-212.

Stanley, S.M., and Powell, M.G., 2003, Depressed rates of origination and extinction during the Late Paleozoic ice age: A new state for the global marine ecosystem, Geology, v. 31, p. 887-880.

Stevens, C.H., 1971, Distribution and diversity of Pennsylvanian marine faunas relative to water depth and distance from shore, Lethaia, v. 4, p. 403-412.

Sturgeon, M.T. and Hoare, R.D., 1968, Pennsylvanian Brachiopods of Ohio, Geological Survey of Ohio Bulletin 63, 95 p.

Thayer, C. W., 1986, Are brachiopods better than bivalves? Mechanisms of turbidity tolerance and their interaction with feeding in articulates, Paleobiology, v. 12, p. 161-174.

Vail, P.R., Mitchum, R.M., Jr., and Thompson, S., III, 1977, Seismic stratigraphy and global changes in sea level (part 4), in Payton, C.E., ed., Seismic Stratigraphy-Application to Hydrocarbon Exploration, American Association of Petroleum Geologists Memoir 26, p. 83-97.

Valentine, J.W., 1971, Evolutionary paleoecology of the marine biosphere. Prentice Hall, 511 p.

Van Wagoner, J.C., Mitchum, R.M., Campion, K.M., and Rahmanian, V.D., 1990, Siliclastic 
sequence stratigraphy in well logs, cores, and outcrops: concepts for high-resolution correlation of time and facies, American Association of Petroleum Geologists, Methods in Exploration Series 7, $55 \mathrm{p}$.

Veevers, J.J., and Powell, M.C., 1987, Late Paleozoic glacial episodes in Gondwanaland reflected in transgressive-regressive depositional sequences in Euramerica, Geological Society of America Bulletin 98, p. 475-487.

Wanless, H.R., and Weller, J.M., 1932, Correlation and extent of Pennsylvanian cyclothems, Geological Society of America Bulletin 43, p. 1003-1016.

Wanless, H.R., and. Shepard, F.P., 1936, Sea level and climatic change related to Late Paleozoic cycles, Geological Society of America Bulletin 47, p. 1177-1206.

Warshauer, S.M., and Smosna, R., 1981, On minimum spanning trees and the intergradation of clusters, Mathmatical Geology, v. 13, p. 225-235.

Webster, G.D., 2003, Bibliography and Index of Paleozoic Crinoids, Coronates, and Hemistreptocrinoids 1758-1999: Geological Society of America, Special Paper 363, http://crinoid.gsajournals.org/crinoidmod

Whittaker, R.H., 1975, Communities and Ecosystems. Macmillan, 385 p.

Wignall, P.B., 1991, Model for transgressive black shales?, Geology, v. 19, p.167-170.

Wilde, G.L., 1975, Fusulinid evidence for the Pennsylvanian-Permian boundary, in Barlow, J.A., ed., The age of the Dunkard. Proceedings of the first I. C. White Memorial Symposium, West Virginia Geological and Economic Survey, Morgantown, West Virginia, p.123-141.

Wood, R., 1993, Nutrients, predation and the history of reef-building, Palaios, v. 8, p. 526-543.

Wray, J. L., 1977, Calcareous algae, Elsevier, 185 p.

Yancey, T.E., and Stevens, C.H., 1981, Early Permian fossil communities in northeastern Nevada and northwestern Utah, in Gray, J., Boucot, A.J., and Berry, W.B., eds., Communities of the Past, Hutchinson Ross Publishing Co., p. 243-269. 


\section{APPENDIX}

Percent abundance of guilds in 60 samples collected from the Glenshaw Formation in the northern Appalachian Basin. The first chart contains Glenshaw marine zone samples collected from the four geographic regions. The second chart contain Ames Member samples collected along a northwest-southeast transect. Refer to Table 2-1 and Figure 2-4 for outcrop locations and abbreviations, and Table 2-2 for guild composition.

\begin{tabular}{|c|c|c|c|c|c|c|c|c|c|c|c|c|c|c|c|c|c|c|c|c|}
\hline & 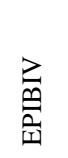 & 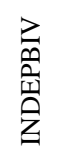 & 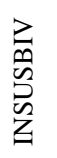 & 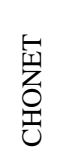 & $\begin{array}{l}\text { 疋 } \\
\text { 兄 }\end{array}$ & $\begin{array}{l}U \\
\text { Z } \\
\text { 号 } \\
\text { 空 }\end{array}$ & 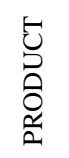 & 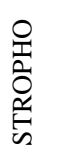 & 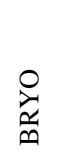 & 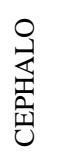 & 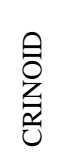 & 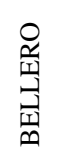 & 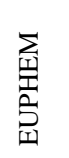 & 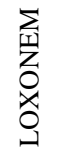 & 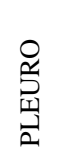 & 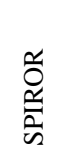 & 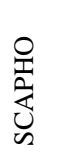 & $\begin{array}{l}\stackrel{0}{\exists} \\
\underset{\sim}{\underline{x}}\end{array}$ & 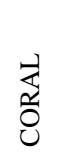 & $\mathrm{N}$ \\
\hline AMA1 & 0.0 & 0.0 & 0.0 & 6.6 & 0.0 & 0.2 & 0.0 & 0.0 & 0.0 & 0.0 & 93.1 & 0.0 & 0.0 & 0.0 & 0.0 & 0.0 & 0.0 & 0.0 & 0.0 & 40 \\
\hline AMA3 & 0.0 & 0.0 & 0.0 & 3.5 & 90.8 & 0.3 & 0.0 & 0.0 & 0.0 & 0.0 & 4.8 & 0.0 & 0.0 & 0.0 & 0.0 & 0.0 & 0.0 & 0.0 & 0.6 & 314 \\
\hline AMA5 & 0.3 & 0.3 & 0.3 & 0.0 & 96.9 & 0.0 & 0.0 & 0.0 & 0.0 & 0.0 & 2.2 & 0.0 & 0.0 & 0.0 & 0.0 & 0.0 & 0.0 & 0.0 & 0.0 & 35 \\
\hline AMH1 & 1.7 & 30.1 & 2.6 & 32.5 & 0.0 & 0.0 & 4.6 & 0.0 & 1.0 & 0.0 & 0.3 & 2.6 & 1.3 & 1.0 & 22.2 & 0.0 & 0.0 & 0.0 & 0.0 & 30 \\
\hline AMH2 & 8.2 & 6.2 & 2.3 & 10.5 & 0.0 & 0.0 & 12.4 & 1.0 & 30.7 & 0.0 & 12.7 & 1.0 & 0.0 & 1.0 & 14.1 & 0.0 & 0.0 & 0.0 & 0.0 & 30 \\
\hline АМНЗ & 0.3 & 14.1 & 0.0 & 52.8 & 0.0 & 0.0 & 1.3 & 0.0 & 0.3 & 0.7 & 0.0 & 5.2 & 1.6 & 0.0 & 23.6 & 0.0 & 0.0 & 0.0 & 0.0 & 305 \\
\hline AMH4 & 1.7 & 0.0 & 0.0 & 62.8 & 0.0 & 0.0 & 0.7 & 0.0 & 4.7 & 0.0 & 30.2 & 0.0 & 0.0 & 0.0 & 0.0 & 0.0 & 0.0 & 0.0 & 0.0 & 30 \\
\hline AMP1A & 0.0 & 0.0 & 0.0 & 1.6 & 39.0 & 1.3 & 1.6 & 0.3 & 0.0 & 0.0 & 53.2 & 0.0 & 0.0 & 0.0 & 0.0 & 0.0 & 0.0 & 0.0 & 2.9 & 310 \\
\hline AMP1B & 0.0 & 0.0 & 0.0 & 1.7 & 92.4 & 0.8 & 0.6 & 1.1 & 0.0 & 0.0 & 2.8 & 0.3 & 0.0 & 0.0 & 0.0 & 0.0 & 0.0 & 0.0 & 0.3 & 357 \\
\hline AMW1 & 0.0 & 1.3 & 1.3 & 25.3 & 38.7 & 0.0 & 1.3 & 1.3 & 0.0 & 0.7 & 21.3 & 0.0 & 0.0 & 0.0 & 8.7 & 0.0 & 0.0 & 0.0 & 0.0 & 300 \\
\hline AMW2A & 0.0 & 0.0 & 0.0 & 0.0 & 96.0 & 0.0 & 0.0 & 0.0 & 0.0 & 0.0 & 3.7 & 0.0 & 0.3 & 0.0 & 0.0 & 0.0 & 0.0 & 0.0 & 0.0 & 300 \\
\hline AMW2B & 0.0 & 11.0 & 0.3 & 0.0 & 66.9 & 0.0 & 0.0 & 0.0 & 0.0 & 0.0 & 0.0 & 0.0 & 18.5 & 1.6 & 6 & 0.0 & .0 & 0.0 & 0.0 & 308 \\
\hline AMW3 & 0.2 & 12.5 & 1.2 & 32.2 & 34.2 & 0.0 & 0.5 & 0.0 & 0.0 & 0.0 & 0.0 & 1.5 & 13.5 & 2.7 & 1.0 & 0.0 & 0.5 & 0.0 & 0.0 & 407 \\
\hline BCP1 & 5.0 & 5.3 & 0.7 & 2.7 & 2.0 & 1.7 & 0.7 & 0.0 & 0.7 & 1.3 & 77.0 & 0.0 & 0.3 & 0.3 & 2.0 & 0.0 & 0.0 & 0.0 & 0.3 & 300 \\
\hline ВСР3 & 0.3 & 4.5 & 1.6 & 0.0 & 5.8 & 0.3 & 0.0 & 0.0 & 0.0 & 5.4 & 41.9 & 10.5 & 0.0 & 1.3 & 16.3 & 0.0 & 0.3 & 0.6 & 11.2 & 313 \\
\hline BCY2A & 1.0 & 14.6 & 2.6 & 40.8 & 0.0 & 0.0 & 0.6 & 0.0 & 0.0 & 1.6 & 8.4 & 6.5 & 2.9 & 1.0 & 17.5 & 0.0 & 1.9 & 0.0 & 0.6 & 309 \\
\hline BCY2B & 1.3 & 40.3 & 5.9 & 0.0 & 0.0 & 0.0 & 0.0 & 0.0 & 0.0 & 0.0 & 22.6 & 3.0 & 4.3 & 5.6 & 16.1 & 0.0 & 1.0 & 0.0 & 0.0 & 305 \\
\hline ВСY3 & 0.0 & 0.0 & 0.3 & 2.0 & 0.0 & 1.6 & 0.0 & 0.0 & 2.0 & 3.3 & 77.1 & 10.8 & 0.0 & 0.0 & 2.9 & 0.0 & 0.0 & 0.0 & 0.0 & 306 \\
\hline САМЗВ & 1.3 & 0.3 & 0.0 & 85.0 & 0.0 & 0.0 & 0.7 & 0.0 & 0.7 & 0.0 & 7.0 & 0.0 & 0.0 & 0.0 & 5.0 & 0.0 & 0.0 & 0.0 & 0.0 & 301 \\
\hline CAMH1 & 3.0 & 2.6 & 0.3 & 73.8 & 0.0 & 0.0 & 0.3 & 0.0 & 5.6 & 0.7 & 3.6 & 2.0 & 0.0 & 3.3 & 4.9 & 0.0 & 0.0 & 0.0 & 0.0 & 305 \\
\hline CAMH2 & 4.5 & 1.3 & 0.0 & 0.0 & 0.0 & 0.0 & 5.8 & 0.0 & 25.1 & 0.3 & 62.4 & 0.0 & 0.0 & 0.0 & 0.3 & 0.0 & 0.0 & 0.3 & 0.0 & 311 \\
\hline САМНЗА & 13.5 & 4.3 & 1.5 & 1.8 & 0.0 & 3.1 & 13.5 & 0.0 & 4.3 & 0.3 & 53.8 & 1.5 & 1.2 & 0.3 & 0.9 & 0.0 & 0.0 & 0.0 & 0.0 & 327 \\
\hline LBCH2 & 0.0 & 14.5 & 2.9 & 0.0 & 0.0 & 0.0 & 0.0 & 0.0 & 0.0 & 0.0 & 0.6 & 0.0 & 7.4 & 0.6 & 5.2 & 67.1 & 1.6 & 0.0 & 0.0 & 310 \\
\hline LBCH3 & 0.0 & 1.3 & 0.0 & 36.5 & 0.0 & 0.0 & 0.0 & 0.0 & 5.6 & 1.6 & 46.1 & 7.2 & 0.0 & 0.0 & 1.0 & 0.7 & 0.0 & 0.0 & 0.0 & 304 \\
\hline LBCH4 & 4.0 & 45.5 & 4.3 & 35.2 & 0.0 & 0.0 & 0.3 & 0.0 & 0.0 & 0.0 & 0.0 & 8.3 & 2.0 & 0.0 & 0.3 & 0.0 & 0.0 & 0.0 & 0.0 & 301 \\
\hline NADY1 & 3.4 & 0.0 & 0.7 & 73.8 & 0.0 & 0.0 & 5.0 & 4.4 & 9.1 & 0.0 & 3.7 & 0.0 & 0.0 & 0.0 & 0.0 & 0.0 & 0.0 & 0.0 & 0.0 & 298 \\
\hline NADY2A & 0.0 & 5.0 & 0.0 & 1.7 & 0.3 & 0.0 & 1.3 & 0.0 & 1.0 & 0.0 & 78.3 & 6.7 & 0.0 & 2.7 & 3.0 & 0.0 & 0.0 & 0.0 & 0.0 & 300 \\
\hline NADY2B & 0.0 & 0.3 & 0.0 & 11.0 & 0.0 & 0.0 & 0.7 & 0.0 & 0.7 & 0.0 & 81.7 & 0.7 & 0.0 & 0.7 & 0.0 & 0.0 & 0.0 & 0.0 & 4.3 & 300 \\
\hline NAP1 & 0.3 & 2.1 & 0.0 & 1.3 & 9.7 & 0.3 & 0.0 & 0.0 & 5.4 & 0.0 & 80.4 & 0.5 & 0.0 & 0.0 & 0.0 & 0.0 & 0.0 & 0.0 & 0.0 & 373 \\
\hline NAP3 & 2.3 & 0.6 & 0.3 & 0.0 & 59.2 & 0.0 & 4.2 & 0.0 & 0.0 & 0.0 & 33.3 & 0.0 & 0.0 & 0.0 & 0.0 & 0.0 & 0.0 & 0.0 & 0.0 & 309 \\
\hline PCP1 & 0.0 & 9.2 & 1.0 & 0.0 & 0.0 & 0.0 & 0.0 & 0.0 & 0.0 & 0.0 & 0.0 & 0.0 & 9.2 & 71.3 & 9.2 & 0.0 & 0.0 & 0.0 & 0.0 & 314 \\
\hline PCP2 & 0.7 & 0.0 & 0.7 & 87.9 & 0.0 & 0.7 & 0.7 & 0.0 & 0.3 & 3.9 & 0.7 & 1.3 & 0.7 & 0.0 & 2.6 & 0.0 & 0.0 & 0.0 & 0.0 & $30 €$ \\
\hline РСР3 & 0.7 & 4.3 & 1.0 & 2.0 & 21.9 & 0.0 & 0.7 & 0.0 & 0.0 & 1.3 & 9.3 & 4.0 & 6.0 & 13.0 & 29.2 & 0.0 & 0.3 & 0.3 & 6.0 & 301 \\
\hline PCY1 & 0.3 & 0.0 & 0.3 & 3.0 & 1.0 & 1.3 & 0.7 & 0.0 & 0.0 & 0.0 & 92.7 & 0.0 & 0.0 & 0.0 & 0.0 & 0.0 & 0.0 & 0.7 & 0.0 & 302 \\
\hline PCY2 & 0.0 & 1.9 & 1.6 & 1.9 & 0.0 & 0.0 & 0.5 & 0.0 & 0.0 & 0.3 & 86.4 & 2.7 & 4.0 & 0.0 & 0.5 & 0.0 & 0.3 & 0.0 & 0.0 & 375 \\
\hline PCY3 & 46.3 & 4.7 & 8.3 & 0.0 & 0.0 & 0.0 & 29.0 & 0.0 & 0.0 & 0.0 & 0.0 & 3.0 & 5.3 & 3.0 & 0.3 & 0.0 & 0.0 & 0.0 & 0.0 & 300 \\
\hline UBCH2 & 0.0 & 0.0 & 0.0 & 37.1 & 0.0 & 3.9 & 0.6 & 0.0 & 31.0 & 0.0 & 27.4 & 0.0 & 0.0 & 0.0 & 0.0 & 0.0 & 0.0 & 0.0 & 0.0 & 310 \\
\hline
\end{tabular}




\begin{tabular}{|c|c|c|c|c|c|c|c|c|c|c|c|c|c|c|c|c|c|c|c|c|}
\hline & 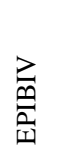 & 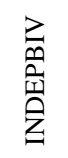 & 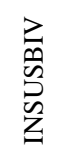 & 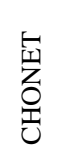 & $\begin{array}{l}\overrightarrow{\widetilde{S}} \\
\text { 兄 }\end{array}$ & 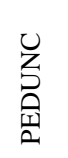 & 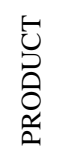 & 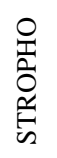 & 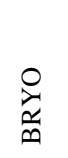 & 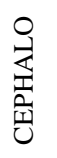 & 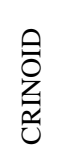 & 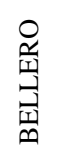 & 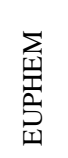 & 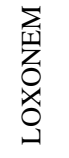 & 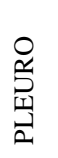 & 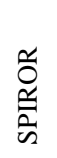 & 怘 & 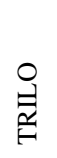 & 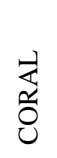 & $\mathrm{N}$ \\
\hline ANMO1 & 0.0 & 3.7 & 0.6 & 55.6 & 0.0 & 0.0 & 0.0 & 0.0 & 0.0 & 0.0 & 0.0 & 2.8 & 5.3 & 28.9 & 1.9 & 0.0 & 1.2 & 0.0 & 0.0 & 322 \\
\hline ANMO2 & 0.0 & 4.3 & 0.0 & 19.9 & 0.0 & 0.0 & 0.0 & 0.0 & 0.0 & 0.0 & 0.0 & 3.1 & 3.7 & 63.4 & 4.7 & 0.0 & 0.9 & 0.0 & 0.0 & 322 \\
\hline ANMO3 & 0.7 & 4.2 & 0.0 & 80.1 & 0.0 & 0.0 & 11.4 & 0.0 & 0.0 & 0.0 & 2.6 & 0.0 & 0.0 & 1.0 & 0.0 & 0.0 & 0.0 & 0.0 & 0.0 & 306 \\
\hline ANMO4 & 0.3 & 26.9 & 7.0 & 0.0 & 0.0 & 0.0 & 0.3 & 0.0 & 0.0 & 0.0 & 0.0 & 4.0 & 40.2 & 14.0 & 6.3 & 0.0 & 1.0 & 0.0 & 0.0 & 301 \\
\hline BELL2 & 0.0 & 1.0 & 0.0 & 93.1 & 1.0 & 0.0 & 0.0 & 0.0 & 1.0 & 0.7 & 1.3 & 0.0 & 0.0 & 0.0 & 2.0 & 0.0 & 0.0 & 0.0 & 0.0 & 304 \\
\hline BELL3 & 0.0 & 0.0 & 0.0 & 44.7 & 0.9 & 0.0 & 4.5 & 0.0 & 11.1 & 0.0 & 37.2 & 0.0 & 0.0 & 0.0 & 1.5 & 0.0 & 0.0 & 0.0 & 0.0 & 333 \\
\hline BELL5 & 0.0 & 0.7 & 0.0 & 5.7 & 14.5 & 5.7 & 0.7 & 0.0 & 3.0 & 0.0 & 68.2 & 0.0 & 0.0 & 0.0 & 1.4 & 0.0 & 0.0 & 0.0 & 0.0 & 296 \\
\hline BELN1 & 1.0 & 2.3 & 0.3 & 77.9 & 0.0 & 0.0 & 0.0 & 0.0 & 0.0 & 0.7 & 0.0 & 1.0 & 2.3 & 12.4 & 2.3 & 0.0 & 0.0 & 0.0 & 0.0 & 307 \\
\hline BELN2 & 0.0 & 17.0 & 21.3 & 0.0 & 0.0 & 0.0 & 0.0 & 0.0 & 0.0 & 0.0 & 0.0 & 32.0 & 8.7 & 19.7 & 1.3 & 0.0 & 0.0 & 0.0 & 0.0 & 300 \\
\hline CONC & 2.6 & 0.0 & 0.0 & 10.2 & 0.7 & 3.0 & 9.5 & 0.0 & 0.3 & 0.0 & 72.4 & 1.0 & 0.0 & 0.0 & 0.3 & 0.0 & 0.0 & 0.0 & 0.0 & 304 \\
\hline FAIR1A & 0.0 & 3.6 & 0.3 & 74.0 & 4.6 & 0.0 & 0.0 & 3.0 & 0.0 & 0.0 & 1.0 & 1.3 & 3.0 & 7.2 & 2.0 & 0.0 & 0.0 & 0.0 & 0.0 & 304 \\
\hline FAIR1B & 0.0 & 12.7 & 0.0 & 8.2 & 0.0 & 0.0 & 0.0 & 0.0 & 0.0 & 0.0 & 0.0 & 2.1 & 4.1 & 68.5 & 3.4 & 0.0 & 1.0 & 0.0 & 0.0 & 292 \\
\hline FAIR2 & 0.0 & 1.0 & 0.0 & 37.5 & 0.0 & 0.0 & 0.0 & 0.0 & 0.0 & 0.0 & 0.3 & 2.3 & 0.7 & 53.4 & 3.9 & 0.0 & 1.0 & 0.0 & 0.0 & 307 \\
\hline FAIR3 & 0.0 & 1.6 & 0.6 & 88.8 & 0.0 & 0.0 & 0.0 & 0.0 & 0.0 & 4.7 & 0.0 & 1.6 & 0.6 & 0.3 & 1.9 & 0.0 & 0.0 & 0.0 & 0.0 & 321 \\
\hline FAIR4 & 0.0 & 67.6 & 0.0 & 0.0 & 23.2 & 0.0 & 0.0 & 0.0 & 0.0 & 0.7 & 0.0 & 1.3 & 4.2 & 1.6 & 1.3 & 0.0 & 0.0 & 0.0 & 0.0 & 306 \\
\hline FAIR5 & 2.2 & 32.2 & 2.5 & 8.5 & 36.3 & 0.0 & 2.5 & 0.0 & 0.0 & 3.5 & 0.0 & 0.6 & 2.8 & 6.0 & 2.2 & 0.0 & 0.6 & 0.0 & 0.0 & 317 \\
\hline GRR5A & 0.0 & 4.8 & 0.0 & 79.6 & 8.0 & 0.0 & 1.7 & 0.0 & 0.0 & 1.1 & 0.4 & 1.5 & 0.7 & 0.2 & 2.0 & 0.0 & 0.0 & 0.0 & 0.0 & 538 \\
\hline GRR5B & 0.0 & 1.3 & 0.0 & 92.9 & 4.2 & 0.0 & 0.0 & 0.3 & 0.0 & 0.3 & 0.3 & 0.0 & 0.3 & 0.0 & 0.3 & 0.0 & 0.0 & 0.0 & 0.0 & 308 \\
\hline GRR6A & 0.0 & 44.4 & 0.0 & 1.6 & 38.1 & 0.0 & 0.0 & 0.0 & 0.0 & 1.9 & 0.0 & 4.7 & 4.4 & 0.0 & 2.8 & 0.0 & 2.2 & 0.0 & 0.0 & 320 \\
\hline GRR6B & 0.3 & 63.0 & 0.0 & 0.3 & 8.6 & 0.0 & 0.0 & 0.0 & 0.0 & 0.0 & 0.0 & 0.3 & 17.7 & 3.1 & 6.8 & 0.0 & 0.0 & 0.0 & 0.0 & 384 \\
\hline GRR9A & 0.0 & 0.0 & 0.0 & 89.7 & 5.2 & 2.6 & 1.9 & 0.6 & 0.0 & 0.0 & 0.0 & 0.0 & 0.0 & 0.0 & 0.0 & 0.0 & 0.0 & 0.0 & 0.0 & 310 \\
\hline GRR9B & 0.0 & 0.9 & 0.0 & 0.0 & 0.0 & 79.4 & 18.9 & 0.3 & 0.6 & 0.0 & 0.0 & 0.0 & 0.0 & 0.0 & 0.0 & 0.0 & 0.0 & 0.0 & 0.0 & 339 \\
\hline NEW1 & 2.6 & 3.7 & 5.4 & 56.7 & 0.6 & 0.9 & 0.9 & 6.0 & 0.9 & 0.3 & 11.2 & 0.0 & 3.7 & 6.6 & 0.6 & 0.0 & 0.0 & 0.0 & 0.0 & 349 \\
\hline
\end{tabular}




\section{VITA}

Born: August 11, 1972, Springfield, Ohio

B.S. Geology, 1994, West Virginia University, Morgantown, WV

M.S. Geology, 1998, Ohio State University, Columbus, OH

2001-2005, Instructor, Graduate Student, and Teaching Associate, West Virginia University, Morgantown, WV 